\title{
Enargite-luzonite hydrothermal vents in Manus Back-Arc Basin: submarine analogues of high-sulfidation epithermal mineralization
}

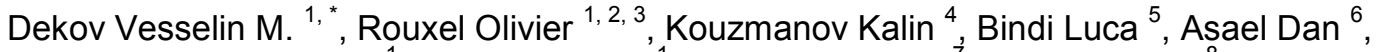 \\ Fouquet Yves ${ }^{1}$, Etoubleau Joel ${ }^{1}$, Burgaud Gaëtan ${ }^{7}$, Wälle Markus ${ }^{8}$
}

${ }^{1}$ Department of Marine Geosciences, IFREMER, 29280 Plouzané, France

${ }^{2}$ Marine Chemistry and Geochemistry Department, Woods Hole Oceanographic Institution, Woods Hole, MA 02543, USA

${ }^{3}$ Department of Oceanography, School of Ocean and Earth Science and Technology, University of Hawaii at Manoa, 1000 Pope Road, MSB 510, Honolulu, HI 96822, USA

${ }^{4}$ Department of Earth Sciences, University of Geneva, rue des Maraichers 13, CH-1205 Geneva, Switzerland

${ }^{5}$ Dipartimento di Scienze della Terra, Università degli Studi di Firenze, Via Giorgio La Pira 4, I-50121

Firenze, Italy

${ }^{6}$ Department of Geology and Geophysics, Yale University, New Haven, CT 06520, USA

${ }^{7}$ Laboratoire Universitaire de Biodiversité et Ecologie Microbienne (EA3882), IFR 148, Université

Européenne de Bretagne, Université de Brest, ESIAB, Technopôle Brest-Iroise, 29280 Plouzané,

France

${ }^{8}$ Institute of Geochemistry and Petrology, ETH Zurich, Clausiusstrasse 25, CH-8092 Zurich, Switzerland

*Corresponding author : Vesselin M. Dekov, email address : Vesselin.Dekov@ifremer.fr

\begin{abstract}
:
Active and inactive hydrothermal chimneys composed almost entirely of enargite and luzonite, rare minerals in seafloor hydrothermal deposits, were found at the summits of two submarine volcanoes, North Su and Kaia Natai, in the Manus Back-Arc Basin. Detailed mineralogical and geochemical studies revealed that most probably these deposits precipitated at $\mathrm{T}=200^{\circ}-330^{\circ} \mathrm{C}$ and high fS2. The negative $\delta 34 \mathrm{~S}$ values $(-8.58$ to $-3.70 \%$ ) of the enargite-luzonite are best explained by disproportionation reactions of magmatic SO2 and suggest that the high fS2 is likely provided by direct magmatic input of $\mathrm{SO} 2$ into the hydrothermal system. Fractionation of $\mathrm{Cu}$ stable isotopes during the precipitation of enargite-luzonite $(\delta 65 \mathrm{Cu}$ ranges from -0.20 to $+0.35 \%$ ) is inferred to be associated with either Rayleigh-type fractionation, or redox processes ( $\mathrm{Cu}+$ oxidation to $\mathrm{Cu} 2+)$ and the mass balance of dissolved $\mathrm{Cu}+$ and $\mathrm{Cu} 2+$ species in the hydrothermal fluid. The trace element composition of enargite and luzonite indicates a temporal fluctuation of the chemistry of the ore-forming fluid with an increase of $\mathrm{Fe}, \mathrm{Ga}, \mathrm{Tl}, \mathrm{Au}, \mathrm{Hg}, \mathrm{Pb}$ and $\mathrm{Ag}$, and decrease of $\mathrm{Sb}, \mathrm{Sn}, \mathrm{Te}, \mathrm{Ge}$ and $\mathrm{V}$ concentrations with time and points out that this type of deposits is the richest in Au (average $11.9 \mathrm{ppm}$ ) and Te (average $169 \mathrm{ppm}$ ) among all other types of seafloor metal deposits.
\end{abstract}


In addition to the widespread inorganic precipitation of enargite and luzonite in this setting, there is evidence that this mineralization may be biogenically mediated on the external surfaces of the active vents. Fungi-like filaments mineralized by luzonite imply that the fungi (Dikarya subkingdom) may be implicated in a mechanism of bio-sequestration of $\mathrm{As}, \mathrm{S}$ and $\mathrm{Cu}$, and provide the initial substrate for luzonite precipitation.

The studied enargite-luzonite deposits have characteristics similar to those of subaerial high-sulfidation epithermal mineralization: back-arc basin setting; acid-sulfate and boiling ore-forming fluids; altered (advanced argillic stage) dacitic host rocks; major enargite-luzonite and minor pyrite, barite and S0; $\delta 34 \mathrm{~S}<0 \%$. Therefore, they may be considered as submarine analogues of subaerial high-sulfidation epithermal deposits with the potential for concealed porphyry $\mathrm{Cu}($ single bondAu) mineralization at depth.

\section{Highlights}

- Active and inactive hydrothermal chimneys composed of enargite and luzonite form in a back-arc basin; These deposits precipitated at $\mathrm{T}=200^{\circ}-330^{\circ} \mathrm{C}$ and high $\mathrm{fS}_{2}$; They are the richest in $\mathrm{Au}$ and Te among all other types of seafloor metal deposits; They may be considered as submarine analogues of subaerial high-sulfidation epithermal deposits; Fungi may be implicated in a mechanism of bio-sequestration of $\mathrm{As}, \mathrm{S}$ and $\mathrm{Cu}$, and provide substrate for Luzonite precipitation.

Keywords : Enargite, Epithermal, Hydrothermal vent, Luzonite, S-Cu isotopes, Seafloor 


\section{Introduction}

The mineralogical composition of seafloor hydrothermal deposits has been increasingly well characterized (e.g., Haymon and Kastner, 1981; Oudin, 1983; Koski et al., 1984; Fouquet et al., 1988; Koski et al., 1988; Hannington et al., 1991; Fouquet et al., 1993a, b; Iizasa et al., 1999; Rouxel et al., 2004a; Fouquet et al., 2010; Webber et al., 2015). Although these investigations recognize distinct mineralogical differences among hydrothermal deposits formed at mid-ocean ridges (MOR) (sedimented and unsedimented), volcanic arcs and back-arc spreading centers, they show that most seafloor hydrothermal deposits are composed of relatively simple mineral assemblages. Iron-, $\mathrm{Cu}$ - and $\mathrm{Zn}$-sulfides, and $\mathrm{Ca}$ - and $\mathrm{Ba}$-sulfates are the main constituents of these deposits, whereas silicates, oxyhydroxides, carbonates and sulfosalts are minor phases (Herzig and Hannington, 1995). Therefore, hydrothermal chimneys and mounds composed almost entirely of one mineral considered to be minor in seafloor hydrothermal deposits, like native sulfur (Chen et al., 2005), silica (Herzig et al., 1988) or talc (Hodgkinson et al., 2015), attract special scientific interest because this type of deposits testifies for uncommon conditions of precipitation $\left(\mathrm{T}, \mathrm{P}, \mathrm{pH}\right.$, Eh, ion activity and speciation) over time. Enargite $\left(\mathrm{Cu}_{3} \mathrm{AsS}_{4}\right)$ and its polymorph luzonite are minor minerals in seafloor hydrothermal deposits mainly reported from volcanic arc and back-arc settings (Halbach et al., 1993; Lüders et al., 2001; Dekov and Savelli, 2004; Petersen et al., 2004; Rouxel et al., 2004b; de Ronde et al., 2005; Suzuki et al., 2008; Fouquet et al., 2010; Alfieris et al., 2013; Petersen et al., 2014).

We investigated the mineralogy and geochemistry (including $\mathrm{S}$ - and $\mathrm{Cu}$-isotope composition) of active and inactive hydrothermal vents composed almost entirely of the $\mathrm{Cu}$ sulphosalt (enargite-luzonite) assemblage from a back-arc basin (BAB) setting and address their conditions of precipitation and potential importance in terms of both the genesis and mineral exploration of seafloor hydrothermal deposits.

\section{Geologic setting}

Hydrothermal deposits were recovered from two seafloor hydrothermal fields (North $\mathrm{Su}$ and Kaia Natai) situated in an intra-oceanic back-arc spreading setting: East Manus Basin (Fig. 1, Table 1). The Manus Back-Arc Basin is structurally bound by the inactive Manus-Kilinailau and active New Britain subduction zones and floored by North and South Bismarck microplates (Fig. 1). The active spreading in the Manus Basin occurs at three successive ridge segment offsets by 
the Willaumez, Djaul and Weitin transform faults (from west to east) (Fig. 1). Recent hydrothermal activity has been documented at the Manus spreading center and in the East Manus Basin (Scott and Binns, 1995; Bach et al., 2003; Roberts et al., 2003; Vanko et al., 2004; Binns, 2006; Binns et al., 2007; Craddock et al., 2010; Reeves et al., 2011). East Manus Basin (between the Djaul and Weitin transform faults) is an active transform zone within island-arc crust formed during previous subduction of the Pacific Plate under the New Ireland Arc (Taylor, 1979; Binns and Scott, 1993; Martinez and Taylor, 1996). Magmatic activity associated with the incipient rifting of felsic crust has produced a series of volcanic ridges composed of a wide range of lavas (from basalts to rhyodacites) showing strong geochemical arc affinities (Binns and Scott, 1993; Sinton et al., 2003). Several large hydrothermal systems have been discovered in the East Manus Basin (Binns and Scott, 1993; Scott and Binns, 1995; Gamo et al., 1997; Ishibashi et al., 1997; Bach et al., 2003; Roberts et al., 2003; Vanko et al., 2004; Binns, 2006; Binns et al., 2007; Craddock et al., 2010; Reeves et al., 2011). Three porphyritic dacite domes, known as the $\mathrm{SuSu}$ Knolls comprising three vent fields (Suzette, North $\mathrm{Su}$ and South $\mathrm{Su}$ ), are situated in the East Manus Basin. The middle seamount of this series, North Su, is hydrothermally active with many black and white smokers, diffuse venting and numerous relict chimneys (Fig. 1). Kaia Natai is another submarine volcano, which is situated $\sim 10 \mathrm{~km}$ east of the $\mathrm{SuSu}$ Knolls (Fig. 1). An inactive hydrothermal field covers its summit and upper part of the southeastern slope.

\section{Samples and methods of investigation}

\subsection{Samples}

We investigated three samples consisting dominantly of enargite and luzonite from three vent sites at two seafloor hydrothermal fields: North Su and Kaia Natai (Table 1). The samples were collected during the R/V L'Atalante cruise Manaute (2000) using the Deep Submersible Vehicle (DSV) Nautile (two samples) and during the R/V Melville cruise MGLN06MV (2006) using the Remotely Operated Vehicle (ROV) Jason (one sample) (Table 1). One of the samples was a part of an active flange with pooled fluid (buoyant hydrothermal fluid entrapped beneath the flange, underlain by colder and denser seawater) with a temperature of $212^{\circ} \mathrm{C}$ (Fig. $2 \mathrm{~A}$ ), 
whereas the other two samples were massive sulfide-sulfosalt-sulfate slabs collected around inactive chimneys (Table 1).

\subsection{Methods of investigation}

\subsubsection{Mineralogy and mineral chemistry analyses}

After preliminary investigation with a stereo-microscope (WILD M8), sub-samples were prepared as polished sections and their mineralogy and textures investigated using an Olympus BX60 polarizing transmitted and reflected light microscope. Based on the macroscopic heterogeneity, the sample from the active flange wall (J2-223-13-R1) was divided into two subsamples: $\mathbf{a}=$ internal layer, and $\mathbf{b}=$ external layer (Fig. 2 B).

Secondary electron images (SEI) and energy dispersive X-ray spectra (EDS) were obtained on small $(\sim 0.5 \times 0.5 \mathrm{~cm})$ sub-samples, mounted on aluminum stubs using carbon tape and coated with $\mathrm{Au}$ using a FEI Quanta 200 scanning electron microscope $(\mathrm{SEM})(\mathrm{V}=10 \mathrm{kV}, \mathrm{I}=100 \mu \mathrm{A}$, electron beam diameter of $2 \mu \mathrm{m})$.

Electron microprobe analyses (EMPA) and elemental X-ray mapping were carried out using a Jeol JXA 8200 Superprobe WD/ED combined microanalyzer. Operating conditions were: $\mathrm{V}=25 \mathrm{kV}, \mathrm{I}=25 \mathrm{nA}$, and electron beam diameter of $1 \mu \mathrm{m}$. Standards and radiations used were as follows: $\mathrm{FeS}_{2}(\mathrm{Fe}-K \alpha, \mathrm{S}-K \alpha), \mathrm{GaAs}(\mathrm{As}-L \alpha), \mathrm{Sb}_{2} \mathrm{~S}_{3}(\mathrm{Sb}-L \alpha), \mathrm{Cu}_{5} \mathrm{FeS}_{4}(\mathrm{Cu}-K \alpha), \mathrm{CdSe}(\mathrm{Se}-L \alpha)$, $\operatorname{MnS}(\mathrm{Mn}-K \alpha), \mathrm{ZnS}(\mathrm{Zn}-K \alpha), \operatorname{SnS}(\mathrm{Sn}-L \alpha)$, Te metal (Te-L $\alpha)$ and Ag metal (Ag- $L \alpha)$. Counting times of $20 \mathrm{~s}$ on peak and $10 \mathrm{~s}$ on background on both sides of the peak were used for all elements. Limits of detections (LOD) were calculated as the minimum concentration required to produce count rates three times higher than the square root of the background $(3 \sigma ; 99 \%$ degree of confidence on the lowest detection limit). Overlap and matrix corrections were carried out following the established protocol and software in the laboratory (University of Lausanne).

Laser-ablation inductively-coupled plasma mass-spectrometry (LA-ICP-MS) analyses of enargite, luzonite and pyrite/marcasite were conducted using a $193 \mathrm{~nm}$ ArF Excimer laser with an energy homogenized beam profile coupled with an ELAN 6100 DRC ICP quadrupole mass spectrometer (QMS) (Günther et al., 1997; Heinrich et al., 2003). A summary of the analytical conditions and data acquisition parameters used during LA-ICP-MS sessions is provided in Appendix 1. The ablation rate for enargite and luzonite was between 0.1 and $0.2 \mu \mathrm{m} / \mathrm{pulse}$. The 
optical imaging system allows precise visual positioning of ablation spots and the use of different pit diameters $(50-60 \mu \mathrm{m})$ at constant energy density on the sample, by adjusting an aperture in the laser beam path. The samples were loaded along with the synthetic polymetallic sulfide standard MASS-1 (Wilson et al., 2002) and the SRM 610 glass NIST standard in a $1 \mathrm{~cm}^{3}$ ablation cell on a modified Zeiss petrographic microscope. Data reduction was carried out using the SILLS software (Guillong et al., 2008) and using the $\mathrm{Cu}$ content, from electron microprobe analyses, as an internal standard for enargite and luzonite and Fe content for pyrite/marcasite.

The bulk mineralogical composition of the finely powdered sub-samples was determined by X-ray diffraction (XRD) analysis (Philips X-ray diffractometer PW 1820 with monochromatic Co $K_{\alpha}$ radiation) of random mounts with scans from 4 to $75^{\circ} 2 \theta$, with $0.02^{\circ} 2 \theta$ step, and 1 s/step. XRD patterns were interpreted by using the XPowder® software. The unit-cell parameters for enargite and luzonite from the selected samples were calculated.

\subsubsection{Bulk geochemical analyses}

Concentrations of $\mathrm{S}, \mathrm{Si}, \mathrm{Al}, \mathrm{Mg}, \mathrm{K}, \mathrm{Ti}$ and $\mathrm{P}$ in the bulk samples were determined by wavelength dispersive X-ray-fluorescence (WD-XRF) spectrometry (S8 Bruker) on fused disks prepared in the following way. $0.2 \mathrm{~g}$ sample (dry powder) were placed over $6 \mathrm{~g}$ spectroflux 161 $\left(\mathrm{Li}_{2} \mathrm{~B}_{4} \mathrm{O}_{7} 90 \%+\mathrm{LiNO}_{3} 10 \%\right.$; Johnson Matthey) in an Au-Pt crucible with particular care to avoid any contact with the inner surface of the crucible. $0.2 \mathrm{~g} \mathrm{NaBr}$ was added and covered successively with $2 \mathrm{~g}$ spectroflux 161 and $3 \mathrm{~g}$ spectroflux $106\left(\mathrm{Li}_{2} \mathrm{~B}_{4} \mathrm{O}_{7} 85 \%+\mathrm{La}_{2} \mathrm{O}_{3} \quad 15 \%\right.$; Johnson Matthey). The crucible was heated from ambient temperature to $500^{\circ} \mathrm{C}$ for $1 \mathrm{~h}$ (oxidation) and then to $1000^{\circ} \mathrm{C}$ (fusion) in an electric furnace. The melt was homogenized and heated again at $1000^{\circ} \mathrm{C}$ for $5 \mathrm{~min}$. This preparation provides a homogenous glass disk and avoids sample homogeneity and grain size effects. The presence of an oxidizing agent $\left(\mathrm{LiNO}_{3}\right)$ prevents losses of $\mathrm{S}$ during the fusion. Concentrations of $\mathrm{Ba}$ and $\mathrm{Ag}$ were determined by the same method on pressed pellet powder. Element line intensities corrected for matrix effects and overlaps were correlated with the lines of a set of certified reference materials (CRM) to elaborate linear calibration curves. CRM were obtained from the Canadian Certified Reference Materials: CCU-1 set $(\mathrm{Cu}$ concentrates); $\mathrm{CZN}-1$ set ( $\mathrm{Zn}$ concentrates); KC-1a, PTC-1a (noble metals-bearing sulfide ore concentrate); PTM-1a (noble metals-bearing Ni-Cu sulfide ore concentrate); RTS-1, 2, -3 (sulfide ore tailings); MP-1, MP-2, WMS-1a (massive sulfide). 
Concentrations of Fe, Cu, As, Sb, Zn, Pb, Ni, V, Cr, Mn, Ca, Co, Se, S, Ba, Mo, Cd, In, Sn, $\mathrm{Te}, \mathrm{Au}, \mathrm{Tl}, \mathrm{Bi}$ and U were measured by Inductively Coupled Plasma-Mass Spectrometry (ICPMS) (X-series Thermo Scientific) after digestion of the bulk samples according to the following procedure. About $100 \mathrm{mg}$ of each sample (finely powdered) were dissolved with $5 \mathrm{~mL}$ doubledistilled concentrated $\mathrm{HNO}_{3}$ in $30 \mathrm{~mL}$ Teflon vials. The solutions were evaporated to dryness on a hot $\left(90^{\circ} \mathrm{C}\right)$ plate. The residues were dissolved with $5 \mathrm{~mL}$ double-distilled concentrated $\mathrm{HNO}_{3}$ and $5 \mathrm{~mL}$ of $6 \mathrm{~mol} / \mathrm{L} \mathrm{HCl}$, and evaporated to dryness on a hot $\left(90^{\circ} \mathrm{C}\right)$ plate. The residues were dissolved with $5 \mathrm{~mL}$ of $6 \mathrm{~mol} / \mathrm{L} \mathrm{HCl}$ with $10 \mu \mathrm{L}$ of $30 \% \mathrm{H}_{2} \mathrm{O}_{2}$ and stored in $15 \mathrm{~mL}$ Low Density Polyethylene (LDPE) bottles. Before elemental concentration measurements, $1 \mathrm{~mL}$ of these solutions were evaporated to dryness in Teflon vials on a hot $\left(90^{\circ} \mathrm{C}\right)$ plate and redissolved in 3

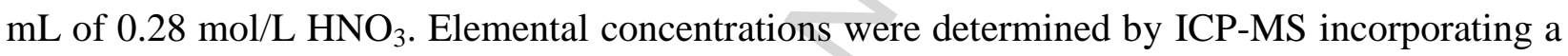
collision cell that suppresses isobaric interferences from argide species on As and Se. The ICPMS instrument was calibrated using a set of multi-elemental standard solutions matching typical sulfide matrices.

\subsubsection{Cu isotope analysis}

A separate set of solutions was prepared for $\mathrm{Cu}$-isotope analysis of all the four bulk samples. In order to investigate the $\mathrm{Cu}$-isotope spatial variations in a single sample we collected 13 powder micro-samples along two transects (six and seven sampling points, respectively) across the sample J2-223-13-R1 (active flange wall, prepared as a polished section) using a MicroMill device (New Wave Research) equipped with a tungsten-carbide drill bit $(0.7 \mathrm{~mm}$ diameter). These micro-samples were digested in a similar way as the bulk samples. All digested samples were purified through a three-step anion-exchange chromatography procedure modified from that of Maréchal et al. (1999) and Borrok et al. (2007). In general, our protocol consisted of elution of matrix elements and separation of $\mathrm{Cu}$ from Fe using AG MP-1M resin (2 mL wet volume) after its careful washing and conditioning to appropriate acid solutions.

Step 1. After the samples $\left(1 \mathrm{~mL}\right.$ in $\left.10 \mathrm{~mol} / \mathrm{L} \mathrm{HCl}+10 \mu \mathrm{L} \mathrm{H}_{2} \mathrm{O}_{2}\right)$ had been loaded on the resin, the matrix was eluted in $6.5 \mathrm{~mL}$ of $10 \mathrm{~mol} / \mathrm{L} \mathrm{HCl}$.

Step 2. $\mathrm{Cu}$ was eluted and separated from $\mathrm{Fe}$ in $16 \mathrm{~mL}$ of $5 \mathrm{~mol} / \mathrm{L} \mathrm{HCl}$ in Teflon vials, evaporated $\left(90^{\circ} \mathrm{C}\right)$ to dryness and the residue was dissolved in $3 \mathrm{~mL}$ of $\sim 0.28 \mathrm{~mol} / \mathrm{L} \mathrm{HNO}_{3}$. 
Step 3. Fe and the other elements remaining on the resin (e.g., Zn, Cd) were further eluted in $14 \mathrm{~mL}$ of $1.2 \mathrm{~mol} / \mathrm{L} \mathrm{HCl}$ and $14 \mathrm{~mL}$ of $0.0012 \mathrm{~mol} / \mathrm{L} \mathrm{HCl}$ in Teflon vials, respectively, the solutions were evaporated $\left(90^{\circ} \mathrm{C}\right)$ to dryness, the residues were dissolved in $3 \mathrm{~mL}$ of $\sim 0.28 \mathrm{~mol} / \mathrm{L}$ $\mathrm{HNO}_{3}$ and stored for further analyses.

Blanks and multi-element standards (prepared from mono-element Spex standard solutions) were included in the sample set and subjected to the same anion-exchange chromatography procedure. Blanks yielded less than $10 \mathrm{ng}$ of $\mathrm{Cu}$, which is negligible compared to the amount of $\mathrm{Cu}$ processed through the anion-exchange chromatography columns (typically more than 500 $\mu \mathrm{g})$. The chemistry yield was quantitative and determined for all the sample batches using a set of internal standards processed through the entire chemical procedure.

${ }^{65} \mathrm{Cu} /{ }^{63} \mathrm{Cu}$ measurements were made on a Multi-Collector Inductively Coupled Plasma Mass Spectrometer (MC-ICP-MS) (Neptune Thermo Scientific) operating at low resolution. The samples were introduced into the plasma using a double spray quartz chamber system (cyclonic and double pass) and a microconcentric PFA nebulizer operating at a flow rate of about $60 \mu \mathrm{L}$ $\min ^{-1}$. Instrumental mass bias was corrected for using $\mathrm{Zn}$ isotopes as an internal standard and involved simultaneous measurement of a Zn standard solution (NIST-SRM 3168a Standard Solution). Also a standard bracketing approach, which normalizes the $\mathrm{Cu}$ isotope ratio to the average measured composition of a standard (NIST-SRM 976) was carried out before and after each sample.

$\mathrm{Cu}$-isotope ratios are reported relative to the measured ratio for a $\mathrm{Cu}$-isotope standard (NIST-SRM 976) as follows:

$$
\delta^{65} \mathrm{Cu}=\left(\mathrm{R}_{\text {sample }} / \mathrm{R}_{\text {standard }}-1\right) \times 1000,
$$

where $\mathrm{R}_{\text {sample }}$ is the measured ${ }^{65} \mathrm{Cu} /{ }^{63} \mathrm{Cu}$ ratio for the unknown sample and $\mathrm{R}_{\text {standard }}$ is the mean ${ }^{65} \mathrm{Cu} /{ }^{63} \mathrm{Cu}$ ratio of the NIST-SRM 976 (corrected using $\mathrm{Zn}$ external normalization) measured before and after the sample. Standard deviation values (2SD) were calculated according to the reproducibility of the duplicated standard analysis (NIST-SRM 3119) obtained during the whole analytical session, and ranged from 0.02 to 0.03 per mil.

\subsubsection{S isotope analysis}

Splits of the sample solutions used for multi-elemental concentration measurements and bulk $\mathrm{Cu}$-isotope analysis were analyzed for $\mathrm{S}$ isotopes $\left(\delta^{34} \mathrm{~S}\right)$ following the procedure described 
in Craddock et al. (2008). In short, a precise sample solution volume, corresponding to $500 \mu \mathrm{g}$ of $\mathrm{S}$, was evaporated to dryness, dissolved in $1 \mathrm{~mL} 0.28 \mathrm{~mol} / \mathrm{L} \mathrm{HNO}_{3}$ and then purified on a cation exchange chromatographic column AG50-X8 $\left(\mathrm{H}^{+}\right.$form, $2.5 \mathrm{~mL}$ of resin wet volume). The solution that passed through the column contained $\mathrm{S}$ and other oxyanions (e.g., arsenate) whereas other matrix elements were strongly adsorbed on the resin. The final solution was diluted with an appropriate amount of $0.28 \mathrm{~mol} / \mathrm{L} \mathrm{HNO}_{3}$ to obtain a final stock containing $20 \mathrm{ppm} \mathrm{S}$. The use of high resolution sector-field mass spectrometry removes the major isobaric interferences from $\mathrm{O}_{2}{ }^{+}$ (Craddock et al., 2008). Standard-sample bracketing was used to correct for the instrumental mass bias of unknown samples. Background on $\mathrm{S}$ masses was mathematically removed by onpeak zero subtraction and by bracketing of samples with standards determined at the same signal intensity (within 20\%). Based on duplicated $\delta^{34} S$ analysis of internal standard "S-Spex" (Craddock et al., 2008), the precision was estimated at 0.2\%o at 2SD. Results are expressed as $\delta^{34} \mathrm{~S}$ values relative to international notation Vienna-Canyon Diablo Troilite (V-CDT) defined as:

$$
\delta^{34} \mathrm{~S}_{\mathrm{V}-\mathrm{CDT}}=\delta^{34} \mathrm{~S}_{\text {Spex }}-3.0 \%
$$

Because the S-isotope analyses were performed on the same solutions used for elemental concentration determination of the bulk samples (ICP-MS), the measured $\delta^{34} \mathrm{~S}$ may not represent a single-phase S-isotope composition. The seafloor hydrothermal deposits are known to contain sulfates with seawater-derived $\mathrm{SO}_{4}{ }^{2-}$ (e.g., barite and anhydrite) (German and Von Damm, 2006), which may affect the $\delta^{34} \mathrm{~S}$ values of primary hydrothermal sulfides by shifting them towards the heavy $\mathrm{S}$ isotope value of seawater $\left(+20.97 \%\right.$; Paris et al., 2013). Therefore, the $\delta^{34} \mathrm{~S}$ data were considered for possible correction for the effect of trace amounts of sulfate minerals (e.g., $\mathrm{BaSO}_{4}$, $\mathrm{CaSO}_{4}$ ) being dissolved along with the sulfide minerals. The only XRD-detected sulfate in our samples was barite (Table 1). Comparison of the Ba and $\mathrm{S}$ concentrations measured by both ICPMS and XRF showed that the ICP-MS data were systematically lower than the XRF data. This means that the acid digestion for ICP-MS analysis was not efficient in dissolving barite. We calculated the modal abundances of barite in the studied samples using the ICP-MS data and found that barite dissolved in the analyzed solutions varied between 0.004 and 0.01 wt.\%. Assuming $\delta^{34} \mathrm{~S}$ value of $21 \%$ for barite, which is typical for seawater-derived sulfate minerals in the seafloor hydrothermal deposits (Rouxel et al., 2004b), the measured $\delta^{34} \mathrm{~S}$ values of the bulk samples may theoretically be shifted by the calculated barite abundances by up to $0.1 \%$. This is within the analytical uncertainty. Therefore, although the amount of barite in some of our 
samples is significant it does not affect the S-isotope composition of the bulk enargite samples measured by MC-ICP-MS.

\subsubsection{Geochemical modeling}

For discussing the $\mathrm{Cu}$-isotope composition of the studied deposits we modeled $\mathrm{Eh}-\mathrm{pH} \mathrm{Cu}-$ phase diagrams of the inferred mineral-forming fluids using the Geochemist's Workbench 8.0 software based on the "thermo_minteq" database. Physical and chemical parameters of the fluids used in our calculations are discussed in sub-section 5.5.

\section{Results}

\subsection{Mineralogy and textural features}

XRD analysis of bulk samples revealed a similar mineralogical composition: major enargite and luzonite in different proportions, and minor native sulfur, marcasite, covellite, barite, tetrahedrite-tennantite and pyrite (Table 1). The luzonite, which mostly composed the active flange, forms elongated dendritic clusters of fine lamellar crystals (Fig. 3 A) radially oriented towards the lower concave side of the flange (with hot, ponded buoyant fluid). The two layers of the active flange wall have a similar mineralogy (luzonite, enargite), but with different minor phases: the external layer additionally contains covellite, tetrahedrite-tennantite, pyrite and barite. The enargite that builds up the inactive chimney slabs shows large $(3-4 \mathrm{~mm}$ long, $0.5-1 \mathrm{~mm}$ wide), prismatic, euhedral to anhedral crystals (Fig. 3 B). Luzonite exhibits ubiquitous twin lamellae (Fig. 3 B) and aggregates of skeletal crystals, which top the lamellar crystal clusters (Fig. $3 \mathrm{C}, \mathrm{D}$ ). In addition to crystalline luzonite there is also colloform luzonite that is both contemporaneous with and later than the crystalline luzonite, with both mantled by latest colloform marcasite (Fig. 3 E), or later than marcasite and followed by crystalline luzonite (Fig. 3 F). Lamellar covellite forms in the interstities of euhedral luzonite and marcasite (Fig. $3 \mathrm{G}$ ) and in the peripheral parts of the sample where it is overgrown by a second generation of fine-grained luzonite (Fig. $3 \mathrm{H}$ ), possibly an analogue of the colloform luzonite 2.

The large euhedral enargite crystals that compose the inactive chimneys do not show particular morphology or specific features of the crystal faces. The active flange wall is built 
mostly of elongated, smooth bodies of luzonite, built up by dendritic aggregates (Fig. 3 A). The SEM study revealed that these elongated structures (Fig. 4 A, B) are clusters of tiny, radial prismatic crystals (Fig. 4 C, D). The unit-cell parameters for enargite (orthorhombic, hexagonal close-packed structure) and luzonite (tetragonal, cubic close-packed structure) are very close to those reported by Adiwidjaja and Löhn (1970) and Pfitzner and Bernert (2004), respectively, for the pure end members (Table 2).

Optical microscope observations of the external layer (b) of the active flange wall revealed organized filamentous structures composed of luzonite and forming dense, complex networks (Fig. 5). The filaments are $\sim 8-10 \mu \mathrm{m}$ wide and up to $700 \mu \mathrm{m}$ long (Fig. 5 A, B, C). They branch and show septa-like internal features (Fig. 5 D).

\subsection{Mineral chemistry of enargite and luzonite}

Enargite crystals and dendritic luzonite aggregates are not compositionally homogenous: their central zones are slightly enriched in Sb (Fig. 6). As revealed by the EMP analyses across the zoned crystals of enargite and luzonite aggregates, the Sb variations are larger in enargite, whereas Sn and Te are more variable in luzonite (Fig. 7; Appendix 2). A slight deficiency in As and $\mathrm{Sb}$ is characteristic for both, enargite and luzonite, as illustrated by the downward shift of the As-Sb correlation line from the theoretical value (Fig. 7 A). Although the concentrations of Sn and Te are close to the detection limits (Appendix 2), they show well defined correlation trends with $\mathrm{Sb}$ in the two minerals (Fig. $7 \mathrm{~B}, \mathrm{C}$ ). The different slopes of these trends (Fig. $7 \mathrm{~B}, \mathrm{C}$ ) suggest that either different mechanisms for the incorporation of $\mathrm{Sn}$ and Te in the enargiteluzonite crystal lattice (e.g., structural impurities versus presence of sub-micron solid inclusions) or different coefficients of partitioning during mineral precipitation.

LA-ICP-MS analyses of enargite and luzonite revealed large variations in trace element concentrations in both minerals, reaching up to three orders of magnitude in some cases (Fig. 8; Appendix 3). Concentrations of some trace elements such as V, Fe, Ga, Sn, Te, Au and Bi are systematically higher by one to three orders of magnitude in luzonite compared to enargite. Silver is the only element that seems to be preferentially enriched in enargite. Other elements, such as $\mathrm{Mn}, \mathrm{Co}, \mathrm{Ge}, \mathrm{Se}, \mathrm{Mo}, \mathrm{Cd}, \mathrm{In}, \mathrm{Hg}$ and $\mathrm{Pb}$, display similar concentration ranges in enargite and luzonite. 
LA-ICP-MS profiles performed along the central axis of dendritic luzonite aggregates (Fig. 9 A) or core-to-rim profiles across growth banding in enargite, revealed extensive trace element zoning along the direction of crystal growth, indicative of a relative temporal evolution of the chemistry of the ore-forming fluid. Iron, $\mathrm{Ga}, \mathrm{Tl}, \mathrm{Au}, \mathrm{Hg}, \mathrm{Pb}$ and to some extend $\mathrm{Ag}$ show an increase of up to one order of magnitude in their concentration with time during the formation of a single luzonite dendrite (Fig. 9 B, D, E, F). Most of these elements correlate positively with each other (Fig. 9 F). Concentrations of other elements such as Sb, Sn, Te, Ge and V decrease along the direction of crystal growth. Trace metals in a euhedral enargite crystal from sample \#MN 03-11a have similar behavior (Appendix 3). Profiles performed perpendicular to the long axis of the luzonite aggregates or enargite crystals do not show such trends.

The studied (on a crystal level) enargite shows some negligible compositional differences from the enargites from other seafloor hydrothermal fields (Table 3). As we mentioned above (sub-section 4.2, paragraph 1) the investigated enargite-luzonite have only a slight deficiency in As that is compensated by $\mathrm{Sb}, \mathrm{Cu}$ and $\mathrm{S}$. The enargites from other seafloor hydrothermal fields always show smaller deficiencies in $\mathrm{Cu}$ and As (sometimes even in $\mathrm{S}$ ), which are compensated by $\mathrm{Sb}, \mathrm{Fe}, \mathrm{Zn}$ and $\mathrm{Ag}$ (Table 3). Thus, from a mineral chemistry point of view, the studied enargite is more stoichiometric and with less impurities than the enargites from other submarine vent fields. The latter contain more Fe, $\mathrm{Zn}$ and $\mathrm{Ag}$, but less $\mathrm{Hg}$ than the enargite we studied (Table 3).

\subsection{Bulk geochemistry of enargite and luzonite deposits}

Bulk chemical composition of the enargite-luzonite deposits (Table 4) shows some differences, which likely reflects the different bulk mineralogical composition of the samples. In addition to the main mineral-forming elements $[\mathrm{Cu}, \mathrm{As}(\mathrm{Sb}), \mathrm{S}]$ the enargite-luzonite deposits exhibit increased concentrations (usually $>50 \mathrm{ppm}$ on average) of some trace elements: $\mathrm{Pb}, \mathrm{Zn}$, $\mathrm{Bi}, \mathrm{Sn}, \mathrm{Te}, \mathrm{Se}$ and Ag (Table 4). The elements considered as major in silicate petrology (Ca, $\mathrm{Si}$, $\mathrm{Al}, \mathrm{Mg}, \mathrm{K}, \mathrm{Ti}, \mathrm{P}$ and $\mathrm{Mn}$ ) and some trace elements (V, Cd, Cr, Ni, Co, Mo, Tl, In and U) show low contents in these deposits: $<1 \mathrm{wt} . \%$ and $<50 \mathrm{ppm}$, respectively. Particularly high are the concentrations of $\mathrm{Ba}$, that range from 3.63 to 17.7 wt.\% (Table 4). Gold concentrations exceed 1 ppm and reach $27 \mathrm{ppm}$. The wall of the active flange (J2-223-13-R1 a) has the highest $\mathrm{Cu}$ and As 
concentrations, whereas its external layer (J2-223-13-R1 b) contains the highest $\mathrm{S}, \mathrm{Fe}, \mathrm{Ba}$ and $\mathrm{Au}$ (Table 4).

We have compared the metal and metalloid composition of the studied enargite-luzonite deposits to those of hydrothermal sulfide deposits from other BAB and MOR (Table 5). The differences in the contents of major metals and metalloids $(\mathrm{Cu}, \mathrm{Zn}, \mathrm{Pb}, \mathrm{Cd}, \mathrm{As}$ and $\mathrm{Sb}$ ) reflect the fact that the studied deposits are composed of almost pure enargite and/or luzonite (both $\mathrm{Cu}_{3} \mathrm{AsS}_{4}$ ), whereas all the other data average the compositions of a wide range of minerals. Therefore, $\mathrm{Cu}$, As and $\mathrm{Sb}$ concentrations are higher, and $\mathrm{Zn}, \mathrm{Cd}$ and $\mathrm{Pb}$ concentrations are lower in the enargite-luzonite deposits than in all the other reference deposits (Table 5). The trace metal and metalloid composition of the enargite-luzonite deposits we investigated is (in general) similar to that of the sulfide deposits from BAB setting, but shows some differences from that of the MOR sulfide deposits (mafic- and ultramafic-hosted) (Table 5). Enargite-luzonite deposits are enriched in $\mathrm{Au}, \mathrm{Ag}, \mathrm{Bi}$ and $\mathrm{Te}$, depleted in Se, Co, Ni, Mn, Mo and $\mathrm{U}$, and have similar concentrations of In and Tl to those of the MOR sulfides (Table 5). Their Sn contents are higher than those of the other BAB deposits, but they are comparable to those of the MOR sulfides (Table 5).

Using the XRF data and considering the minerals identified by XRD, we calculated the modal abundances of mineral assemblages in the bulk samples. Calculations showed that enargite-luzonite represented 16-91 wt.\%, barite 7-31 wt.\% and marcasite/pyrite 2-25 wt.\% of the samples.

\section{4. $S$ and $C u$ isotope composition}

The $\delta^{34} \mathrm{~S}$ values of all the studied samples are negative and range from -3.70 to $-8.58 \%$ (Table 4; Fig. 10), whereas the only study of S-isotopes in seafloor hydrothermal enargite we are aware of (Pracejus, 2000) reports positive $\delta^{34} \mathrm{~S}_{\mathrm{V}-\mathrm{CDT}}$ values $(+7.05-+9.91 \%$ ) for stockwork enargite from the JADE hydrothermal field (Okinawa Trough).

$\mathrm{Cu}$-isotope composition across the active flange wall (J2-223-13-R1; Table 6, Fig. 11) showed relatively narrow variations of $\delta^{65} \mathrm{Cu}$ from -0.20 to $0.13 \%$ with $\delta^{65} \mathrm{Cu}_{\text {average }}=-0.08 \%$. The most frequent $\delta^{65} \mathrm{Cu}$ values cluster around $-0.10 \%$ (Fig. 11). The average $\delta^{65} \mathrm{Cu}$ is close to the reported average value for primary enargite $\left(\delta^{65} \mathrm{Cu}=-0.01 \%\right.$; Kimball et al., 2009) from 
epithermal high-sulfidation hydrothermal systems (Bove et al., 2007). The $\delta^{65} \mathrm{Cu}$ data obtained on bulk sub-samples are in good agreement (within $2 \sigma$ ) with the detailed point analyses (Fig. 11): the internal layer of the active flange (J2-223-13-R1 a) has $\delta^{65} \mathrm{Cu}=-0.19 \%$ (against $-0.10 \%$ ) whereas its external layer (J2-223-13-R1 b) shows $\delta^{65} \mathrm{Cu}=0.10 \%$ (against $0.07 \%$ ) (Table 6, Fig. 11). The other two enargite-luzonite samples (bulk) show positive $\delta^{65} \mathrm{Cu}$ values defining an enargite-luzonite $\delta^{65} \mathrm{Cu}$ range from -0.20 to $0.35 \%$ (Tables 4,6 ).

In comparison, previous studies of the $\mathrm{Cu}$-isotope composition of chalcopyrite from the Logatchev seafloor hydrothermal field reported highly variable values, ranging from -0.98 to $+3.62 \%$ (Rouxel et al., 2004a). The range of $\delta^{65} \mathrm{Cu}$ values for chalcopyrite in hydrothermal chimneys and massive sulfides from the Lucky Strike vent field vary from -0.5 to $+0.8 \%$, with variation within individual chimneys being less than $0.4 \%$. Hence, the range of $\delta^{65} \mathrm{Cu}$ of the enargite-luzonite assemblage is relatively limited, and is close to the oceanic basalt crust value $\sim 0.0 \%$ (Dekov et al., 2013b).

Across the wall of the active enargite-luzonite flange (J2-223-13-R1), $\delta^{34} \mathrm{~S}$ increases from the internal to the external layer (from $-4.84 \%$ to $-3.70 \%$, respectively). A similar trend is observed in the distribution of the $\delta^{65} \mathrm{Cu}$ values (Fig. 11).

\section{Discussion}

\subsection{Conditions of enargite-luzonite inorganic precipitation}

Enargite is generally considered to be a high-temperature polymorph, inverting to luzonite at temperatures below $\sim 300^{\circ} \mathrm{C}$ (Maske and Skinner, 1971). However, a study by Bernardini et al. (1973) showed that these two polymorphs coexist metastably at temperatures between $215 \pm 15^{\circ}$ and $315 \pm 15^{\circ} \mathrm{C}$. This suggests that an enargite-luzonite mineral paragenesis could precipitate at $\mathrm{T}=200^{\circ}-330^{\circ} \mathrm{C}$.

The fluids venting from the studied active flange have $\mathrm{T}=212^{\circ} \mathrm{C}$. The measured temperatures of vent fluids at the other North Su sites generally range between $215^{\circ}$ and $325^{\circ} \mathrm{C}$ (five vents) with only one vent emitting fluids with $\mathrm{T}=48^{\circ} \mathrm{C}$ (Tivey et al., 2007). This suggests that the studied enargite-luzonite deposits may have precipitated at $\mathrm{T}=200^{\circ}-330^{\circ} \mathrm{C}$. 
The enargite is the most common high-sulfidation [reflecting a high $\mathrm{S}$-fugacity $\left.\left(\mathrm{fS}_{2}\right)\right] \mathrm{Cu}-$ mineral that is known from the high- to very high- sulfidation enargite-covellite ores (Einaudi et al., 2003). In general, the bulk of the massive sulfides form under conditions of intermediate- to low-sulfidation states and therefore, high- to very high-sulfidation state sulfide mineral assemblages are uncommon in ancient volcanic-hosted massive sulfide deposits (Sillitoe et al., 1996; Hannington et al., 1999; Scotney et al., 2005). With respect to modern seafloor sulfide deposits, only a few of them have been documented to contain high- to very high-sulfidation state sulfide minerals (Hannington et al., 1999). Enargite co-existing with tennantite and/or covellite has been found in back-arc [Bransfield Strait (Petersen et al., 2004), Okinawa Trough (Lüders et al., 2001; Watanabe et al., 2006; Suzuki et al., 2008)] and arc [southern Mariana Trough (Iwaida and Ueno, 2005), Aegean Arc (Alfieris et al., 2013), Aeolian Arc (Petersen et al., 2014)] settings. However, at all these sites, enargite (+ covellite) represents only a volumetrically minor phase of the sulfide deposits and its presence suggests that enargite (+ covellite) formed during transient high-sulfidation periods at these sites. Only two occurrences of luzonite have been reported at seafloor hydrothermal sites so far [both in arc setting: Aegean Arc (Alfieris et al., 2013) and Aeolian Arc (Petersen et al., 2014)].

Why enargite and luzonite have dominantly been observed in back-arc and arc settings and form massive deposits at the summits of the studied volcanoes, also requires consideration of the concentration of another essential component in these minerals, arsenic, in the deposit-forming fluids. We have not sampled and investigated the fluids precipitating the studied samples and are not able to present the As concentrations in them. However, a study by Douville et al. (1999) reported the As concentrations and speciation in a set of seafloor vent fluids from different settings. The presented results show that the As contents in hydrothermal fluids from the Manus BAB (PACMANUS and Desmos vent fields) are 10- to 100-fold higher than the As concentrations in the vent fluids from MOR setting (East Pacific Rise and Mid-Atlantic Ridge). This particular As enrichment in the BAB hydrothermal fluids is explained by the interaction of seawater with felsic rocks (Douville et al., 1999), which are enriched in As compared to the MOR basalts (Noll et al., 1996). In addition, the As concentrations in the BAB hydrothermal fluids are likely controlled by phase separation processes and the volatile $\mathrm{H}_{3} \mathrm{AsO}_{3}{ }^{0}$ (aq) is the dominant As species (Douville et al., 1999). 
Along with the enargite-luzonite deposits, the North $\mathrm{Su}$ and Kaia Natai hydrothermal fields contain a number of chalcopyrite-pyrite chimneys (Auzende et al., 2000; Moss and Scott, 2001; Craddock, 2009). It is challenging to understand why the same hydrothermal system precipitates massive enargite-luzonite deposits at one site and chalcopyrite-pyrite at another.

In general, mineral precipitation at seafloor hydrothermal vents is controlled by both the fluid composition and the conditions of precipitation. Differences in the mineral composition and morphology (different types of chimneys, flanges, ledges, mounds) of the hydrothermal vents are largely controlled by the styles of fluid flow (focused, diffused, rapid, slow, etc.) and conditions of mineral precipitation within the chimney wall rather than by the differences in the end-member hydrothermal fluid composition (Tivey, 1995). In particular, flanges and diffuser chimneys are characterized by low vertical advection rates through a porous wall/flange, which likely leads to some conductive cooling of the hydrothermal fluid (Fouquet et al., 1993b; Koski et al., 1994). In turns, this leads to the precipitation of sulfides over a larger range of temperature, $\mathrm{pH}$ and hydrothermal fluid composition (e.g., metal and $\mathrm{H}_{2} \mathrm{~S}$ concentrations, $\mathrm{fO}_{2}$ and $\mathrm{fS}_{2}$ ) inside the chimney structure (Tivey, 1995). Hence, the occurrence of enargite-luzonite chimneys in the same hydrothermal field along with chalcopyrite black smokers may be controlled by the style of venting.

Thus, the studied enargite-luzonite deposits likely precipitated at fluid temperatures between $200^{\circ}$ and $330^{\circ} \mathrm{C}$, at consistent long-term high-sulfidation conditions, and high As concentrations.

\subsection{Biogenic precipitation of luzonite in the active hydrothermal flange}

Modern seafloor hydrothermal systems host diverse microbial communities (Rogers et al., 2003; Nercessian et al., 2005; Kormas et al., 2006; Blumenberg et al., 2007; Huber et al., 2007; Perner et al., 2007) that are recognized to play an important role in mineral precipitation and rock alteration at the seafloor (Edwards et al., 2004; Glynn et al., 2006; Toner et al., 2009). Filamentous micro-organisms are inferred to inhabit ancient seafloor hydrothermal fields and mediate precipitation of sulfides and oxyhydroxides (Rasmussen, 2000; Little et al., 2004). However, since mineralized filamentous micrometer-sized structures may be produced abiotically 
(Hopkinson et al., 1998; García-Ruiz et al., 2003) the inference that such structures are biogenic is not always unambiguous.

Observations of the external layer (b) of the active flange suggest that the complex mycelium-like network of luzonite (Fig. 5) with single-filament size larger than that of bacteria and similar to that of fungal hyphae (Fig. 5 C), branching (Fig. 5 A, B), morphology of the filament tips corresponding to the smooth fungal hyphal tips (Fig. 5 A, B, C) and putative septa (Fig. 5 D) may be of fungal origin. Visualization of the putative septa suggests that these mineralized fungal-like filaments may be affiliated to the Dikarya subkingdom including the Ascomycota and Basidiomycota phyla, the so-called higher fungi. However, without visualization of spore-like structures and conidiogenesis, it is impossible to obtain more information regarding their taxonomy.

Previous observations of fungal inhabitation, activity and functions in the seafloor hydrothermal ecosystems and in the deep sub-seafloor (Burgaud et al., 2009, 2010; Edgcomb et al., 2011; Ivarsson et al., 2012; Orsi et al., 2013; Ciobanu et al., 2014) strongly support the idea that fungi thrive in the seafloor hydrothermal systems. Recently, it was hypothesized that the fungal organic matter in the seafloor hydrothermal systems can serve as a geochemical trap for hydrothermally released As, which may react with $\mathrm{S}$ and mineralize the fungal hyphae as orpiment, $\mathrm{As}_{2} \mathrm{~S}_{3}$ (Dekov et al., 2013a). Biological observations showed that the external layers of hydrothermally active flanges were intensely populated by different communities (bacteria, worms, etc.) (Woods and Delaney, 1992; Sarrazin et al., 1997; Tokeshi, 2011; Callac et al., 2015). Our results indicate that fungi living at the seafloor hydrothermal sites (e.g., at the flanges of active chimneys) may not only be implicated in a mechanism of bio-sequestration of As and $\mathrm{S}$ (orpiment), but also in the biogenic precipitation of $\mathrm{As}, \mathrm{S}$ and $\mathrm{Cu}$ (luzonite). While recent studies have unambiguously revealed active fungal communities in the seafloor hydrothermal systems with many Dikarya representatives, our study suggests that a possible fate of the fungi in these ecosystems could be a dead-end bio-sequestration of $\mathrm{As}, \mathrm{S}$ and $\mathrm{Cu}$. Thus, the fungi presence at the seafloor hydrothermal sites seems to be related to the mechanisms of mineral precipitation and eventually, to the mineralogy of hydrothermal deposits.

\subsection{Enargite-luzonite as prime carriers for trace elements}


Previous studies (EMP, LA-ICP-MS) of enargite-rich high-sulfidation epithermal deposits on land indicated significant variability in the trace element composition of enargite at individual crystal to ore body scales (Sutopo et al., 2007; Deyell and Hedenquist, 2011; Maydagán et al., 2013; King et al., 2014) with very few consistent elemental correlations in the enargite (Deyell and Hedenquist, 2011). Despite this trace element compositional variability, and its seemingly intricate explanation, there are two characteristics that appear in all the enargite deposits on land: (1) the main "trace" element in enargite is $\mathrm{Sb}$; (2) the most abundant trace elements in enargite are those that can form discrete sulfosalts, selenides and tellurides: $\mathrm{Bi}, \mathrm{Sn}, \mathrm{Se}, \mathrm{Te}, \mathrm{Ag}$ and $\mathrm{Zn}$ (Deyell and Hedenquist, 2011).

Antimony substitution for As in enargite-luzonite is well documented (Pósfai and Buseck, 1998) and the enhanced Sb concentrations (up to $5.34 \mathrm{wt} . \%$ ) in both studied enargite-luzonite and enargite from other seafloor hydrothermal fields (Table 3) is not surprising. The observed compositional zoning in the enargite and luzonite (Fig. 6), as well as the trace element variations in them (Fig. 9) may be indicative of small scale fluctuations in the trace element content of the hydrothermal fluid during enargite/luzonite deposition (cf., Pósfai and Buseck, 1998).

Most of the trace elements that exhibit enhanced concentrations in the enargite deposits on land (e.g., Bi, Sn, Se, Te, Ag and Zn; Deyell and Hedenquist, 2011; Maydagán et al., 2013; King et al., 2014) also show high abundances (commonly within an order of magnitude) in the studied enargite-luzonite (Table 5; Appendixes 2, 3). Figure 12 summarizes trace element concentrations in enargite from the Manus Back-Arc Basin, compared to published data on enargite from highsulfidation mineralization from magmatic-hydrothermal systems: Lepanto (Philippines), Altar (Argentina) and Sangihe (Indonesia). The similarity in the geochemical patterns of trace elements in enargite implies that both types of deposits may have similar source and/or mobilizationprecipitation mechanisms of trace elements.

The ancient hydrothermal systems that deposited the enargite ore bodies mined recently on land are not active anymore and it is impossible to find any direct relations between the oreforming fluid chemistry and the trace element composition of the ores. However, the active hydrothermal systems on modern seafloor provide this opportunity. Trace metal concentrations in the seafloor hydrothermal fluids have been shown to be controlled by the combined effects of source rock composition, brine-seawater mixing and complex interplay among various metals and minerals deposited and remineralized in hydrothermal deposits (Metz and Trefry, 2000; 
Douville et al., 2002). Thus, the relative enrichments of these trace metals in the vent fluids vary significantly between MOR hydrothermal systems, those located in BAB, and those covered by a significant sediment blanket (German and Von Damm, 2006). Although the correlation between the trace-metal composition of the seafloor vent fluids and hydrothermal deposits is not always straightforward, ample evidence suggests that the source rock composition (Douville et al., 2002) and conditions of venting (Metz and Trefry, 2000) exert a significant control on the trace-metal composition of the final deposits.

Previous studies showed that the enrichment of $\mathrm{Co}, \mathrm{Ni}$, and $\mathrm{Se}$ in the hydrothermal vents is related to the abundances of chalcopyrite, whereas the increased concentrations of $\mathrm{Cd}, \mathrm{Pb}, \mathrm{As}$, $\mathrm{Sb}, \mathrm{Ag}, \mathrm{Ge}$, and $\mathrm{Sn}$ in the same type of deposits correlate to the abundances of sphalerite and accessory minerals (galena, sulfosalts) (Fouquet et al., 2010). Thus, the crystallography (mineralogy) is likely an additional control on the trace element composition of seafloor hydrothermal deposits.

Although interpretation of the trace-metal controls in the seafloor enargite-luzonite deposits is not a particular focus of this study, we hypothesize that the host rock composition and mineralogy of the deposits account for the differences in trace element chemistry of the enargiteluzonite deposits and MOR sulfides, and the similarities of trace element composition of the enargite-luzonite deposits with BAB sulfides (Table 5; Appendixes 2, 3).

Two trace elements show the highest average concentrations in the enargite-luzonite deposits compared to all the other seafloor hydrothermal sulfide deposits: Au (average 11.9 ppm, range $1.9-27 \mathrm{ppm}$ ) and Te (average $169 \mathrm{ppm}$, range $0.8-602 \mathrm{ppm}$ ) (Table 5). We realize that this conclusion may result from both our limited data set that considers almost pure enargiteluzonite deposits (in comparison to the other data reported in Table 5 that average the composition of a number of different minerals) and the limited data on Te content in the literature. Even though these data point out that $\mathrm{Au}$ and $\mathrm{Te}$ are particularly enriched in the enargite-luzonite deposits and may potentially present an economic interest in the future (Hoagland et al., 2010).

It has been suggested that $\mathrm{Au}$ is either structurally bound within the enargite-luzonite crystal lattice, or it occurs as sub-micron native Au inclusions (Deyell and Hedenquist, 2011). We did not observe any $\mathrm{Au}^{0}$ nuggets during the optical microscope investigations of our samples 
even at the highest magnification $(5000 \times)$, indicating that the $\mathrm{Au}$ is present as sub-microscopic inclusions or as a chemical constituent within the investigated minerals.

Previous studies demonstrated that the enrichment of $\mathrm{Au}$ in the seafloor hydrothermal deposits is consistently related to the late-stage minerals precipitated at temperatures $<300^{\circ} \mathrm{C}$ (Hannington et al., 1991). They also suggested that the sulfosalts are effective repositories for $\mathrm{Au}$. Considering that $\mathrm{Au}$ in the studied deposits is particularly enriched in the samples containing not only enargite and luzonite, but also covellite, pyrite and marcasite (Tables 1, 4), we may conclude that $\mathrm{Au}$ is likely associated with a complex sulfosalt-sulfide mineral paragenesis.

Tellurium has been estimated to be extremely enriched (more than any other element relative to its Earth's crustal mean) in one type of seafloor deposit: hydrogenetic Fe-Mnoxyhydroxide crusts (Hein et al., 2003). In these crusts, Te concentration varies from 3 to 205 ppm with mean contents for Pacific and Atlantic crusts of $\sim 50 \mathrm{ppm}$ and a mean of $39 \mathrm{ppm}$ for Indian crusts (Hein et al., 2003). Therefore, the oceanic Fe-Mn-oxyhydroxide crusts are considered as a potential Te resource. Tellurium concentrations (average and range) of the studied enargite-luzonite deposits exceed those of the Fe-Mn-oxyhydroxide crusts by an order of magnitude and place them among the potential future Te resources.

In-situ LA-ICP-MS analyses of the trace elements in enargite and luzonite from the studied samples revealed contrasting concentration ranges of some elements in the two minerals (Fig. 8). Morphological differences between the two phases are indicative of different crystal growth regimes: euhedral enargite crystals were formed by slow crystal growth (i.e., under nearequilibrium conditions), while luzonite skeletal aggregates testify of rapid crystal growth from supersaturated fluid. This could potentially explain the difference in trace element signatures of the two phases, because rapid crystal growth could be responsible for incorporation of submicron solid inclusions that could be partially responsible for the difference in trace element concentrations between the two phases.

\subsection{Importance of magmatic volatiles in producing $C u$-sulphosalt seafloor mineralization: $S$ -} isotope constraints

The S-isotope systematics of the seafloor hydrothermal systems has been discussed in a number of works (e.g., Shanks, 2001; Ono et al., 2007). Sulfides from mafic-hosted 
unsedimented ridges show (in general) positive $\delta^{34} \mathrm{~S}$ values $(\sim 0-10 \%$ ) between those of the mantle sulfide $(-0.91 \pm 0.50 \%$ ) and seawater sulfate (20.97\%) (Fig. 10). The sulfides from ultramafic-hosted unsedimented ridges have similar S-isotope composition. Sulfides from sedimented ridges exhibit a slightly wider range of $\delta^{34} S$ going to negative values (Fig. 10), which are explained by hydrothermal remobilization of biogenic $S$ with isotopic compositions lighter than that of the mantle sulfide (Shanks, 2001). Hydrothermal sulfides from volcanic arc and BAB settings show wide $\mathrm{S}$-isotope variability: $\delta^{34} \mathrm{~S}=-39.3$ to $+8.3 \%$ (Fig. 10). Sulfides from some BAB hydrothermal fields yield negative $\delta^{34} \mathrm{~S}$ values [down to $-9 \%$ with respect to V-CDT; Herzig et al. (1998), Kim et al. (2004), de Ronde et al. (2005), Gena et al. (2006)] attributed to disproportionation of magmatic $\mathrm{SO}_{2}$ that originally had $\delta^{34} \mathrm{~S}_{\mathrm{SO} 2} \sim 0-3 \%$. In this respect, the negative $\delta^{34} \mathrm{~S}$ values of the studied enargite-luzonite samples (Table 4) deserve particular attention.

A previous $\mathrm{S}$-isotope study of a $\mathrm{Cu}$-rich sulfide chimney from the location area of two of our enargite samples (SuSu Knolls) revealed negative $\delta^{34} \mathrm{~S}$ values (-8.0 to $-3.9 \%$; Kim et al., 2004) that fall within the $\delta^{34} \mathrm{~S}$ range of our enargite-luzonite deposits: $-8.58--3.70 \%$ (Fig. 10). In principle, the negative $\delta^{34} \mathrm{~S}$ values might be ascribed to: (1) subsurface remobilization of isotopically light $\mathrm{S}$ produced through microbial sulfate reduction; (2) hydrothermal fluid boiling; and (3) magmatic degassing (Herzig et al., 1998a; Shanks, 2001; Kim et al., 2004). Submersible and ROV observations at our sampling sites did not reveal any sediment cover and we do not see any reason to assume substantial biogenic light $S$ source to the enargite-luzonite vents. $\delta^{34} S$ variations in vent fluids due to boiling and phase separation are considered indiscernible (Shanks, 2001) and we may rule out the vent fluid boiling processes (wide spread in the East Manus Basin vent fields; Reeves et al., 2011) as an effective mechanism to generate ${ }^{32} \mathrm{~S}$ enrichment in the fluids. Although we do not have data on the chemistry and S-isotope composition of the fluids venting from the enargite-luzonite vents there is ample evidence for magmatic volatile contribution to the hydrothermal systems of the North Su (Seewald et al., 2006; Tivey et al., 2007; Craddock, 2009) and the closely situated Desmos and PACMANUS fields (Gamo et al., 1997; Reeves et al., 2011). Therefore, we assume that disproportionation of magmatic $\mathrm{SO}_{2}$ [invoked to explain the negative $\delta^{34} \mathrm{~S}$ values of vent fluid $\mathrm{H}_{2} \mathrm{~S}$ and sulfides at other fields (Herzig et al., 1998a; Shanks, 2001; Kim et al., 2004)] is the most plausible mechanism explaining the negative $\delta^{34} \mathrm{~S}$ values of studied enargite-luzonite. 
Hence, the consistent long-term high $\mathrm{fS}_{2}$ required for precipitation of massive enargiteluzonite deposits (see 5.1) is likely provided by direct magmatic input of $\mathrm{SO}_{2}$ into the hydrothermal system. $\mathrm{SO}_{2}$ disproportionates into isotopically light sulfide $\left(\mathrm{H}_{2} \mathrm{~S}\right)$ and heavy sulfate $\left(\mathrm{H}_{2} \mathrm{SO}_{4}\right)$. Further, the sulfide reacts with dissolved $\mathrm{Cu}^{+}$species and $\mathrm{Cu}$-sulphosalts with negative $\delta^{34} \mathrm{~S}$ values precipitates.

\subsection{Cu-isotope fractionation during enargite-luzonite precipitation in a flange wall}

In order to understand the $\mathrm{Cu}$-isotope fractionation during the formation of the flange we need to consider: (1) the mode of flange formation; and (2) the $\mathrm{Cu}$ speciation in the parent vent fluid and its evolution across the flange wall.

Woods and Delaney (1992) have investigated and modeled the heat and fluid flux through an active flange. They found that the hydrothermal fluid ponded below the flange is isothermal and buoyant. Therefore, it is driven upwards through the overlaying porous flange (Fig. 2 B). The thermal gradients in the interior of the flange (layer a in our sample) are small and the fluid is stable to Rayleigh-Darcy instabilities except in the narrow external layer at the top of the flange (layer b in our sample) (Woods and Delaney, 1992). Direct measurements of the temperature at the upper surface of the flanges showed a temperature range of $10-80^{\circ} \mathrm{C}$ (Woods and Delaney, 1992). Woods and Delaney (1992) concluded that the major part of the flange remains as a relatively unconsolidated, nearly isothermal matrix of sulfides saturated with hydrothermal fluid and only in the external layer does the mineralogy changes as low-temperature minerals precipitate.

Following this model we consider that the temperature in the layer a of the studied flange was $212^{\circ} \mathrm{C}$ whereas in layer $\mathbf{b}$ it is assumed to be $\sim 50^{\circ} \mathrm{C}$ [mean of the temperature range measured by Woods and Delaney (1992)]. We used these two temperatures and $\mathrm{p}=122$ bars [hydrostatic pressure at the water depth of the flange, $1225 \mathrm{~m}$ (Table 1)] in the modelling of pHEh diagrams of $\mathrm{Cu}$ stability in the fluid passing through the porous flange (Fig. 13). Because we do not have chemistry data ( $\mathrm{pH}$, ion concentrations) for the hydrothermal fluid venting from the enargite-luzonite flange we have used those for the closest active vent J2-223-15-W1-M4 (Craddock, 2009) in our modelling: $[\mathrm{Cl}]=663 \mathrm{mmol} / \mathrm{kg},\left[\mathrm{SO}_{4}\right]=2.5 \mathrm{mmol} / \mathrm{kg},[\mathrm{F}]=326$ $\mu \mathrm{mol} / \mathrm{kg},[\mathrm{Fe}]=5331 \mu \mathrm{mol} / \mathrm{L}$, and $[\mathrm{Cu}]=73 \mu \mathrm{mol} / \mathrm{L}$. 
Calculated Eh-pH diagrams under the above conditions (Fig. 13) show that $\mathrm{Cu}^{+}$species are dominant in the fluid at $\mathrm{T}=212^{\circ} \mathrm{C}$ (in layer a) and within the $\mathrm{pH}$ range measured in the North $\mathrm{Su}$ active vents (0.9 - 4.8; Craddock, 2009) (Fig. 13 A). The stability field of $\mathrm{Cu}^{+}$shrinks slightly when the fluid temperature decreases to $\mathrm{T}=50^{\circ} \mathrm{C}$ (in layer $\mathbf{b}$ ) and within the above mentioned $\mathrm{pH}$ range (Fig. $13 \mathrm{~B}$ ). The mineralogy of the flange (see 4.1) suggests that $\mathrm{Cu}$ in the solids of the internal layer $\mathbf{a}$ is as $\mathrm{Cu}^{+}$(luzonite, enargite; Di Benedetto et al., 2011), whereas in the external layer $\mathbf{b}$ a little proportion of solid $\mathrm{Cu}$ is in the form of $\mathrm{Cu}^{2+}$ phases (tetrahedrite-tennantite; Pattrick et al., 1993; Di Benedetto et al., 2002), but generally it will be as $\mathrm{Cu}^{+}$(luzonite, enargite, covellite). In other words, in the internal flange layer (a) $\mathrm{Cu}$ is dominantly present as $\mathrm{Cu}^{+}$in the percolating fluid and only as $\mathrm{Cu}^{+}$in the solids, whereas in the external layer (b) a small proportion of the $\mathrm{Cu}$ may be as $\mathrm{Cu}^{2+}$ in both the fluid and solids although its major part is still as $\mathrm{Cu}^{+}$.

The active flange forms during the interaction of two contrasting fluids, hydrothermal fluid and deep seawater (Fig. 2 B). Considering that the $\mathrm{Cu}$ concentration of deep seawater (0.003 $\mu \mathrm{mol} / \mathrm{L}$, north Tasman Sea; Thompson et al., 2013) is four orders of magnitude lower than that of the vent fluid (72 $\mu \mathrm{mol} / \mathrm{L}$, mean of North Su vent fluids; Craddock, 2009), simple mass-balance calculations suggest that $\mathrm{Cu}$ in the forming flange derives essentially from the hydrothermal fluid even if we assume $99 \%$ seawater proportion in the mixed fluid. Hence, the vent fluid is the major $\mathrm{Cu}$ source to the flange and $\mathrm{Cu}$-isotope fractionation across it is not influenced by the $\mathrm{Cu}$ isotope composition of seawater.

If we assume that the mean $\delta^{65} \mathrm{Cu}(0.45 \%)$ and its range $(0.00-1.16 \%$ ) in the analyzed six North Su vent fluids (Rouxel et al., 2016) is representative of the venting flange fluid then we may infer that the $\mathrm{Cu}$ source to the growing flange had isotopically heavy $\mathrm{Cu}$ isotope composition relative to the precipitated $\mathrm{Cu}$ minerals. Then, the precipitation of $\mathrm{Cu}$ minerals across the flange seems to have resulted in $\mathrm{Cu}$-isotope fractionation with negative $\delta^{65} \mathrm{Cu}$ values (mean $-0.19 \%$ ) in the internal layer (a) and positive $\delta^{65} \mathrm{Cu}$ values (mean $0.10 \%$ ) in the external layer (b) (Fig. 11).

As we concluded above, the precipitation of luzonite-enargite is not accompanied by changes in the oxidation state of $\mathrm{Cu}$ in the internal flange layer $\mathbf{a}\left(\mathrm{Cu}^{+}\right)$and only negligible $\mathrm{Cu}$ oxidation $\left(\mathrm{Cu}^{2+}\right)$ may occur in the external layer $\mathbf{b}$. Although theoretical calculations predict that Cu-isotope fractionation should also accompany non-redox reactions (Seo et al., 2007; Fujii et 
al., 2013, 2014), the $\mathrm{Cu}$-isotope fractionation factors between dissolved $\mathrm{Cu}^{+}$species and $\mathrm{Cu}^{+}-$ sulfides (e.g., enargite, covellite) remain unknown. If the negative $\delta^{65} \mathrm{Cu}$ values we observe in the internal layer (a) represent a fractionation factor between the vent fluid and luzonite-enargite, then the $\delta^{65} \mathrm{Cu}$ values of the external layer (b) should be even more negative due to the expected larger fractionation factor at lower temperature. This is the opposite of what we observe and suggests another mechanism of fractionation.

Below we discuss two possible mechanisms of fractionation that may have been responsible for the $\mathrm{Cu}$-isotope compositions we observe across the flange wall:

(I) It is well accepted that the largest $\mathrm{Cu}$-isotope fractionations are associated with redox processes (up to $\Delta^{65} \mathrm{Cu}_{\mathrm{Cu}(\mathrm{II})-\mathrm{CuS}} \approx 3.5 \%$; Rouxel et al., 2004a; Mathur et al., 2005; Markl et al., 2006; Asael et al., 2007, 2009; Haest et al., 2009; Mathur et al., 2009). Asael et al. (2009) have proposed that the $\mathrm{Cu}$-isotope composition of $\mathrm{Cu}^{+}$and $\mathrm{Cu}^{2+}$ species in solution is controlled by their mass balance in the solution and the redox fractionation factor $\left(\Delta^{65} \mathrm{Cu}_{\mathrm{Cu}(\mathrm{II})-\mathrm{Cu}(\mathrm{I})}\right)$. If the conditions are well within the field of $\mathrm{Cu}^{+}$species (in our case $\mathrm{CuCl}_{3}{ }^{2-}$; Fig. 13) the amount of $\mathrm{Cu}$ found in $\mathrm{Cu}^{2+}$ species (in our case $\mathrm{CuOH}^{+}$or $\mathrm{CuCl}^{+}$) will be negligible, and the $\delta^{65} \mathrm{Cu}$ value of the $\mathrm{Cu}^{+}$species and therefore of the precipitated $\mathrm{Cu}^{+}$-minerals will directly reflect that of the bulk solution. However, if the conditions are closer to the equilibrium lines between the $\mathrm{Cu}^{+}$and $\mathrm{Cu}^{2+}$ species (Fig. 13), the $\mathrm{Cu}^{2+}$ species become more abundant in the solution, and the $\delta^{65} \mathrm{Cu}$ value of the dissolved $\mathrm{Cu}^{+}$species and therefore of the precipitated $\mathrm{Cu}^{+}$-minerals will become negative with respect to the bulk solution. The more the $\mathrm{Cu}^{2+}$ species become dominant (closer to the equilibrium lines; Fig. 13), the more negative the $\delta^{65} \mathrm{Cu}$ value of the $\mathrm{Cu}^{+}$phases will be. It is therefore possible that the negative $\delta^{65} \mathrm{Cu}$ values we observe in the internal layer (a) reflect direct precipitation from a negative $\mathrm{Cu}^{+}$pool in the solution.

The positive $\delta^{65} \mathrm{Cu}$ values of the external layer (b) (Fig. 11) are a result of positive fractionation associated with $\mathrm{Cu}^{+}$oxidation to $\mathrm{Cu}^{2+}$ due to vent fluid/seawater mixing and precipitation of $\mathrm{Cu}^{2+}$ phases.

(II) As mentioned above, the hydrothermal fluid is trapped below the flange and flows upward through its porous wall. This leads to mineral precipitation and it is possible that $\mathrm{Cu}-$ isotope composition of the percolating fluid may follow Rayleigh-type fractionation pathway. In this case, the precipitation of isotopically light $\mathrm{Cu}^{+}$-sulfide (e.g., Zhu et al., 2002; Ehrlich et al., 2004; Anbar and Rouxel, 2007) in the flange internal layer (a) would leave the residual fluid 
enriched in heavy $\mathrm{Cu}$-isotope $\left({ }^{65} \mathrm{Cu}\right)$, leading to the precipitation of isotopically heavier $\mathrm{Cu}$ minerals (enargite-luzonite, covellite) in the external layer (b). This model seems to be consistent with the observed $\mathrm{Cu}$ isotope values across the flange wall (Fig. 11).

\subsection{Significance of seafloor enargite-luzonite deposits}

Volcanic-hosted massive enargite ores have been exploited for their $\mathrm{Cu}, \mathrm{Au}$ and $\mathrm{Ag}$ contents at many deposits on land (Sillitoe, 1983; Simmons et al., 2005; Laznicka, 2010; Sillitoe, 2010). This deposit subclass (high-sulfidation epithermal; Heald et al., 1987; Hedenquist et al., 2001) forms at convergent plate margins in BAB and volcanic arc settings (Simmons et al., 2005; Sillitoe, 2010; Richards, 2011), and is always associated with acid-sulfate hydrothermal alteration (Ashley, 1982; Sillitoe, 1983). Altered (advanced argillic stage) intermediate volcanic rocks usually host these deposits. Sulphosalts (enargite-luzonite and tennantite-tetrahedrite) dominate the deposit mineralogy. Pyrite is another ubiquitous phase. Barite and native $S$ are among the important gangue minerals (Ashley, 1982; Sillitoe, 1983). These deposits usually have Au/Ag > $1 / 3$, but might also be Ag-rich. Boiling of the ore-precipitating hydrothermal fluids is inferred to commonly occur during the mineralization. Temperatures of ore formation are estimated to be from $<200^{\circ} \mathrm{C}$ to $>300^{\circ} \mathrm{C}$ (Ashley, 1982; Mancano and Campbell, 1995; Kouzmanov et al., 2004; Moritz and Benkhelfa, 2009). Stable isotope data indicate a substantial contribution of magmatic fluids (Simmons et al., 2005).

The studied enargite-luzonite deposits have characteristics similar to those of the highsulfidation epithermal deposits: BAB setting, venting both acid-sulfate and boiling fluids in the same hydrothermal field (Craddock et al., 2010; Reeves et al., 2011), $\mathrm{T}_{\text {vent fluids }}=48-325^{\circ} \mathrm{C}$, altered (advanced argillic stage; Yeats et al., 2000) dacitic host rocks, major enargite-luzonite and minor pyrite, barite and $S^{0}$. Additionally, their $S$-isotope composition $\left(\delta^{34} S<0 \%\right)$ is similar not only to that of the seafloor sulfides from arc/back-arc setting, but also to the S-isotope composition of enargites from high-sulfidation epithermal deposits on land (Fig. 10). Therefore, these deposits may be considered as submarine equivalents to subaerial high-sulfidation epithermal mineralization (Laznicka, 2010).

Enargite-bearing high-sulfidation epithermal deposits on land are commonly found to occur spatially and genetically associated with porphyry $\mathrm{Cu}$ deposits (Ashley, 1982; Sillitoe, 1983; 
Hedenquist and Lowenstern, 1994; Arribas, 1995; Hedenquist et al., 1998; Sillitoe, 2010). In some cases, the enargite-bearing replacement ore bodies and veins are developed above or peripheral to the porphyry stocks (e.g., Lepanto-FSE, Philippines: Hedenquist et al., 1998; Maricunga Belt, Chile: Muntean and Einaudi, 2001; Yanacocha, Peru: Longo et al., 2010; Bor, Serbia: Jankovic et al., 1980, Jankovic, 1990). In others, the enargite-bearing high-sulfidation polymetallic veins directly overprint the porphyry $\mathrm{Cu}$ mineralization (e.g., Chuquicamata, Chile: Ossandon et al., 2001, Rivera et al., 2012; Butte, USA: Meyer et al., 1968, Rusk et al., 2008, Reed et al., 2013; Nevados de Famatina, Argentina: Pudack et al., 2009; Rosia Poieni, Romania: Kouzmanov et al., 2010; Oyu Tolgoi, Mongolia: Crane and Kavalieris, 2012; Morococha, Peru: Catchpole et al., 2015). For some enargite-bearing high-sulfidation deposits no direct evidence for association with a porphyry system has been reported. However, such a genetic link has been suggested and strongly supported by a number of field and geochemical evidence (e.g., Colquijirca, Peru: Bendezu and Fontboté, 2009; Cerro de Pasco, Peru: Baumgartner et al., 2008; Chelopech, Bulgaria: Chambefort and Moritz, 2006, Chambefort et al., 2007). Therefore, an enargite-bearing high-sulfidation mineralization, when present, is considered to be an integral part of the upper portions of a porphyry $\mathrm{Cu}$ system sensu largo and to develop several hundred meters above the porphyry $\mathrm{Cu}$ centre (Sillitoe, 2010). Thus, the enargite-bearing deposits could be used as potential shallow-level indicators of a deeper porphyry system. Additionally, the enargite has been used as mineral approximator in the porphyry-centered districts: the closer to the porphyry- $\mathrm{Cu}$ center enargite is, the richer in $\mathrm{Au}, \mathrm{Te}$ and $\mathrm{V}$ it is (Deyell and Hedenquist, 2011). Based on these established relationships, we speculate that the enargite-luzonite mineralization at the summits of the North Su and Kaia Natai submarine volcanoes may provide evidences for concealed porphyry $\mathrm{Cu}(-\mathrm{Au})$ mineralization at depth. Enrichment in $\mathrm{Au}$, Te and V in the North Su enargite deposits (MN 01-12, J2-223-13-R1) relative to the Kaia Natai deposits (MN 03-11a) (Fig. 8; Table 4; Appendix 3) may imply that the inferred porphyry-Cu system beneath the North $\mathrm{Su}$ is shallower than that beneath the Kaia Natai [given similar hydrostatic pressure (depth of the seamount summits; Table 1) over the discharging hydrothermal systems]. From a theoretical point of view the studied enargite-luzonite deposits provide evidence that this high-sulfidation mineralization style can form at the seafloor [as volcanic-exhalative, Baksa (1975)] in addition to its broadly accepted replacement origin (Sillitoe, 1983). 


\section{Summary}

Investigated active and inactive chimneys from the North $\mathrm{Su}$ and Kaia Natai submarine volcanoes (East Manus Basin) are composed almost entirely of enargite and luzonite. The composition (at both a crystal and deposit scale) and crystal structure of these two major constituents of the studied deposits are similar to those of enargite and luzonite from other seafloor hydrothermal deposits and high-sulfidation epithermal deposits mined on land. The trace element composition of studied enargite and luzonite record the evolution of the deposit-forming fluid chemistry (increase of Fe, Ga, Tl, $\mathrm{Au}, \mathrm{Hg}, \mathrm{Pb}$ and Ag, and decrease of $\mathrm{Sb}, \mathrm{Sn}, \mathrm{Te}, \mathrm{Ge}$ and V concentrations) during chimney (flange) formation. It shows that this type of deposit is the richest in $\mathrm{Au}$ and Te among all other types of seafloor metal deposits. Enargite and luzonite precipitated inorganically, but mineralized mycelium-like network suggests that fungi living at the seafloor hydrothermal sites may be involved in a mechanism of bio-sequestration of $\mathrm{As}, \mathrm{S}$ and $\mathrm{Cu}$, and $\mathrm{Cu}$-sulphosalt precipitation. Inorganic precipitation of enargite-luzonite happened within a temperature range between $200^{\circ}$ and $330^{\circ} \mathrm{C}$ and at consistent long-term high $\mathrm{fS}_{2}$. Sulfur isotope composition of these minerals is negative $\left(\delta^{34} \mathrm{~S}=-8.58--3.70 \%\right.$ ) and is best explained by disproportionation of magmatic $\mathrm{SO}_{2}$. This suggests that the high $\mathrm{fS}_{2}$ required for enargite and luzonite precipitation is likely provided by direct magmatic input of $\mathrm{SO}_{2}$ into the hydrothermal system. Copper isotope composition $\left(\delta^{65} \mathrm{Cu}\right)$ of enargite-luzonite ranges from -0.20 to $+0.35 \%$. Its variation across the wall of an active chimney flange is interpreted to be associated with either Rayleigh-type fractionation, or redox processes $\left(\mathrm{Cu}^{+}\right.$oxidation to $\left.\mathrm{Cu}^{2+}\right)$ and the mass balance of dissolved $\mathrm{Cu}^{+}$and $\mathrm{Cu}^{2+}$ species in the hydrothermal fluid.

The investigated enargite-luzonite chimneys may be considered as submarine equivalents of subaerial high-sulfidation epithermal mineralization and potential indicators for concealed porphyry $\mathrm{Cu}(-\mathrm{Au})$ mineralization at depth.

\section{Acknowledgements}

This research was supported by the European Community as an Integrating Activity "Support of Public and Industrial Research Using Ion Beam Technology (SPIRIT)” (EC contract \#227012) and by a Marie Curie Intra European Fellowship (7th European Community Framework Program; grant \#253182, IsoBAB) to V. M. Dekov. O. Rouxel acknowledges the support from the Agence Nationale de la Recherche (France) through grant ANR-10- 
LABX-19-01. We appreciate the analytical help of "CRIST" (Centro Interdipartimentale di Cristallografia Strutturale, Sesto Fiorentino, Florence, Italy) for the single-crystal diffractometry, J. Langlade (CNRS, IFREMER) for the EMP analyses and E. Ponzevera (IFREMER) for the maintenance of the MC-ICP-MS at the Pôle Spectrometrie Ocean (IFREMER). Thanks go to M.K. Tivey (WHOI) for the fruitful discussions and for providing the sample from the MGLN06MV cruise. The paper benefited from comments by 2 anonymous reviewers and by the editor, David Hilton.

\section{References}

Adiwidjaja, G., Löhn, J., 1970. Strukturverfeinerung von Enargit, $\mathrm{Cu}_{3} \mathrm{AsS}_{4}$. Acta Crystallogr. B26, $1878-1879$.

Alfieris, D., Voudouris, P., Spry, P.G., 2013. Shallow submarine epithermal Pb-Zn-Cu-Au-Ag-Te mineralization on western Milos Island, Aegean Volcanic Arc, Greece: Mineralogical, geological and geochemical constraints. Ore Geol. Rev. 53, 159-180.

Alt, J.C., Shanks III, W.C., Jackson, M.C., 1993. Cycling of sulfur in subduction zones: The geochemistry of sulfur in the Mariana Island Arc and back-arc trough. Earth Planet. Sci. Lett. 119, 477-494.

Alt, J.C., Teagle, D.A.H., Brewer, T.S., Shanks, W.C. III, Halliday, A.N., 1998. Alteration and mineralization of an oceanic forearc and the ophiolite-ocean crust analogy. J. Geophys. Res. 103, 12,365-12,380.

Anbar, A.D., Rouxel, O., 2007. Metal stable isotopes in paleoceanography. Annu. Rev. Earth Planet. Sci. 35, 717746.

Arevalo Jr., R., McDonough, W.F., 2010. Chemical variations and regional diversity observed in MORB. Chem. Geol. 271, 70-85.

Arnold, M., Sheppard, S.M.F., 1981. East Pacific Rise at latitude $21^{\circ} \mathrm{N}$ : isotopic composition and origin of the hydrothermal sulfur. Earth Planet. Sci. Lett. 56, 148-156.

Arribas, Jr. A., 1995. Characteristics of high-sulfidation epithermal deposits, and their relation to magmatic fluid. In: Thompson, J.F.H. (Ed.), Magmas, Fluids, and Ore Deposits. Mineralogical Association of Canada, Victoria, British Columbia, pp. 419-454.

Asael, D., Matthews, A., Bar-Matthews, M., Halicz, L., 2007. Copper isotope fractionation in sedimentary copper mineralization (Timna Valley, Israel). Chem. Geol. 243, 238-254.

Asael, D., Matthews, A., Oszczepalski, S., Bar-Matthews, M., Halicz, L., 2009. Fluid speciation controls of low temperature copper isotope fractionation applied to the Kupferschiefer and Timna ore deposits. Chem. Geol. 262, 147-158.

Ashley, R.P., 1982. Occurrence model for enargite-gold deposits. In: Erickson, R.L. (Ed.), Characteristics of Mineral Deposit Occurrences. USGS Open-File Report 82-0795, 144-147.

Auzende, J.-M., Ishibashi, J., Beaudoin, Y., Charlou, J.-L., Delteil, J., Donval, J.-P., Fouquet, Y., Gouillou, J.-P., Ildefonse, B., Kimura, H., Nishio, Y., Radford-Knoery, J., Ruellan, E., 2000. MANAUTE Cruise Report, pp. 136. 
Bach, W., Roberts, S., Vanko, D.A., Binns, R.A., Yeats, C.J., Craddock, P.R., Humphris, S.E., 2003. Controls of fluid chemistry and complexation on rare-earth element contents of anhydrite from the Pacmanus subseafloor hydrothermal system, Manus Basin, Papua New Guinea. Miner. Deposita 38, 916-935.

Baksa, C., 1975. New data on the enargite-luzonite-pyrite massive sulphide deposits, north from Lahóca-Hill, Recsk. Hungarian Geol. Soc. Bull. 105, 58-74.

Baumgartner, R., Fontboté, L., Vennemann, T., 2008. Mineral zoning and geochemistry of epithermal polymetallic Zn-Pb-Ag-Cu-Bi mineralization at Cerro de Pasco, Peru. Econ. Geol. 103, 493-537.

Bendel, V., 1993. Cadre géologique et composition des minéralisations hydrothermales en contexte arrière-arc. Exemple de la dorsale du Bassin Nord Fijien (sud-ouest Pacifique). Unpublished Ph.D. thesis, University of Brest, $259 \mathrm{p}$.

Bendel, V., Fouquet, Y., Auzende, J.-M., Lagabrielle, Y., Grimaud, D., Urabe, T., 1993. The White Lady hydrothermal field, North Fiji back-arc basin, southwest Pacific. Econ. Geol. 88, 2237-2249.

Bendezú, R., 2007. Shallow polymetallic and precious metal mineralization associated with a Miocene diatremedome complex: the Colquijirca district in the Peruvian Andes. Ph.D. thesis, Université de Genève, Section des Sciences de la Terre, Terre et Environnement 64, 221 p.

Bendezú, R., Fontboté, L., 2009. Cordilleran epithermal Cu-Zn-Pb-(Au-Ag) mineralization in the Colquijirca District, Central Peru: deposit-scale mineralogical patterns. Econ. Geol. 104, 905-944.

Ben Othman, D., Luck, J.M., Bodinier, J.L., Arndt, N.T., Albarède, F., 2006. Cu-Zn isotopic variations in the Earth's mantle. Geochim. Cosmochim. Acta 70, A46.

Bernardini, G.P., Tanelli, G., Trosti, R., 1973. Relazioni di fase nel sistema $\mathrm{Cu}_{3} \mathrm{AsS}_{4}-\mathrm{Cu}_{3} \mathrm{SbS}_{4}$. Rendiconti della Società Italiana di Mineralogia e Petrologia 29, 281-296.

Binns, R.A., 2006. Data report: Geochemistry of massive and semimassive sulfides from Site 1189, Ocean Drilling Program Leg 193. In: Barriga, F.J.A.S., Binns, R.A., Miller, D.J., and Herzig, P.M. (Eds.), Proc. ODP, Sci. Results, 193, 1-22.

Binns, R.A., Scott, S.D., 1993. Actively forming polymetallic sulfide deposits associated with felsic volcanic-rocks in the Eastern Manus Back-Arc Basin, Papua New Guinea. Econ. Geol. 88, 2226-2236.

Binns, R.A., Barriga, F.J.A.S., Miller, D.J., 2007. Leg 193 synthesis: anatomy of an active felsic-hosted hydrothermal system, eastern Manus Basin, Papua New Guinea. In: Barriga, F.J.A.S., Binns, R.A., Miller, D.J., and Herzig, P.M. (Eds.), Proc. ODP, Sci. Results, 193, 1-71.

Blumenberg, M., Seifert, R., Petersen, S., Michaelis, W., 2007. Biosignatures present in a hydrothermal massive sulfide from the Mid-Atlantic Ridge. Geobiology 5, 435-450.

Bluth, G.J., Ohmoto, H., 1988. Sulfide-sulfate chimneys on the East Pacific Rise, $11^{\circ}$ and $13^{\circ} \mathrm{N}$ latitudes. Part II: Sulfur isotopes. Can. Mineral. 26, 505-515.

Borrok, D.M., Wanty, R.B., Ridley, W.I., Wolf, R., Lamothe, P.J., Adams, M., 2007. Separation of copper, iron, and zinc from complex aqueous solutions for isotopic measurements. Chem. Geol. 242, 400-414.

Bove, D.J., Mast, M.A., Dalton, J.B., Wright, W.G., Yager, D.B., 2007. Major styles of mineralization and hydrothermal alteration and related solid- and aqueous-phase geochemical signatures. In: Church, S.E., von Guerard, P., Finger, S.E. (Eds), US Geological Survey Professional Paper 1651, 1, pp. 161-230. 
Burgaud, G., Le Calvez, T., Arzur, D., Vandenkoornhuyse, P., Barbier, G., 2009. Diversity of culturable marine filamentous fungi from deep-sea hydrothermal vents. Environ. Microbiol. 11, 1588-1600.

Burgaud, G., Arzur, D., Durand, L., Cambon-Bonavita, M.A., Barbier, G., 2010. Marine culturable yeasts in deepsea hydrothermal vents: species richness and association with fauna. FEMS Microbiol. Ecol. 73, 121-133.

Butler, I.B., Fallick, A.E., Nesbitt, R.W., 1998. Mineralogy, sulphur isotope geochemistry and the development of sulphide structures at the Broken Spur hydrothermal vent site, $29^{\circ} 10^{\prime} \mathrm{N}$, Mid-Atlantic Ridge. Journal of the Geological Society, London 155, 773-785.

Callac, N., Rouxel, O., Lesongeur, F., Liorzou, C., Bollinger, C., Pignet, P., Chéron, S., Fouquet, Y., RommevauxJestin, C., Godfroy, A., 2015. Biogeochemical insights into microbe-mineral-fluid interactions in hydrothermal chimneys using enrichment culture. Extremophiles 19, 597-617.

Catchpole, H., Kouzmanov, K., Putlitz, B., Seo, J.H., Fontboté, L., 2015. Zoned base metal mineralization in a porphyry system: Origin and evolution of mineralizing fluids in the Morococha district, Peru. Econ. Geol. 110, 39-71.

Cerpa, L.M., Bissig, T., Kyser, K., McEwan, C., Macassi, A., Rios, H.W., 2013. Lithologic controls on mineralization at the Lagunas Norte high-sulfidation epithermal gold deposit, northern Peru. Miner. Deposita 48, 653-673.

Chambefort, I., Moritz, R., 2006. Late Cretaceous structural control and alpine overprint of the high-sulfidation CuAu epithermal Chelopech deposit, Srednogorie belt, Bulgaria. Miner. Deposita 41, 259-280.

Chambefort, I., Moritz, R., von Quadt, A., 2007. Petrology, geochemistry and U-Pb geochronology of magmatic rocks from the high-sulphidation epithermal $\mathrm{Cu}-\mathrm{Au}$ Chelopech deposit, Srednogorie zone, Bulgaria. Miner. Deposita 42, 665-690.

Chen, C.-T.A., Zeng, Z., Kuo, F.-W., Yang, T.F., Wang, B.-J., Tu, Y.-Y., 2005. Tide-influenced acidic hydrothermal system offshore NE Taiwan. Chem. Geol. 224, 69-81.

Ciobanu, M.C., Burgaud, G., Dufresne, A., Breuker, A., Rédou, V., Ben Maamar, S., Gaboyer, F., VandenabeeleTrambouze, O., Lipp, J.S., Schippers, A., Vandenkoornhuyse, P., Barbier, G., Jebbar, M., Godfroy, A., Alain, K., 2014. Microorganisms persist at record depths in the subseafloor of the Canterbury Basin. ISME Journal 8, 1370-1380.

Corral, I., Cardellach, E., Canals, À., Corbella, M., Martín-Crespo, T., Vindel, E., 2010. Environment of ore deposition in the Cerro Quema gold-copper deposit (Azuero Peninsula, Panama). Revista de la Sociedad Española de Mineralogía 13, 69-70.

Craddock, P.R., 2009. Geochemical tracers of processes affecting the formation of seafloor hydrothermal fluids and deposits in the Manus back-arc basin. Ph. D. thesis, Massachusetts Institute of Technology-Woods Hole Oceanographic Institution, Woods Hole, MA, 370 pp.

Craddock, P.R., Rouxel, O.J., Ball, L.A., Bach, W., 2008. Sulfur isotope measurement of sulfate and sulfide by highresolution MC-ICP-MS. Chem. Geol. 253, 102-113.

Craddock, P.R., Bach, W., Seewald, J.S., Rouxel, O.J., Reeves, E., Tivey, M.K., 2010. Rare earth element abundances in hydrothermal fluids from the Manus Basin, Papua New Guinea: indicators of sub-seafloor hydrothermal processes in back-arc basins. Geochim. Cosmochim. Acta 74, 5494-5513. 
Crane, D., Kavalieris, I., 2012. Geologic overview of the Oyu Tolgoi porphyry Cu-Au-Mo deposits, Mongolia. Society of Economic Geologists Special Publication 16, 187-213.

Dekov, V.M., Savelli, C., 2004. Hydrothermal activity in the SE Tyrrhenian Sea: An overview of 30 years of research. Mar. Geol. 204, 161-185.

Dekov, V.M., Bindi, L., Burgaud, G., Petersen, S., Asael, D., Rédou, V., Fouquet, Y., Pracejus, B., 2013a. Inorganic and biogenic As-sulfide precipitation at seafloor hydrothermal fields. Mar. Geol. 342, 28-38.

Dekov, V.M., Rouxel, O., Asael, D., Hålenius, U., Munnik, F., 2013b. Native Cu from the oceanic crust: Isotopic insights into native metal origin. Chem. Geol. 359, 136-149.

de Ronde, C.E.J., Hannington, M.D., Stoffers, P., Wright, I.C., Ditchburn, R.G., Reyes, A.G., Baker, E.T., Massoth, G.J., Lupton, J.E., Walker, S.L., Greene, R.R., Soong, C.W.R., Ishibashi, J., Lebon, G.T., Bray, C.J., Resing, J.A., 2005. Evolution of a submarine magmatic-hydrothermal system: Brothers volcano, southern Kermadec Arc, New Zealand. Econ. Geol. 100, 1097-1133.

de Ronde, C.E.J., Massoth, G.J., Butterfield, D.A., Christenson, B.W., Ishibashi, J., Ditchburn, R.G., Hannington, M.D., Brathwaite, R.L., Lupton, J.E., Kamenetsky, V.S., Graham, I.J., Zellmer, G.F., Dziak, R.P., Embley, R.W., Dekov, V.M., Munnik, F., Lahr, J., Evans, L.J., Takai, K., 2011. Submarine hydrothermal activity and gold-rich mineralization at Brothers Volcano, Kermadec Arc, New Zealand. Miner. Deposita 46, 541-584.

Deyell, C.L., Hedenquist, J.W., 2011. Trace element geochemistry of enargite in the Mankayan District, Philippines. Econ. Geol. 106, 1465-1478.

Di Benedetto, F., Bernardini, G.P., Borrini, D., Emiliani, C., Cipriani, C., Danti, C., Caneschi, A., Gatteschi, D., Romanelli, M., 2002. Crystal chemistry of tertahedrite solid-solution: EPR and magnetic investigations. The Canadian Mineralogist 40, 837-847.

Di Benedetto, F., Da Pelo, S., Caneschi, A., Lattanzi, P., 2011. Chemical state of arsenic and copper in enargite: evidences from EPR and X-ray absorption spectroscopies, and SQUID megnetometry. N. Jb. Miner. Abh. $188,11-19$.

Douville, É., Charlou, J.-L., Donval, J.-P., Hureau, D., Appriou, P., 1999. As and Sb behaviour in fluids from various deep-sea hydrothermal systems. C.R. Acad. Sci. Paris, Earth and Planetary Sciences 328, 97-104.

Douville, E., Charlou, J.L., Oelkers, E.H., Bienvenu, P., Colon, C.F.J., Donval, J.P., Fouquet, Y., Prieur, D., Appriou, P., 2002. The rainbow vent fluids $\left(36^{\circ} 14^{\prime} \mathrm{N}, \mathrm{MAR}\right)$ : the influence of ultramafic rocks and phase separation on trace metal content in Mid-Atlantic Ridge hydrothermal fluids. Chem. Geol. 184, 37-48.

Duckworth, R.C., Knott, R., Fallick, A.E., Rickard, D., Murton, B.J., van Dover, C., 1995. Mineralogy and sulphur isotope geochemistry of the Broken Spur sulphides, $29^{\circ} \mathrm{N}$, Mid-Atlantic Ridge. In: Parson, L.M., Walker, C.L., Dixon, D.R. (Eds.), Hydrothermal Vents and Processes. Geol. Soc. Spec. Publ. 87, 175-189.

Edgcomb, V.P., Beaudouin, D., Gast, R., Biddle, J.F., Teske, A., 2011. Marine subsurface eukaryotes: the fungal majority. Environ. Microbiol. 13, 172-183.

Edwards, K.J., Bach, W., McCollom, T.M., Rogers, D.R., 2004. Neutrophilic iron-oxidizing bacteria in the ocean: Their habitats, diversity, and roles in mineral deposition, rock alteration, and biomass production in the deepsea. Geomicrobiology Journal 21, 393-404. 
Ehrlich, S., Butler, I., Halicz, L., Rickard, D., Oldroyd, A., Matthews, A., 2004. Experimental study of the copper isotope fractionation between aqueous $\mathrm{Cu}(\mathrm{II})$ and covellite, $\mathrm{CuS}$. Chem. Geol. 209, 259-269.

Einaudi, M.T., Hedenquist, J.W., Inan, E., 2003. Sulfidation state of fluids in active and extinct hydrothermal systems: transition from porphyry to epithermal environments. Soc. Econ. Geol. Sp. Publ. 10, 285-313.

Fouquet, Y., Auclair, G., Cambon, P., Etoubleau, J., 1988. Geological setting, mineralogical, and geochemical investigations on sulfide deposits near $13^{\circ} \mathrm{N}$ on the East Pacific Rise. Mar. Geol. 84, 145-178.

Fouquet, Y., Von Stackelberg, U., Charlou, J.-L., Erzinger, J., Herzig, P.M., Mühe, R., Wiedicke, M., $1993 \mathrm{a}$. Metallogenesis in back-arc environments: The Lau Basin example. Econ. Geol. 88, 2154-2181.

Fouquet, Y., Wafik, A., Cambon, P., Mevel, C., Meyer, G., Gente, P., 1993b. Tectonic setting and mineralogical and geochemical zonation in the Snake Pit sulfide deposit (Mid-Atlantic Ridge at $23^{\circ} \mathrm{N}$ ). Econ. Geol. 88, 20182036.

Fouquet, Y., Knott, R., Cambon, P., Fallick, A., Rickard, D., Desbruyeres, D., 1996. Formation of large sulfide mineral deposits along fast spreading ridges. Example from off-axial deposits at $12^{\circ} 43^{\wedge} \mathrm{N}$ on the East Pacific Rise. Earth Planet. Sci. Lett. 144, 147-162.

Fouquet, Y., Cambon, P., Etoubleau, J., Charlou, J.L., Ondréas, H., Barriga, F.J.A.S., Cherkashov, G., Semkova, T., Poroshina, I., Bohn, M., Donval, J.P., Henry, K., Murphy, P., Rouxel, O., 2010. Geodiversity of hydrothermal processes along the Mid-Atlantic Ridge and ultramafic-hosted mineralization: A new type of oceanic $\mathrm{Cu}-\mathrm{Zn}$ Co-Au volcanogenic massive sulfide deposit. In: Rona, P.A., Devey, C.W., Dyment, J., Murton, B.J. (Eds.), Diversity of Hydrothermal Systems on Slow Spreading Ocean Ridges. Geophysical Monograph 188, 321367.

Fujii, T., Moynier, F., Abe, M., Nemoto, K., Albarede, F., 2013. Copper isotope fractionation between aqueous compounds relevant to low temperature geochemistry and biology. Geochim. Cosmochim. Acta 110, 29-44.

Fujii, T., Moynier, F., Blichert-Toft, J., Albarede, F., 2014. Density functional theory estimation of isotope fractionation of $\mathrm{Fe}, \mathrm{Ni}, \mathrm{Cu}$, and $\mathrm{Zn}$ among species relevant to geochemical and biological environments. Geochim. Cosmochim. Acta 140, 553-576.

Gamo, T., Okamura, K., Charlou, J.L., Urabe, T., Auzende, J.M., Ishibashi, J., Shitashima, K., Chiba, H., 1997. Acidic and sulfate-rich hydrothermal fluids from the Manus back-arc basin, Papua New Guinea. Geology 25, 139-142.

García-Ruiz, J.M., Hyde, S.T., Carnerup, A.M., Christy, A.G., Van Kranendonk, M.J., Welham, N.J., 2003. Selfassembled silica-carbonate structures and detection of ancient microfossils. Science 302, 1194-1197.

Gemmell, J.B., Sharpe, R., 1998. Detailed sulfur-isotope investigation of the TAG hydrothermal mound and stockwork zone, $26^{\circ}$ N, Mid-Atlantic Ridge. In: Herzig, P.M., Humphris, S.E., Miller, D.J., Zierenberg, R.A. (Eds.), Proc. ODP, Sci. Results, College Station, TX, 158, pp. 71-84.

Gena, K.R., Chiba, H., Mizuta, T., Matsubaya, O., 2006. Hydrogen, oxygen and sulfur isotope studies of seafloor hydrothermal system at the Desmos Caldera, Manus Back-arc Basin, Papua New Guinea: An analogue of terrestrial acid hot crater-lake. Resour. Geol. 56, 183-190.

German, C.R., Von Damm, K.L., 2006. Hydrothermal processes. In: Elderfield, H. (Ed.), The Oceans and Marine Geochemistry. Treatise on Geochemistry vol. 6, pp. 181-222. 
Glynn, S., Mills, R.A., Palmer, M.R., Pancost, R.D., Severmann, S., Boyce, A.J., 2006. The role of prokaryotes in supergene alteration of submarine hydrothermal sulfides. Earth Planet, Sci. Lett. 244, 170-188.

Guillong, M., Meier, D.L., Allan, M.M., Heinrich, C.A., Yardley, B.W.D., 2008. SILLS: a Matlab-based program for the reduction of Laser Ablation ICP-MS data of homogeneous materials and inclusions. In: Sylvester, P. (Ed.), Laser-ablation-ICPMS in the earth sciences: current practices and outstanding issues. Mineralogical Association of Canada, Vancouver, B.C., 328-333.

Günther, D., Frischknecht, R., Heinrich, C.A., Kahlert, H.J., 1997. Capabilities of an Argon Fluoride 193 nm excimer laser for laser ablation inductively coupled plasma mass spectrometry microanalysis of geological materials. Journal of Analytical Atomic Spectrometry 12, 939-944.

Haest, M., Muchez, P., Petit, J.C.J., Vanhaecke, F., 2009. Cu isotope ratio variations in the Dikulushi Cu-Ag deposit, DRC: of primary origin or induced by supergene reworking? Econ. Geol. 104, 1055-1064.

Halbach, P., Nakamura, K., Washner, M., Lange, J., Sakai, H., Käselitz, L., Hansen, R.D., Yamano, M., Post, J., Prause, B., Seifert, R., Michaelis, W., Teichmann, F., Kinoshita, M., Märten, A., Ishibashi, J., Cserwinski, S., Blum, N., 1989. Probable modern analogue of Kuroko-type massive sulphide deposits in the Okinawa trough back-arc basin. Nature 338, 496-499.

Halbach, P., Pracejus, B., Märten, A., 1993. Geology and mineralogy of massive sulfide ores from the central Okinawa Trough, Japan. Econ. Geol. 88, 2210-2225.

Hannington, M.D., Scott, S.D., 1988. Mineralogy and geochemistry of an hydrothermal silica-sulfide-sulfate spire in the caldera of Axial-Seamount, Juan de Fuca Ridge. Can. Mineral. 26, 603-625.

Hannington, M.D., Herzig, P.M., Scott, S.D., 1990. Auriferous hydrothermal precipitates on the modern seafloor. In: Foster, R.P. (Ed.), Gold Metallogeny and Exploration. Blackie, Glasgow, 249-282.

Hannington, M., Herzig, P., Scott, S., Thompson, G., Rona, P., 1991. Comparative mineralogy and geochemistry of gold-bearing sulfide deposits on the mid-ocean ridges. Mar. Geol. 101, 217-248.

Hannington, M.D., Poulsen, K.H., Thompson, J.F.H., Sillitoe, R.H., 1999. Volcanogenic gold in the massive sulfide environment. In: Barrie, C.T. and Hannington, M.D. (Eds), Volcanic-associated massive sulfide deposits: processes and examples in modern and ancient settings. Rev. Econ. Geol. 8, 325-356.

Haymon, R.M., Kastner, M., 1981. Hot spring deposits on the East Pacific Rise at $21^{\circ}$ N: Preliminary descriptions of mineralogy and genesis. Earth Planet. Sci. Lett. 53, 363-381.

Heald, P., Foley, N.K., Hayba, D.O., 1987. Comparative anatomy of volcanic-hosted epithermal deposits: Acidsulfate and adularia-sericite types. Econ. Geol. 82, 1-26.

Hedenquist, J.W., Lowenstern, J.B., 1994. The role of magmas in the formation of hydrothermal ore- deposits. Nature 370, 519-527.

Hedenquist, J.W., Arribas, A., Reynolds, T.J., 1998. Evolution of an intrusion-centered hydrothermal system: Far Southeast-Lepanto porphyry and epithermal Cu-Au deposits, Philippines. Econ. Geol. 93, 373-404.

Hedenquist, J.W., Claveria, R.J.R., Villafuerte, G.P., 2001. Types of sulfide-rich epithermal deposits, and their affiliation to porphyry systems: Lepanto-Victoria-Far Southeast deposits, Philippines, as examples. In: ProExplo 2001, Congreso Internacional de Prospectores y Exploradores, p. 29. 
Hein, J.R., Koschinsky, A., Halliday, A.N., 2003. Global occurrence of tellurium-rich ferromanganese crusts and a model for the enrichment of tellurium. Geochim. Cosmochim. Acta 67, 1117-1127.

Heinrich, C.A., Pettke, T., Halter, W.E., Aigner-Torres, M., Audétat, A., Günther, D., Hattendorf, B., Bleiner, D., Guillong, M., Horn, I., 2003. Quantitative multi-element analysis of minerals, fluid and melt inclusions by laser-ablation inductively-coupled plasma mass- spectrometry. Geochim. Cosmochim. Acta 67, 3473-3497.

Hekinian, R., Fevrier, H., Bischoff, J.L., Picot, P., Shanks, W.C., 1980. Sulfide deposits from the East Pacific Rise near $21^{\circ}$ N. Science 207, 1433-1444.

Herzig, P.M., Becker, K.P., Stoffers, P., Bäcker, H., Blum, N., 1988. Hydrothermal silica chimney fields in the Galapagos Spreading Center at $86^{\circ}$ W. Earth Planet. Sci. Lett. 89, 261-272.

Herzig, P.M., Hannington, M.D., 1995. Polymetallic massive sulfides at the modern seafloor: A review. Ore Geol. Rev. 10, 95-115.

Herzig, P.M., Hannington, M.D., Arribas Jr., A., 1998a. Sulfur isotopic composition of hydrothermal precipitates from the Lau back-arc: implications for magmatic contributions to seafloor hydrothermal systems. Miner. Deposita 33, 226-237.

Herzig, P.M., Petersen, S., Hannington, M.D., 1998b. Geochemistry and sulfur-isotopic composition of the TAG hydrothermal mound, Mid-Atlantic Ridge, $26^{\circ}$ N. In: Herzig, P.M., Humphris, S.E., Miller, D.J., Zierenberg, R.A. (Eds.), Proc. ODP, Sci. Results, College Station, TX, 158, pp. 47-70.

Hoagland, P., Beaulieu, S., Tivey, M.A., Eggert, R.G., German, C., Glowka, L., Lin, J., 2010. Deep-sea mining of seafloor massive sulfides. Mar. Policy 34, 728-732.

Hodgkinson, M.R.S., Webber, A.P., Roberts, S., Mills, R.A., Connelly, D.P., Murton, B.J., 2015. Talc-dominated seafloor deposits reveal a new class of hydrothermal system. Nature Communications 6, Article number 10150.

Hopkinson, L., Roberts, S., Herrington, R., Wilkinson, J., 1998. Self-organization of submarine hydrothermal siliceous deposits: Evidence from the TAG hydrothermal mound, 26 N Mid-Atlantic Ridge. Geology 26, $347-$ 350.

Huber, J.A., Welch, D.M., Morrison, H.G., Huse, S.M., Neal, P.R., Butterfield, D.A., Sogin, M.L., 2007. Microbial population structures in the deep marine biosphere. Science 318, 97-100.

Iizasa, K., Fiske, R.S., Ishizuka, O., Yuasa, M., Hashimoto, J., Ishibashi, J., Naka, J., Horii, Y., Fujiwara, Y., Imai, A., Koyama, S., 1999. A Kuroko-type polymetallic sulfide deposit in a submarine silicic caldera. Science 283, 975-977.

Ishibashi, J., Yamanaka, T., Okamura, K., Gamo, T., Charlou, J.-L., Chiba, H., Shitashima, K., Takahashi, H., 1997. Geochemical studies of magmatic hydrothermal activity in the DESMOS cauldron, Manus back arc basin. JAMSTEC Journal of Deep Sea Research 13, 243-248.

Ivarsson, M., Bengtson, S., Belivanova, V., Stampanoni, M., Marone, F., Tehler, A., 2012. Fossilized fungi in subseafloor Eocene basalts. Geology 40, 163-166.

Iwaida, C., Ueno, H., 2005. Ore and gangue minerals of seafloor hydrothermal deposits in the Mariana trough. JAMSTEC Report of Research and Development 1, 1-12. 
Jankovic, S., 1990, Types of copper deposits related to volcanic environment in the Bor district, Yugoslavia. Geol. Rundsch. 79, 467-478.

Jankovic, S., Terzic, M., Aleksic, D., Karamata, S., Spasov, T., Jovanovic, M., Milicic, M., Miskovic, V., Grubic, A., Antonijevic, I., 1980. Metallogenic features of copper deposits in the volcano-itrusive complexes of the Bor district, Yugoslavia. In: Jankovic, S. and Sillitoe, R.H. (Eds.), European Copper Deposits. SGA Spec. Publ. 1, 42-49.

Jenner, F.E., O’Neill, H.St.C., Arculus, R.J., Mavrogenes, J.A., 2010. The magnetite crisis in the evolution of arcrelated magmas and the initial concentration of $\mathrm{Au}, \mathrm{Ag}$ and $\mathrm{Cu}$. J. Petrol. 51, 2445-2464.

Kase, K., Yamamoto, M., Shibata, T., 1990. Copper-rich sulfide deposit near $23^{\circ}$ N, Mid-Atlantic Ridge: chemical composition, mineral chemistry, and sulfur isotopes. In: Detrick, R., Honnorez, J., Bryan, W.B., Juteau, T., et al. (Eds.), Proc. ODP, Sci. Results, College Station, TX, 106/109, pp. 163-177.

Kerridge, J.F., Haymon, R.M., Kastner, M., 1983. Sulfur isotope systematics at the $21^{\circ} \mathrm{N}$ site, East Pacific Rise. Earth Planet. Sci. Lett. 66, 91-100.

Khashgerel, B.-E., Rye, R.O., Kavalieris, I., Hayashi, K.-I., 2009. The sericitic to advanced argillic transition: Stable isotope and mineralogical characteristics from the Hugo Dummett porphyry $\mathrm{Cu}-\mathrm{Au}$ deposit, Oyu Tolgoi District, Mongolia. Econ. Geol. 104, 1087-1110.

Kim, J., Lee, I., Lee, K.-Y., 2004. S, Sr, and Pb isotopic systematic of hydrothermal chimney precipitates from the Eastern Manus Basin, western Pacific: Evaluation of magmatic contribution to hydrothermal system. J. Geophys. Res. 109, B12210, doi:10.1029/2003JB002912.

Kim, J., Lee, K.-Y., Kim, J.-H., 2011. Metal-bearing molten sulfur collected from a submarine volcano: Implications for vapor transport of metals in seafloor hydrothermal systems. Geology 39, 351-354.

Kimball, B.E., Mathur, R., Dohnalkova, A.C., Wall, A.J., Runkel, R.L., Brantley, S.L., 2009. Copper isotope fractionation in acid mine drainage. Geochim. Cosmochim. Acta 73, 1247-1263.

King, J., Williams-Jones, A.E., van Hinsberg, V., Williams-Jones, G., 2014. High-sulfidation epithermal pyritehosted $\mathrm{Au}(\mathrm{Ag}-\mathrm{Cu})$ ore formation by condensed magmatic vapors on Sangihe Island, Indonesia. Economic Geology 109, 1705-1733.

Klein, E.M., 2003. Geochemistry of the igneous oceanic crust. In: Rudnick, R.L. (Ed.), The Crust. Treatise on Geochemistry vol. 3, pp. 433-463.

Knott, R., Fallick, A.E., Rickard, D., Bäcker, H., 1995. Mineralogy and sulphur isotope characteristics of a massive

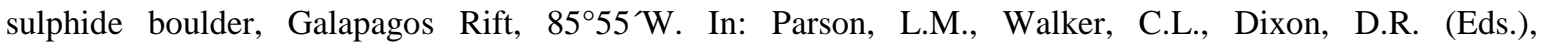
Hydrothermal Vents and Processes. Geol. Soc. Spec. Pub. 87, 207-222.

Kormas, K.A., Tivey, M.K., von Damm, K.L., Teske, A., 2006. Bacterial and archaeal phylotypes associated with distinct mineralogical layers of a white smoker spire from a deep-sea hydrothermal vent site $\left(9^{\circ} \mathrm{N}\right.$, East Pacific Rise). Environ. Microbiol. 8, 909-920.

Koski, R.A., Clague, D.A., Oudin, Ë., 1984. Mineralogy and chemistry of massive sulfide deposits from the Juan de Fuca Ridge. Geol. Soc. Am. Bull. 95, 930-945. 
Koski, R.A., Shanks, W.C. III, Bohrson, W.A., Oscarson, R.L., 1988. The composition of massive sulfide deposits from the sediment-covered floor of Escanaba Trough, Gorda Ridge: Implications for depositional processes. Can. Mineral. 26, 655-674.

Koski, R.A., Jonasson, I.R., Kadko, D.C., Smith, V.K., Wong, F.L., 1994. Compositions, growth mechanisms, and temporal relations of hydrothermal sulfide-sulfate-silica chimneys at the northern Cleft segment, Juan de Fuca Ridge. J. Geophys. Res. 99, B3, 4813-4832.

Kouzmanov, K., Ramboz, C., Bailly, L., Bogdanov, K., 2004. Genesis of high-sulphidation vinciennite-bearing CuAs-Sn ( $\pm \mathrm{Au})$ assemblage from the Radka epithermal copper deposit, Bulgaria: evidence from mineralogy and infrared microthermometry of enargite. Canadian Mineralogist 42, 1501-1521.

Kouzmanov, K., Pettke, T., Heinrich, C.A., 2010. Direct analysis of ore-precipitating fluids: combined IR microscopy and LA-ICP-MS study of fluid inclusions in opaque ore minerals. Econ. Geol. 105, 351-373.

Krasnov, S.G., Cherkashev, G.A., Stepanova, T.V., Batuyev, B.N., Krotov, A.G., Malin, B.V., Maslov, M.N., Markov, V.F., Poroshina, I.M., Samovarov, M.S., Ashadze, A.M., Lazareva, L.I., Ermolayev, I.K., 1995. Detailed geological studies of hydrothermal fields in the North Atlantic. In: Parson, L.M., Walker, C.L., Dixon, D.R., (Eds.), Hydrothermal Vents and Processes. Geological Society Special Publication 87, 43-64.

Kusakabe, M., Mayeda, S., Nakamura, E., 1990. S, O and Sr isotope systematics of active vent materials from the Mariana backarc basin spreading axis at $18^{\circ} \mathrm{N}$. Earth Planet. Sci. Lett. 100, 275-282.

Labidi, J., Cartigny, P., Birck, J.L., Assayag, N., Bourrand, J.J., 2012. Determination of multiple sulfur isotopes in glasses: A reappraisal of the MORB $\delta^{34}$ S. Chem. Geol. 334, 189-198.

Lange, I.M., Cheney, E.S., 1971. Sulfur isotopic reconnaissance of Butte, Montana. Econ. Geol. 66, 63-74.

Laznicka, P., 2010. Giant Metallic Deposits: Future Sources of Industrial Metals. Springer-Verlag, BerlinHeidelberg, 949 p.

Little, C.T.S., Glynn, S.E.J., Mills, R.A., 2004. Four-hundred-and-ninety-million-year record of bacteriogenic iron oxide precipitation at sea-floor hydrothermal vents. Geomicrobiology Journal 21, 415-429.

Longo, A.A., Dilles, J.H., Grunder, A.L., Duncan, R., 2010. Evolution of calc-alkaline volcanism and associated hydrothermal gold deposits at Yanacocha, Peru. Econ. Geol. 105, 1191-1241.

Lüders, V., Pracejus, B., Halbach, P., 2001. Fluid inclusion and sulfur isotope studies in probable modern analogue Kuroko-type ores from the JADE hydrothermal field (Central Okinawa Trough, Japan). Chem. Geol. 173, 4558.

Mancano, D.P., 1994. Microthermometry of enargite-hosted fluid inclusions from the Lepanto, Philippines, highsulfidation $\mathrm{Cu}-\mathrm{Au}$ deposit using infrared microscopy. Unpublished MSc thesis, New Mexico Institute of Mining and Technology, $74 \mathrm{p}$.

Mancano, D.P., Campbell, A.R., 1995. Microthermometry of enargite-hosted fluid inclusions from the Lepanto, Philippines, high-sulfidation Cu-Au deposit. Geochim. Cosmochim. Acta 59, 3909-3916.

Marchig, V., Puchelt, H., Rösch, H., Blum, N., 1990. Massive sulfides from ultra-fast spreading ridge, East Pacific Rise at $18-21^{\circ} \mathrm{S}$ : A geochemical stock report. Mar. Mining 9, 459-493.

Maréchal, C.N., Télouk, P., Albarède, F., 1999. Precise analysis of copper and zinc isotopic compositions by plasmasource mass spectrometry. Chem. Geol. 156, 251-273. 
Markl, G., Lahaye, Y., Schwinn, G., 2006. Copper isotopes as monitors of redox processes in hydrothermal mineralization. Geochim. Cosmochim. Acta 70, 4215-4228.

Martinez, F., Taylor, B., 1996. Backarc spreading, rifting, and microplate rotation, between transform faults in the Manus Basin. Marine Geophys. Res. 18, 203-224.

Maske, S., Skinner, B.J., 1971. Studies of the sulfosalts of copper: I. Phases and phase relations in the system Cu-AsS. Econ. Geol. 66, 901-918.

Mathur, R., Ruiz, J., Titley, S., Liermann, L., Buss, H., Brantley, S., 2005. Cu isotopic fractionation in the supergene environment with and without bacteria. Geochim. Cosmochim. Acta 69, 5233-5246.

Mathur, R., Titley, S., Barra, F., Brantley, S., Wilson, M., Phillips, A., Munizaga, F., Maksaev, V., Vervoort, J., Hart, G., 2009. Exploration potential of $\mathrm{Cu}$ isotope fractionation in porphyry copper deposits. J. Geochem. Explor. 102, 1-6.

Maydagán, L., Franchini, M., Lentz, D., Pons, J., McFarlane, C., 2013. Sulfide composition and isotopic signature of the Altar $\mathrm{Cu}-\mathrm{Au}$ deposit, Argentina: Constraints on the evolution of the porphyry-epithermal system. Can. Mineral. 51, 813-840.

Melekestseva, I.Yu., 2010. Sulfur isotopic composition of massive sulfides from the Semenov hydrothermal cluster, $13^{\circ} 31$ N, MAR. Minerals of the Ocean-5 and Deep-Sea Minerals and Mining-2 Joint International Conference, St. Petersburg, Russia, 28 June - 01 July 2010, Abstract Volume, pp. 70-73.

Metz, S., Trefry, J.H., 2000. Chemical and mineralogical influences on concentrations of trace metals in hydrothermal fluids. Geochim. Cosmochim. Acta 64, 2267-2279.

Meyer, C., Shea, E.P., Goddard, C.C., Jr., and Staff, 1968. Ore deposits at Butte, Montana. In: Ridge, J.D. (Ed.), Ore Deposits of the United States, 1933-67, 2. New York, American Institute of Mining, Metallurgical, and Petroleum Engineers, pp. 1373-1416.

Monecke, T., Giorgetti, G., Scholtysek, O., Kleeberg, R., Götze, J., Hannington, M.D., Petersen, S., 2007. Textural and mineralogical changes associated with the incipient hydrothermal alteration of glassy dacite at the submarine PACMANUS hydrothermal system, eastern Manus Basin. J. Volcanol. Geoth. Res. 160, 23-41.

Moritz, R., Benkhelfa, F., 2009. Fluids in high-sulfidation epithermal ore deposits: constraints from infrared microthermometry of enargite-hosted fluid inclusions. In: Williams, P., et al., (Eds), Smart science for exploration and mining, Proceedings of 10th Biennial SGA meeting, Townsville, Australia, August 2009, p. 533-535.

Moss, R., Scott, S.D., 2001. Geochemistry and mineralogy of gold-rich hydrothermal precipitates from the Eastern Manus basin, Papua New Guinea. Can. Mineral. 39, 957-978.

Moss, R., Scott, S.D., Binns, R.A., 2001. Gold content of Eastern Manus Basin volcanic rocks: Implications for enrichment in associated hydrothermal precipitates. Econ. Geol. 96, 91-107.

Muntean, J.L., Einaudi, M.T., 2001. Porphyry-epithermal transition: Maricunga belt, northern Chile. Econ. Geol. 96, 743-772.

Nercessian, O., Fouquet, Y., Pierre, C., Prieur, D., Jeanthon, C., 2005. Diversity of bacteria and archaea associated with a carbonate-rich metalliferous sediment sample from the Rainbow vent field on the Mid-Atlantic Ridge. Environ. Microbiol. 7, 608-714. 
Noll Jr., P.D., Newsom, H.E., Leeman, W.P., Ryan, J.G., 1996. The role of hydrothermal fluids in the production of subduction zone magmas: Evidence from siderophile and chalcophile trace elements and boron. Geochim. Cosmochim. Acta 60, 587-611.

Ono, S., Shanks III, W.C., Rouxel, O.J., Rumble, D., 2007. S-33 constraints on the seawater sulfate contribution in modern seafloor hydrothermal vent sulfides. Geochim. Cosmochim. Acta 71, 1170-1182.

Orsi, W.D., Edgcomb, V.P., Christman, G.D., Biddle, J.F., 2013. Gene expression in the deep biosphere. Nature 499, 205-208.

Ossandón, G., Fréraut, R., Gustafson, L.B., Lindsay, D.D., Zentilli, M., 2001. Geology of the Chuquicamata mine: A progress report. Econ. Geol. 96, 249-270.

Oudin, Ë., 1983. Hydrothermal sulfide deposits of the East Pacific Rise ( $\left.21^{\circ} \mathrm{N}\right)$. Part I: Descriptive mineralogy. Mar. Mining 4, 39-72.

Paris, G., Sessions, A.L., Subhas, A.V., Adkins, J.F., 2013. MC-ICP-MS measurement of $\delta^{34}$ S and $\Delta^{33}$ S in small amounts of dissolved sulfate. Chem. Geol. 345, 50-61.

Park, S.-H., Lee, S.-M., Kamenov, G.D., Kwon, S.-T., Lee, K.-Y., 2010. Tracing the origin of subduction components beneath the South East rift in the Manus Basin, Papua New Guinea. Chem. Geol. 269, 339-349.

Pattrick, R.A.D., van der Laan, G., Vaughan, D.J., Henderson, C.M.B., 1993. Oxidation state and electronic configuration determination of copper in tetrahedrite group minerals by L-edge X-ray absorption spectroscopy. Phys. Chem. Minerals 20, 395-401.

Perner, M., Kuever, J., Seifert, R., Pape, T., Koschinsky, A., Schmidt, K., Strauss, H., Imhoff, J.F., 2007. The influence of ultramafic rocks on microbial communities at the Logatchev hydrothermal field, located $15^{\circ} \mathrm{N}$ on the Mid-Atlantic Ridge. FEMS Microbiol. Ecol. 61, 97-109.

Peters, M., Strauss, H., Farquhar, J., Ockert, C., Eickmann, B., Jost, C.L., 2010. Sulfur cycling at the Mid-Atlantic Ridge: A multiple sulfur isotope approach. Chem. Geol. 269, 180-196.

Peters, M., Strauss, H., Petersen, S., Kummer, N.-A., Thomazo, C., 2011. Hydrothermalism in the Tyrrhenian Sea: Inorganic and microbial sulfur cycling as revealed by geochemical and multiple sulfur isotope data. Chem. Geol. 280, 217-231.

Petersen, S., Herzig, P.M., Schwarz-Schampera, U., Hannington, M.D., Jonasson, I.R., 2004. Hydrothermal precipitates associated with bimodal volcanism in the Central Bransfield Strait, Antarctica. Miner. Deposita 39, 358-379.

Petersen, S., Monecke, T., Westhues, A., Hannington, M.D., Gemmell, J.B., Sharpe, R., Peters, M., Strauss, H., Lackschewitz, K., Augustin, N., Gibson, H., Kleeberg, R., 2014. Drilling shallow-water massive sulfides at the Palinuro Volcanic Complex, Aeolian Island Arc, Italy. Econ. Geol. 109, 2129-2158.

Pfitzner, A., Bernert, T., 2004. The system $\mathrm{Cu}_{3} \mathrm{AsS}_{4}-\mathrm{Cu}_{3} \mathrm{SbS}_{4}$ and investigations on normal tetrahedral structures. Z. Kristallogr. 219, 20-26.

Pósfai, M., Buseck, P.R., 1998. Relationships between microstructure and composition in enargite and luzonite. Am. Mineral. 83, 373-382.

Pracejus, B., 2000. Re-Equilibrierungsprozesse einer rezenten submarinen Kuroko-Typ-Erzlagerstätte - Die Entwicklung der JADE-Massivsulfide im Okinawa-Trog. Habilitation thesis, Free University Berlin, 231 p. 
Pudack, C., Halter, W.E., Heinrich, C.A., Pettke, T., 2009. Evolution of magmatic vapor to gold-rich epithermal liquid: The porphyry to epithermal transition at Nevados de Famatina, northwest Argentina. Econ. Geol. 104, 449-477.

Rasmussen, B., 2000. Filamentous microfossils in a 3,235-million-year-old volcanogenic massive sulphide deposit. Nature 405, 676-679.

Reed, M.H., Rusk, B.G., Palandri, J., 2013. The Butte magmatic-hydrothermal system: One fluid yields all alteration and veins. Econ. Geol. 108, 1379-1396.

Reeves, E.P., Seewald, J.S., Saccocia, P., Bach, W., Craddock, P.R., Shanks, W.C., Sylva, S.P., Walsh, E., Pichler, T., Rosner, M., 2011. Geochemistry of hydrothermal fluids from the PACMANUS, Northeast Pual and Vienna Woods hydrothermal fields, Manus Basin, Papua New Guinea. Geochim. Cosmochim. Acta 75, 10881123.

Richards, J.P., 2011. Magmatic to hydrothermal metal fluxes in convergent and collided margins. Ore Geology Reviews 40, 1-26.

Rivera, S.L., Alcota, H., Proffett, J., Díaz, J., Leiva, G., Vergara, M., 2012. Update of the geologic setting and porphyry $\mathrm{Cu}-\mathrm{Mo}$ deposits of the Chuquicamata district, northern Chile. Society of Economic Geologists Special Publication 16, 19-54.

Roberts, S., Bach, W., Binns, R.A., Vanko, D.A., Yeats, C.J., Teagle, D.A.H., Blacklock, K., Blusztajn, J.S., Boyce, A.J., Cooper, M.J., Holland, N., McDonald, B., 2003. Contrasting evolution of hydrothermal fluids in the PACMANUS system, Manus Basin: The Sr and S isotope evidence. Geology 31, 805-808.

Rogers, D.R., Santelli, C.M., Edwards, K.J., 2003. Geomicrobiology of deep-sea deposits: estimating community diversity from low-temperature seafloor rocks and minerals. Geobiology 1, 109-117.

Rouxel, O., Fouquet, Y., Ludden, J.N., 2004a. Copper isotope systematics of the Lucky Strike, Rainbow, and Logatchev sea-floor hydrothermal fields on the Mid-Atlantic Ridge. Econ. Geol. 99, 585-600.

Rouxel, O., Fouquet, Y., Ludden, J.N., 2004b. Subsurface processes at the Lucky Strike hydrothermal field, MidAtlantic Ridge: Evidence from sulfur, selenium, and iron isotopes. Geochim. Cosmochim. Acta 68, 22952311.

Rouxel, O., Dekov, V.M., Asael, D., Tivey, M.K., 2016. Cu-isotope systematics of seafloor hydrothermal systems in Manus back-arc basin. (in prep.).

Rusk, B.G., Miller, B.J., Reed, M.H., 2008. Fluid inclusion evidence for the formation of Main Stage polymetallic base-metal veins, Butte, Montana, USA. Arizona Geological Society Digest 22, 573-581.

Sarrazin, J., Robigou, V., Juniper, S.K., Delaney, J.R., 1997. Biological and geological dynamics over four years on a high-temperature sulfide structure at the Juan de Fuca Ridge hydrothermal observatory. Mar. Ecol. Prog. Ser. 153, 5-24.

Scotney, P.M., Roberts, S., Herrington, R.J., Boyce, A.J., Burgess, R., 2005. The development of volcanic hosted massive sulfide and barite-gold orebodies on Wetar Island, Indonesia. Miner. Deposita 40, 76-99.

Scott, S.D., Binns, R.A., 1995. Hydrothermal processes and contrasting styles of mineralization in the western Woodlark and eastern Manus basins of the western Pacific. In: Parson, L.M., Walker, C.L., Dixon, D.R. (Eds), Hydrothermal Vents and Processes. Geol. Soc. London Sp. Pub. 87, pp. 191-205. 
Seewald, J.S., Reeves, E., Saccocia, P., Rouxel, O.J., Walsh, E., Price, R.E., Tivey, M., Bach, W., Tivey, M., 2006. Water-rock reaction, substrate composition, magmatic degassing, and mixing as major factors controlling vent fluid compositions in Manus Basin hydrothermal systems. EOS Transactions AGU Fall Meeting Supplement 87(52). Abstract \# B34A-02.

Seo, J.H., Lee, S.K., Lee, I., 2007. Quantum chemical calculations of equilibrium copper (I) isotope fractionations in ore-forming fluids. Chem. Geol. 243, 225-237.

Shanks, W.C., 2001. Stable isotopes in seafloor hydrothermal systems: Vent fluids, hydrothermal deposits, hydrothermal alteration, and microbial processes. In: Valley, J.W., Cole, D.R. (Eds), Stable Isotope Geochemistry. Rev. Mineral. Geochem. 43, pp. 469-525.

Shanks, W.C. III, Seyfried, W.E. Jr., 1987. Stable isotope studies of vent fluids and chimney minerals, southern Juan de Fuca Ridge. Sodium metasomatism and seawater sulfate reduction. J. Geophys. Res. 92, 11387-11399.

Shanks, W.C. III, Koski, R.A., Woodruff, L.G., 1984. Mineralogy and stable isotope systematics of sulfide deposits from the Juan de Fuca Ridge. EOS 65, 1113.

Sillitoe, R.H., 1983. Enargite-bearing massive sulfide deposits high in porphyry copper systems. Econ. Geol. 78, 348-352.

Sillitoe, R.H., 2010. Porphyry copper systems. Econ. Geol. 105, 3-41.

Sillitoe, R.H., Hannington, M.D., Thompson, J.F.H., 1996. High sulfidation deposits in the volcanogenic massive sulfide environment. Econ. Geol. 91, 204-212.

Simmons, S.F., White, N.C., John, D.A., 2005. Geological characteristics of epithermal precious and base metal deposits. Econ. Geol. 100 ${ }^{\text {th }}$ Anniversary Volume, 485-522.

Sinton, J.M., Ford, L.L., Chappell, B., Mcculloch, M.T., 2003. Magma genesis and mantle heterogeneity in the Manus backarc basin, Papua New Guinea. J. Petrol. 44, 159-195.

Skirrow, R., Coleman, M.L., 1982. Origin of sulfur and geothermometry of hydrothermal sulfides from the Galapagos Rift, $86^{\circ}$ N. Nature 299, 142-144.

Staude, J.-M.G., 1995. Epithermal mineralization in the Sierra Madre Occidental, and the metallogeny of northwestern Mexico. Ph.D. thesis, University of Arizona.

Stuart, F.M., Turner, G., Duckworth, R.C., Fallick, A.E., 1994. Helium isotopes as tracers of trapped hydrothermal fluids in ocean-floor sulfides. Geology 22, 823-826.

Stuart, F.M., Harrop, P.J., Knott, R., Fallick, A.E., Turner, G., Fouquet, Y., Rickard, D., 1995. Noble gas isotopes in 25000 years of hydrothermal fluids from $13^{\circ} \mathrm{N}$ on the East Pacific Rise. In: Parson, L.M., Walker, C.L., Dixon, D.R. (Eds.), Hydrothermal Vents and Processes. Geol. Soc. Spec. Publ. 87, 133-143.

Styrt, M.M., Brackmann, A.J., Holland, H.D., Clark, B.C., Pisutha-Arnold, V., Eldridge, C.S., Ohmoto, H., 1981. The mineralogy and the isotopic composition of sulfur in hydrothermal sulfide/sulfate deposits on the East Pacific Rise, $21^{\circ} \mathrm{N}$ latitude. Earth Planet. Sci. Lett. 53, 382-390.

Sutopo, B., Gemmell, J.B., Levet, B., 2007. Characteristics of sub-microscopic gold and trace element geochemistry of enargite/luzonite in the Martabe high-sulfidation epithermal deposits, North Sumatra, Indonesia. In: Andrew, C.J. et al. (Eds), Digging Deeper. Proceedings of the $9^{\text {th }}$ Biennial SGA Meeting, Dublin, Ireland, 20 23 August 2007. 773-776. 
Suzuki, R., Ishibashi, J.-I., Nakaseama, M., Konno, U., Tsunogai, U., Gena, K., Chiba, H., 2008. Diverse range of mineralization induced by phase separation of hydrothermal fluid: Case study of the Yonaguni Knoll IV hydrothermal field in the Okinawa trough back arc basin. Resour. Geol. 58, 267-288.

Taylor, B., 1979. Bismarck Sea: evolution of a back-arc basin. Geology 7, 171-174.

Thompson, C.M., Ellwood, M.J., Wille, M., 2013. A solvent extraction technique for the isotopic measurement of dissolved copper in seawater. Anal. Chim. Acta 775, 106-113.

Tivey, M.K., 1995. Modeling chimney growth and associated fluid flow at seafloor hydrothermal vent sites. In: Humphris, S.E., Zierenberg, R.A., Mullineaux, L.S., Thomson, R.E. (Eds.), Seafloor Hydrothermal Systems: Physical, Chemical, Biological, and Geological Interactions. American Geophysical Union, pp. 158-177.

Tivey, M.A., Bach, W., Seewald, J.S., Tivey, M.K., Vanko, D.A. and Shipboard Science and Technical Teams. 2007. Cruise Report R/V Melville, MAGELLAN-06. Hydrothermal systems in the Eastern Manus Basin: Fluid chemistry and magnetic structures as guides to subseafloor processes, Woods Hole Oceanographic Institution, pp. 67.

Tokeshi, M., 2011. Spatial structures of hydrothermal vents and vent-associated megafauna in the back-arc basin system of the Okinawa Trough, western Pacific. J. Oceanogr. 67, 651-665.

Toner, B.M., Santelli, C.M., Marcus, M.A., Wirth, R., Chan, C.S., McCollom, T., Bach, W., Edwards, K.J., 2009. Biogenic iron oxyhydroxide formation at mid-ocean ridge hydrothermal vents: Juan de Fuca Ridge. Geochim. Cosmochim. Acta 73, 388-403.

Vanko, D.A., Bach, W., Roberts, S., Yeats, C.J., Scott, S.D., 2004. Fluid inclusion evidence for subsurface phase separation and variable fluid mixing regimes beneath the deep-sea PACMANUS hydrothermal field, Manus Basin back arc rift, Papua New Guinea. J. Geophys. Res. 109, B03201.

Watanabe, M., Hoshino, K., Shiokawa, R., Takaoka, Y., Fukumoto, H., Shibata, Y., Shinjo, R., Oomori, T., 2006. Metallic mineralization associated with pillow basalts in the Yaeyama Central graben, southern Okinawa trough, Japan. JAMSTEC Report of Research and Development 3, 1-8.

Webber, A.P., Roberts, S., Murton, B.J., Hodgkinson, M.R.S., 2015. Geology, sulfide geochemistry and supercritical venting at the Beebe Hydrothermal Vent Field, Cayman Trough. Geochem. Geophys. Geosyst. 16, 26612678.

Wilson, S.A., Ridley, W.I., Koenig, A.E., 2002. Development of sulfide calibration standards for the laser ablation inductively- coupled plasma mass spectrometry technique. J. Anal. Atom. Spectrom. 17, 406-409.

Woodruff, L.G., Shanks, W.C., III., 1988. Sulfur isotope study of chimney minerals and vent fluids from $21^{\circ}$ N, East Pacific Rise: Hydrothermal sulfur sources and disequilibrium sulfate reduction. J. Geophys. Res. 93, 45624572.

Woods, A.W., Delaney, J.R., 1992. The heat and fluid transfer associated with the flanges on hydrothermal venting structures. Earth Planet. Sci. Lett. 112, 117-129.

Yeats, C.J., Binns, R.A., Parr, J.M., 2000. Advanced argillic alteration associated with actively forming, submarine polymetallic sulfide mineralization in the eastern Manus basin, Papua New Guinea. Geological Society of Australia Abstracts 59, p. 555. 
Zhu, X.K., Guo, Y., Williams, R.J.P., O’Nions, R.K., Matthews, A., Belshaw, N.S., Canters, G.W., de Waal, E.C., Weser, U., Burgess, B.K., Salvato, B., 2002. Mass fractionation processes of transition metal isotopes. Earth Planet. Sci. Lett. 200, 47-62.

Zierenberg, R.A., Shanks, W.C., III., Bischoff, J.L., 1984. Massive sulfide deposits at $21^{\circ}$ N, East Pacific Rise: chemical composition, stable isotopes, and phase equilibria. Geol. Soc. Am. Bull. 95, 922-929.

\section{Figure captions}

Fig. 1. Schematic map of the Manus Back-Arc Basin (SW Pacific) with North Su and Kaia Natai hydrothermal fields.

Fig. 2. (A) Active enargite-luzonite flange (white arrow) with overflowing fluid (black smoke) approached by the ROV Jason manipulator, transparent rhomb shows the position of the cross section shown at (B); (B) cross section of the enargite-luzonite flange (J2-223-13-R1) showing its structure: internal (a) and external (b) layers. Hot $\left(212^{\circ} \mathrm{C}\right)$, buoyant vent fluid is ponded bellow the lower concave surface of the flange, percolates (yellow dotted arrows) through the permeable flange wall, and overflows the flange lips [according to model of Woods and Delaney (1992)].

Fig. 3. Photomicrographs of: (A) clusters of finely lamellar luzonite (optical polarizing microscope, reflected light, $\times \mathrm{N}$, sample J2-223-13-R1); (B) euhedral enargite (en) and lamellar twinnings of luzonite (lzn) (optical polarizing microscope, reflected light, $\times \mathrm{N}$, sample $\mathrm{MN} 03-11 \mathrm{a}$ ); (C) bunches of skeletal luzonite crystals (BSE image, sample J2-223-13-R1); (D) close up of skeletal luzonite crystals (BSE image, sample J2-223-13-R1); (E) euhedral and colloform luzonite (lzn1 and lzn2, respectively) and late colloform marcasite (mc) (optical polarizing microscope, reflected light, \|N, sample MN 01-12); (F) marcasite (mc) and late colloform luzonite (lzn2), and euhedral luzonite (lzn1) (optical polarizing microscope, reflected light, $\| \mathrm{N}$, sample MN 01-12); (G) euhedral luzonite (lzn1), covellite (cvl) and late colloform marcasite (mc) (optical polarizing microscope, reflected light, $\| \mathrm{N}$, sample $\mathrm{MN} 01-12$ ); (H) covellite (cvl) and late luzonite (lzn) (optical polarizing microscope, reflected light, $\| \mathrm{N}$, sample MN 01-12).

Fig. 4. SEM photomicrographs (SEI; sample J2-223-13-R1) of: (A) clusters of luzonite crystals on barite; (B) clusters of luzonite crystals; (C) clusters of luzonite crystals, close up; (D) cluster of prismatic luzonite crystals.

Fig. 5. Photomicrographs (optical polarizing microscope, reflected light, $\| \mathrm{N}$, sample J2-223-13-R1) showing complex fungal-like structures (A-C) and putative preserved septum in a mineralized filament (D).

Fig. 6. BSE images and WDS X-ray maps of zoned enargite crystal (A, B, C: sample MN 03-11a) and dendritic luzonite aggregate (D, E, F: sample J2-223-13-R1). Concentrations of As and Sb on the maps increase from blue to red; EMP point analyses in different zones are indicated in wt.\%. 
Fig. 7. Electron microprobe data on enargite and luzonite from the Manus Back-Arc Basin: (A) As-Sb correlation diagram. The trend is slightly shifted down from the theoretical values due to non-stoichiometry of the composition; (B) Sb-Sn, and (C) Sb-Te correlation diagrams. Note the two correlation trends indicative of different substitution mechanisms in enargite and luzonite (see text for discussion).

Fig. 8. LA-ICP-MS data on trace element concentrations in luzonite and enargite from the Manus Back-Arc Basin.

Fig. 9. LA-ICP-MS trace element compositional profile along the axis of a complex luzonite dendritic aggregate(A, BSE image), illustrating core-to-rim zoning (B, C, D, E, F), reflecting changes of the ore-forming fluid chemistry over time.

Fig. 10. Sulfur-isotope composition (range) of hydrothermal sulfides from selected mid-ocean ridges [unsedimented (mafic- and ultramafic-hosted) and sedimented], volcanic arcs and back-arc basins, and of enargites from continental high-sulfidation epithermal deposits compared to that of studied enargite deposits. References: terrestrial mantle (Labidi et al., 2012), seawater (Paris et al., 2013), Galapagos Rift (Skirrow and Coleman, 1982; Knott et al., 1995), $21^{\circ} \mathrm{N}$ EPR (Hekinian et al., 1980; Arnold and Sheppard, 1981; Styrt et al., 1981; Kerridge et al., 1983; Zierenberg et al., 1984; Woodruff and Shanks, 1988; Stuart et al., 1994), 11-13 N EPR (Bluth and Ohmoto, 1988; Stuart et al.,

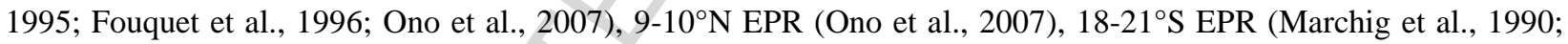
Ono et al., 2007), Lucky Strike (Rouxel et al., 2004a; Ono et al., 2007), Broken Spur (Duckworth et al., 1995; Butler et al., 1998), TAG (Stuart et al., 1994; Gemmell and Sharpe, 1998; Herzig et al., 1998b; Shanks, 2001), Snakepit (Kase et al., 1990; Stuart et al., 1994), Southern MAR (Peters et al., 2010), Rainbow (Rouxel et al., 2004a), Logatchev (Rouxel et al., 2004a; Peters et al., 2010), Semenov (Melekestseva, 2010), Red Sea (Shanks, 2001), Juan de Fuca (Shanks et al., 1984; Shanks and Seyfried, 1987; Hannington and Scott, 1988; Stuart et al., 1994), Escanaba Trough (Shanks, 2001), Guaymas Basin (Shanks, 2001), Okinawa Trough (Lüders et al., 2001), Izu-Bonin Arc (Alt et al., 1998), Mariana Trough (Kusakabe et al., 1990), Manus Basin (Kim et al., 2004), Lau Basin (Kim et al., 2011), Kermadec Arc (de Ronde et al., 2005; 2011), Aeolian Arc (Peters et al., 2011; Petersen et al., 2014), Lagunas Norte (Cerpa et al., 2013), Butte (Lange and Cheney, 1971), Colquijirca (Bendezú, 2007), Cerro de Pasco (Baumgartner et al., 2008), Altar (Maydagán et al., 2013), Sierra Madre Occidental (Staude, 1995), Lepanto (Mancano, 1994), Oyu Tolgoi (Khashgerel et al., 2009), Cerro Quema (Corral et al., 2010).

Fig. 11. Cross-section of the active enargite-luzonite flange (J2-223-13-R1) with positions and $\delta^{65} \mathrm{Cu}$ values of point analyses (MicroMill sampling; point numbers as in Table 6) along two transects and bulk powder analyses of internal (a) and external (b) layers. VF = vent fluid, $\mathrm{SW}=$ seawater; lzn = luzonite. Frequency distribution of $\delta^{65} \mathrm{Cu}$ values obtained via point analyses (MicroMill sampling; blue bars) and positions of $\delta^{65} \mathrm{Cu}$ values obtained on bulk powder samples (a and $\mathbf{b}$, red dashed lines). 
Fig. 12. Trace element distribution in enargite from the Manus Back-Arc Basin (sample MN 03-11a), compared to: (A) enargite from the Lepanto high-sulfidation epithermal deposit, Philippines (data from Deyell and Hedenquist, 2011); (B) enargite from sub-epithermal and epithermal veins in the Altar $\mathrm{Cu}-\mathrm{Au}$ porphyry-epithermal system, Argentina (data from Maydagán et al., 2013); (C) enargite from high-sulfidation epithermal mineralization on Sangihe Island, Indonesia (data from King et al., 2014).

Fig. 13. Calculated $\mathrm{Eh}-\mathrm{pH}$ diagrams for the $\mathrm{Cu}$-chloride speciation system at $\mathrm{T}, \mathrm{p}$ and fluid chemistry conditions of the internal flange layer a (A) and external flange layer b (B) (sample J2-223-13-R1). See 5.5 for details of the calculations and choice of parameters values.
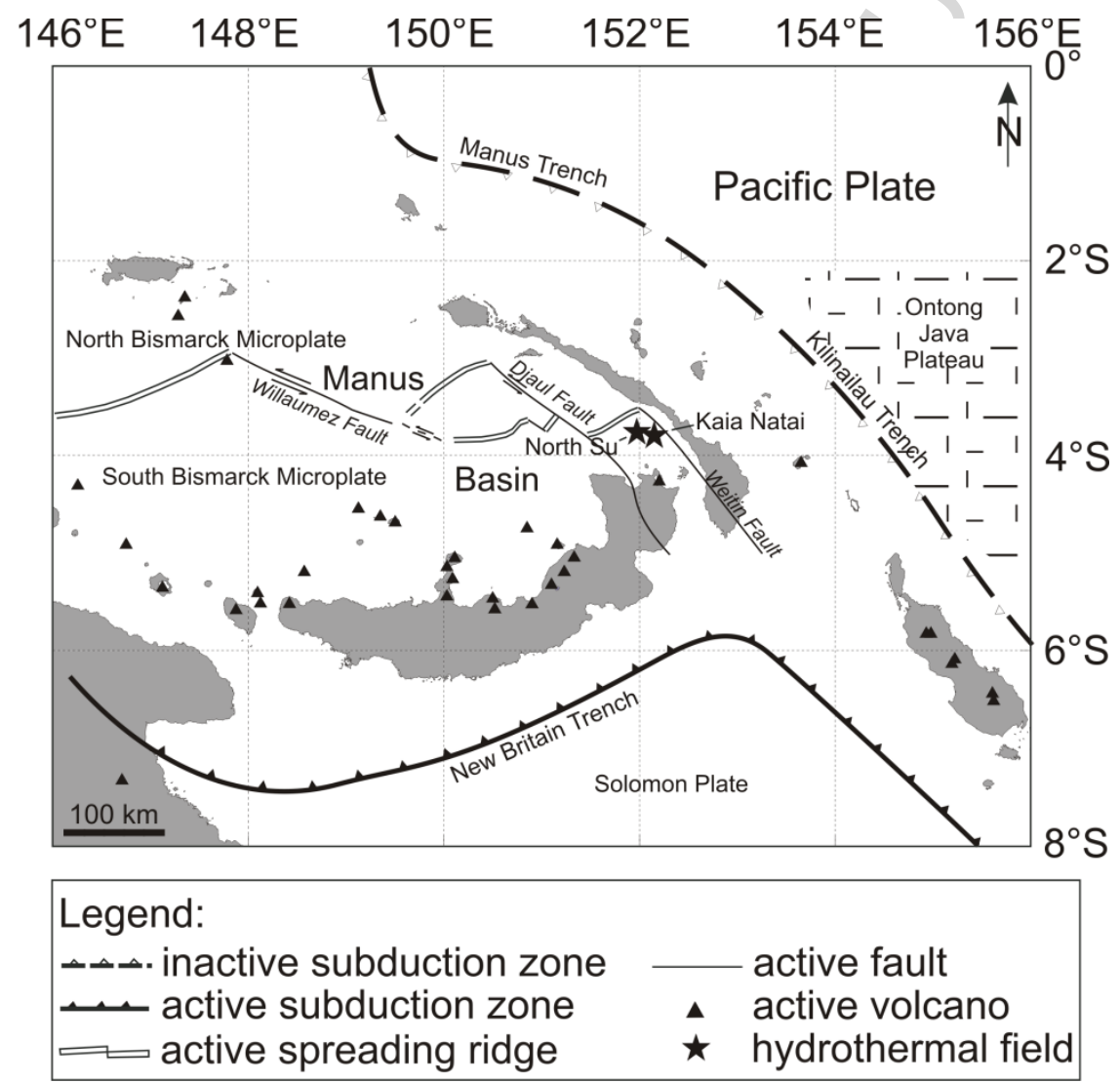

Fig. 1 


\section{ACCEPTED MANUSCRIPT}
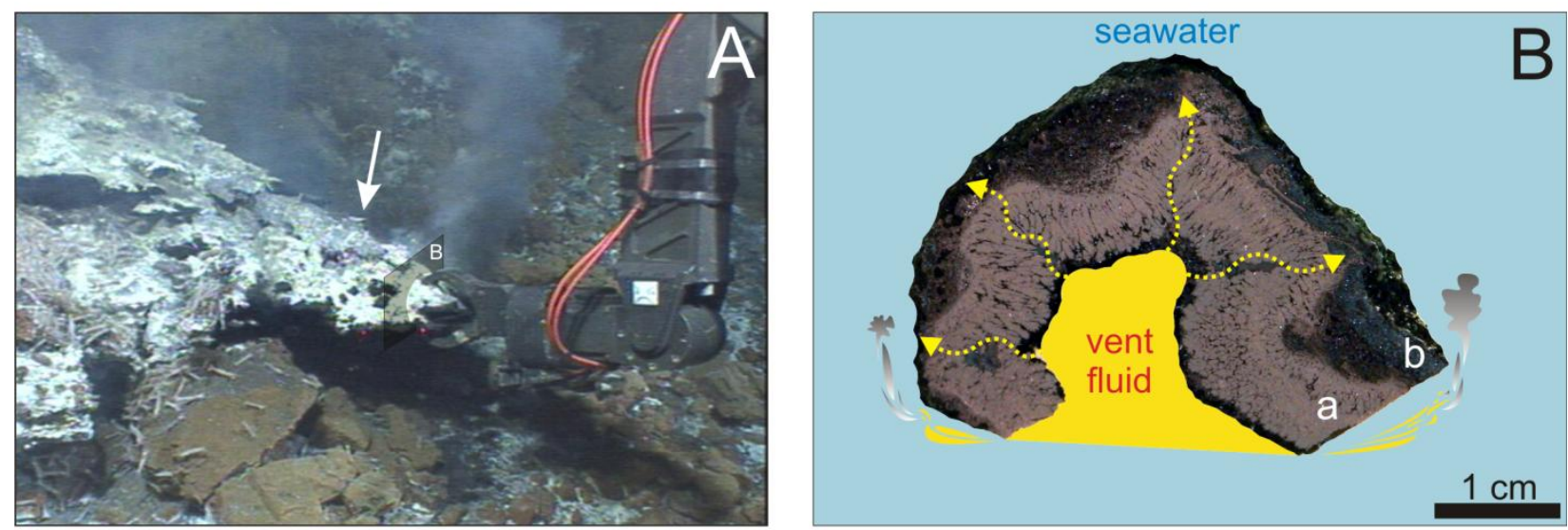

Fig. 2 

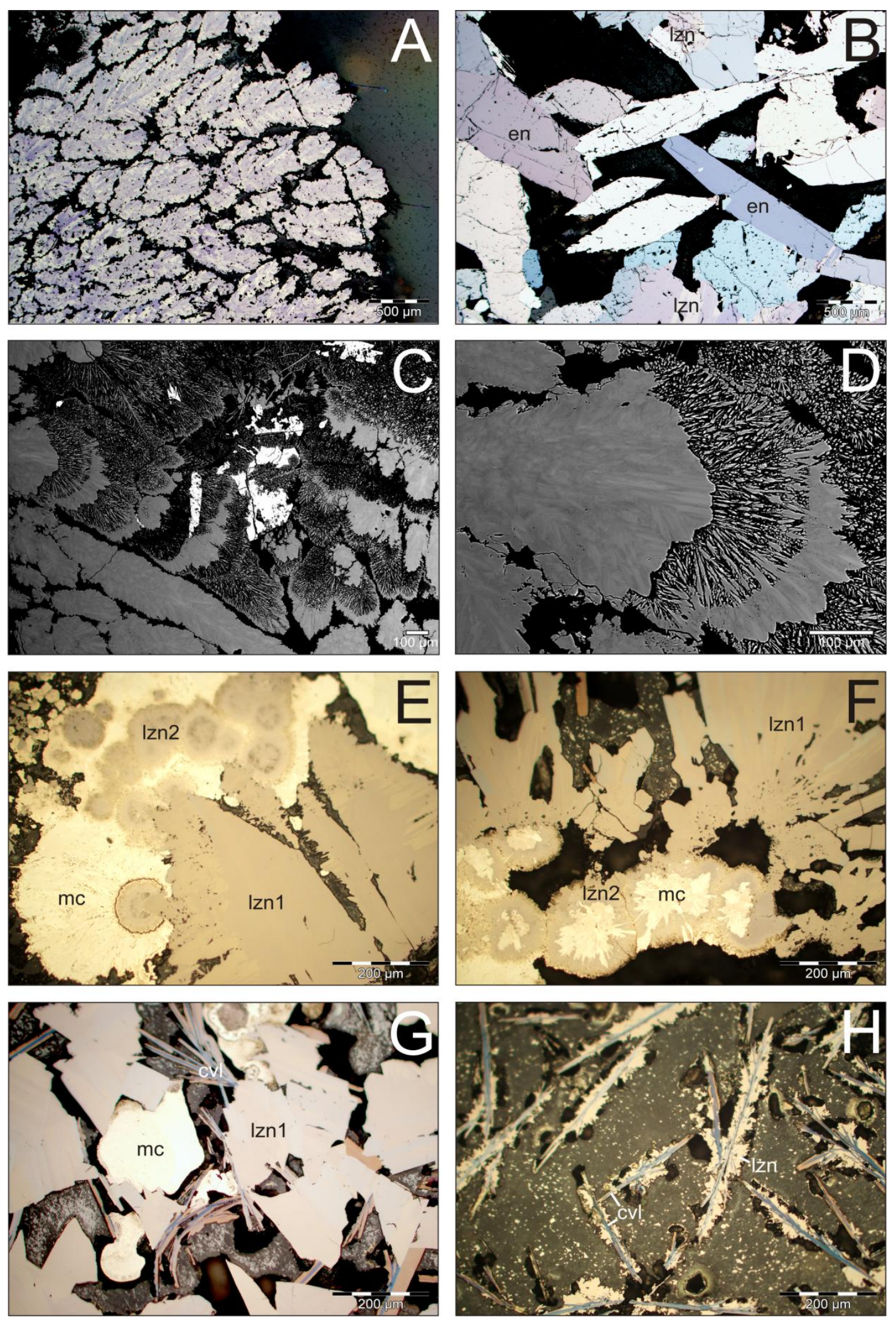

Fig. 3 

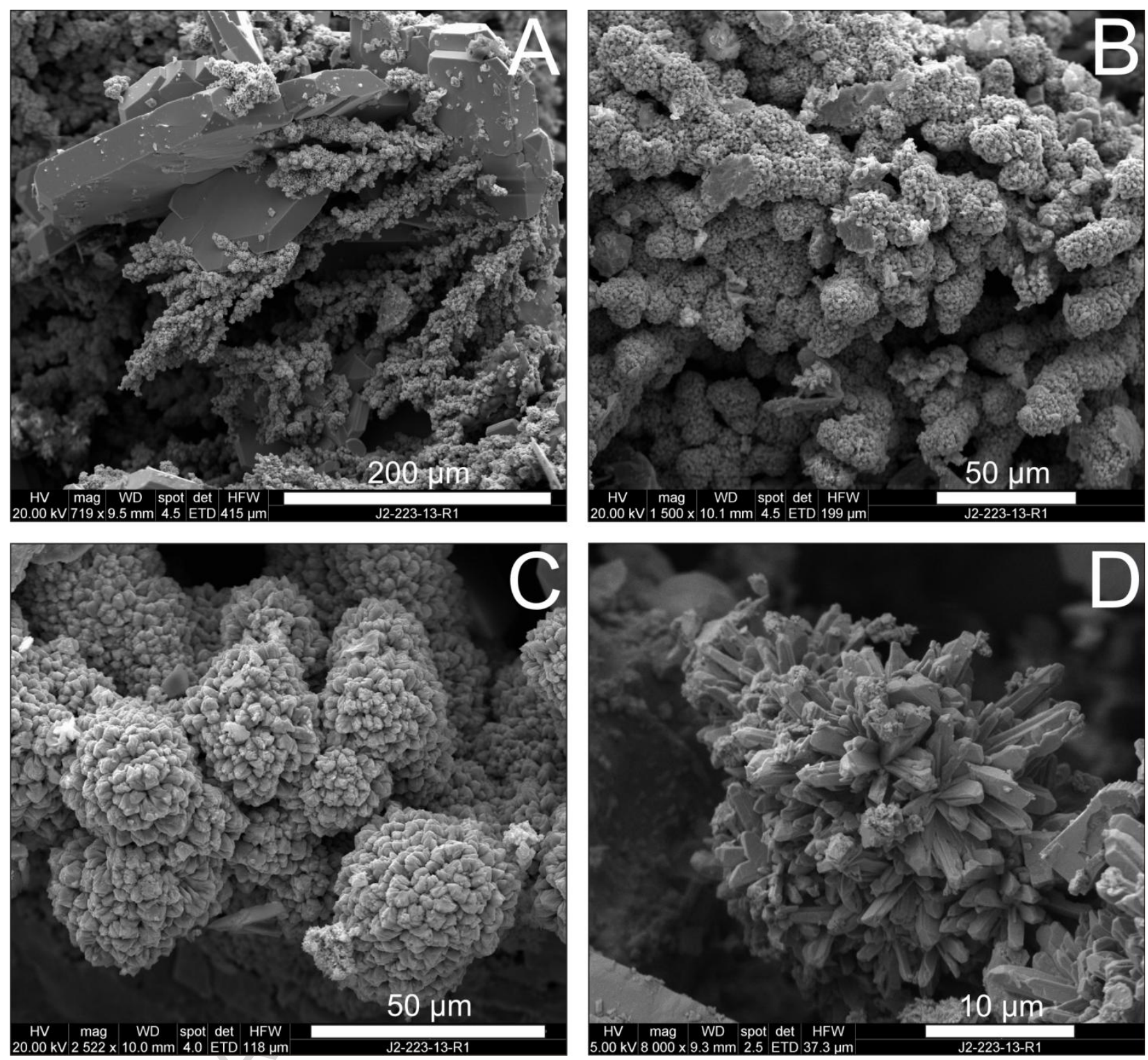

Fig. 4 

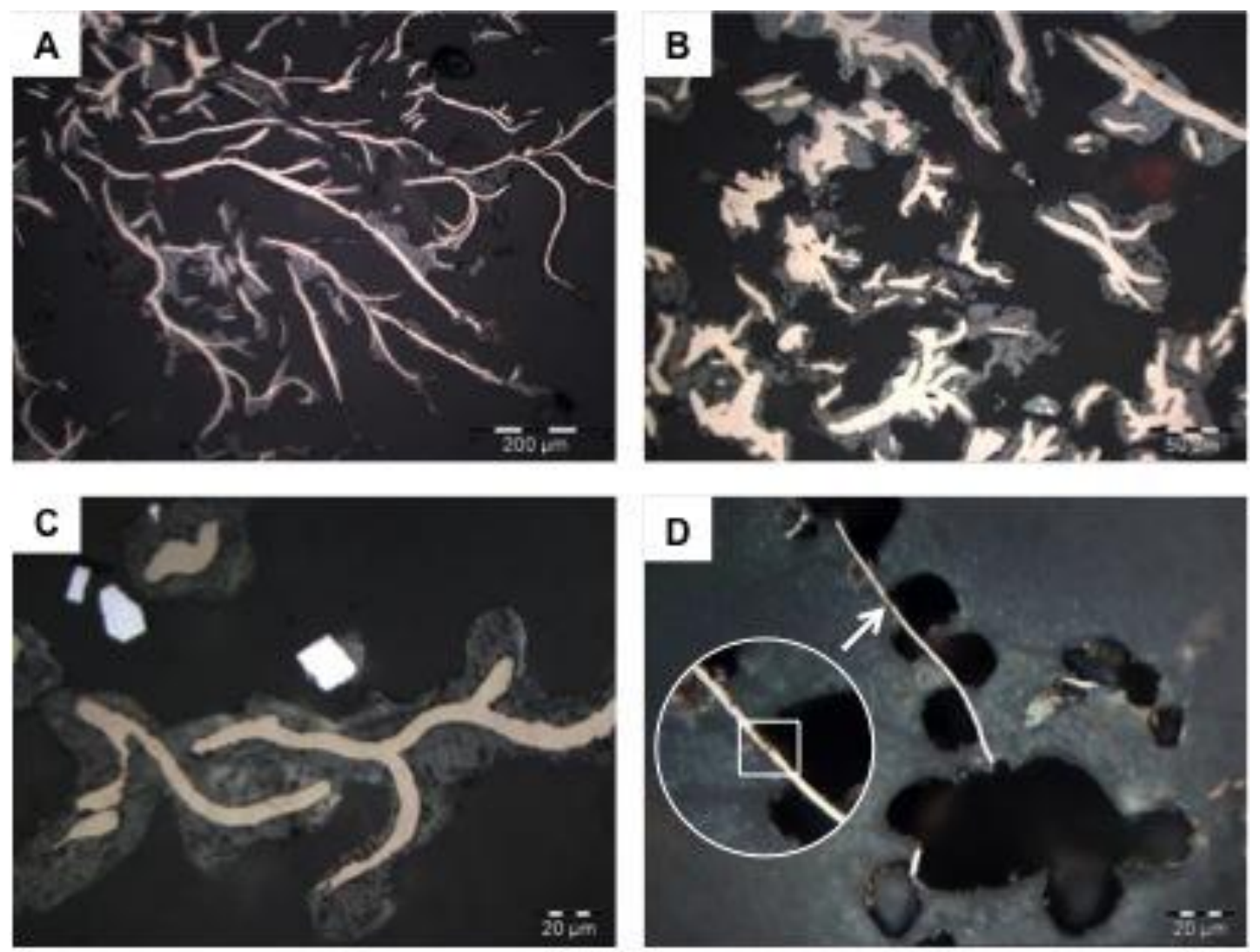

Fig. 5 

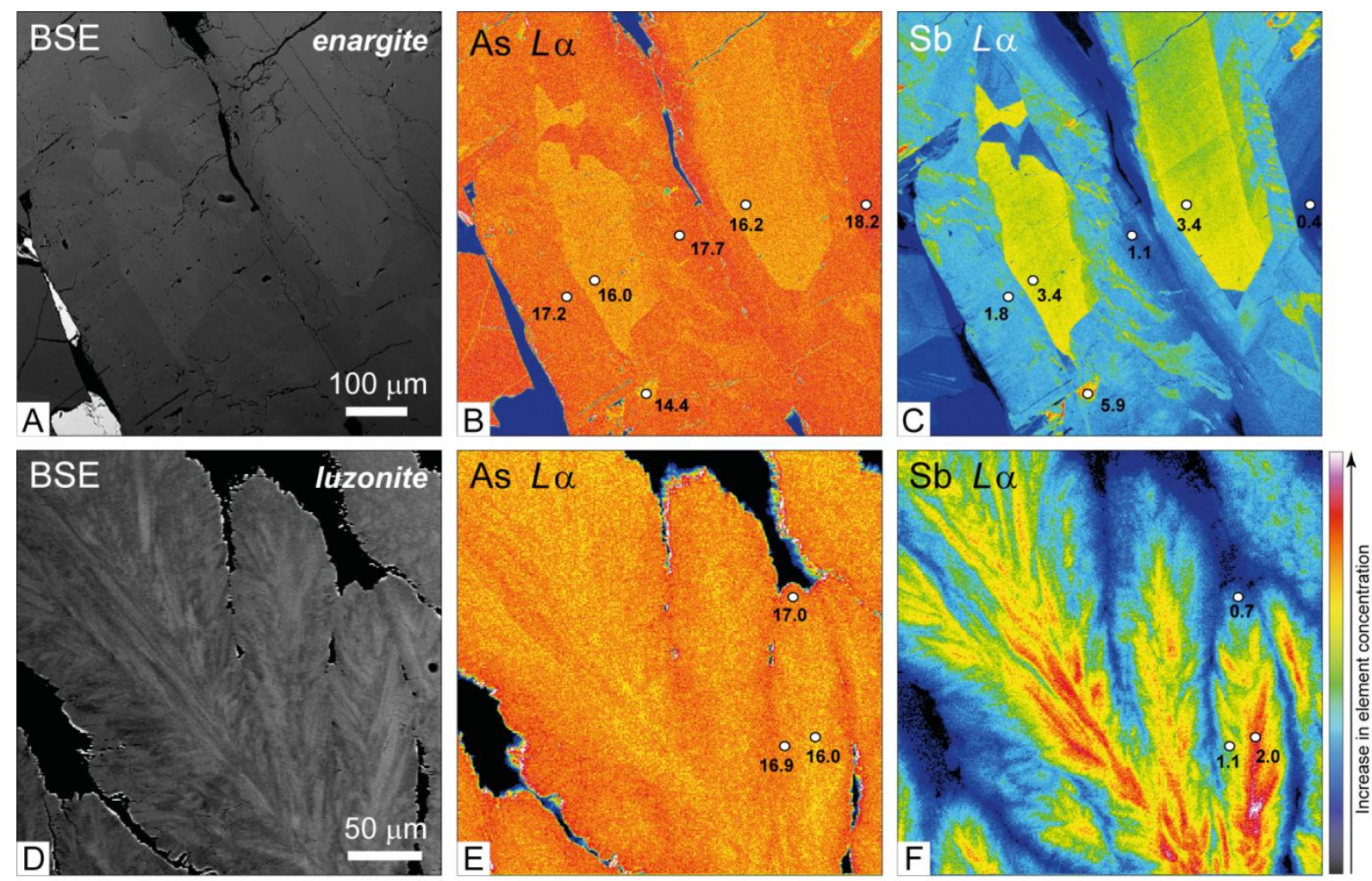

Fig. 6 

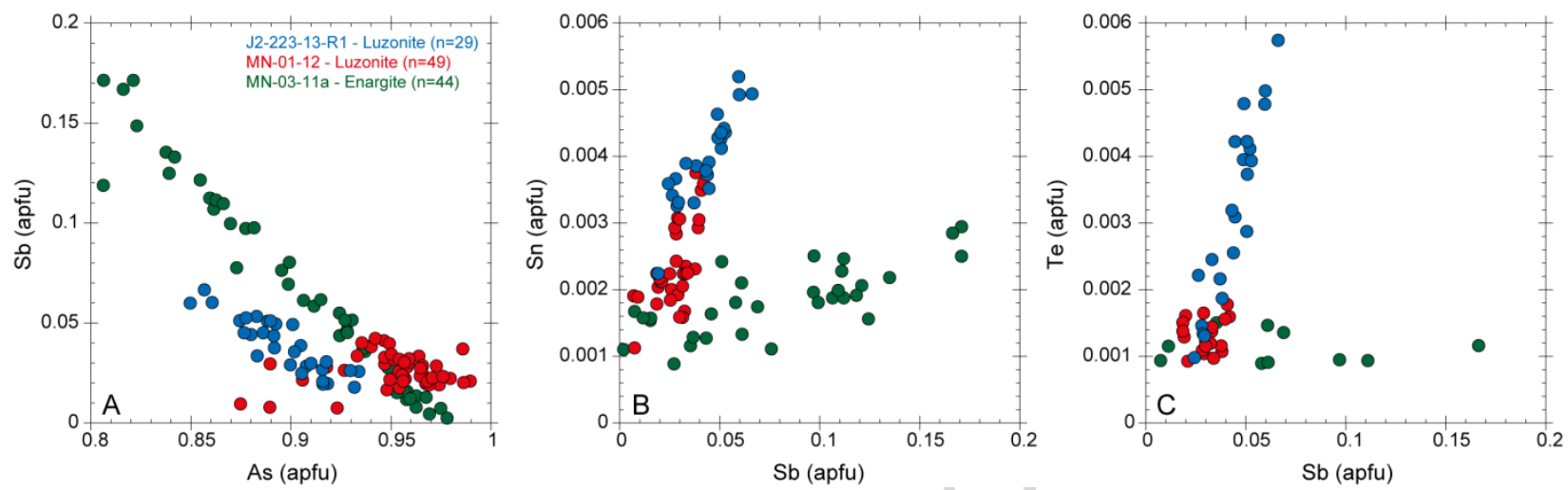

Fig 7

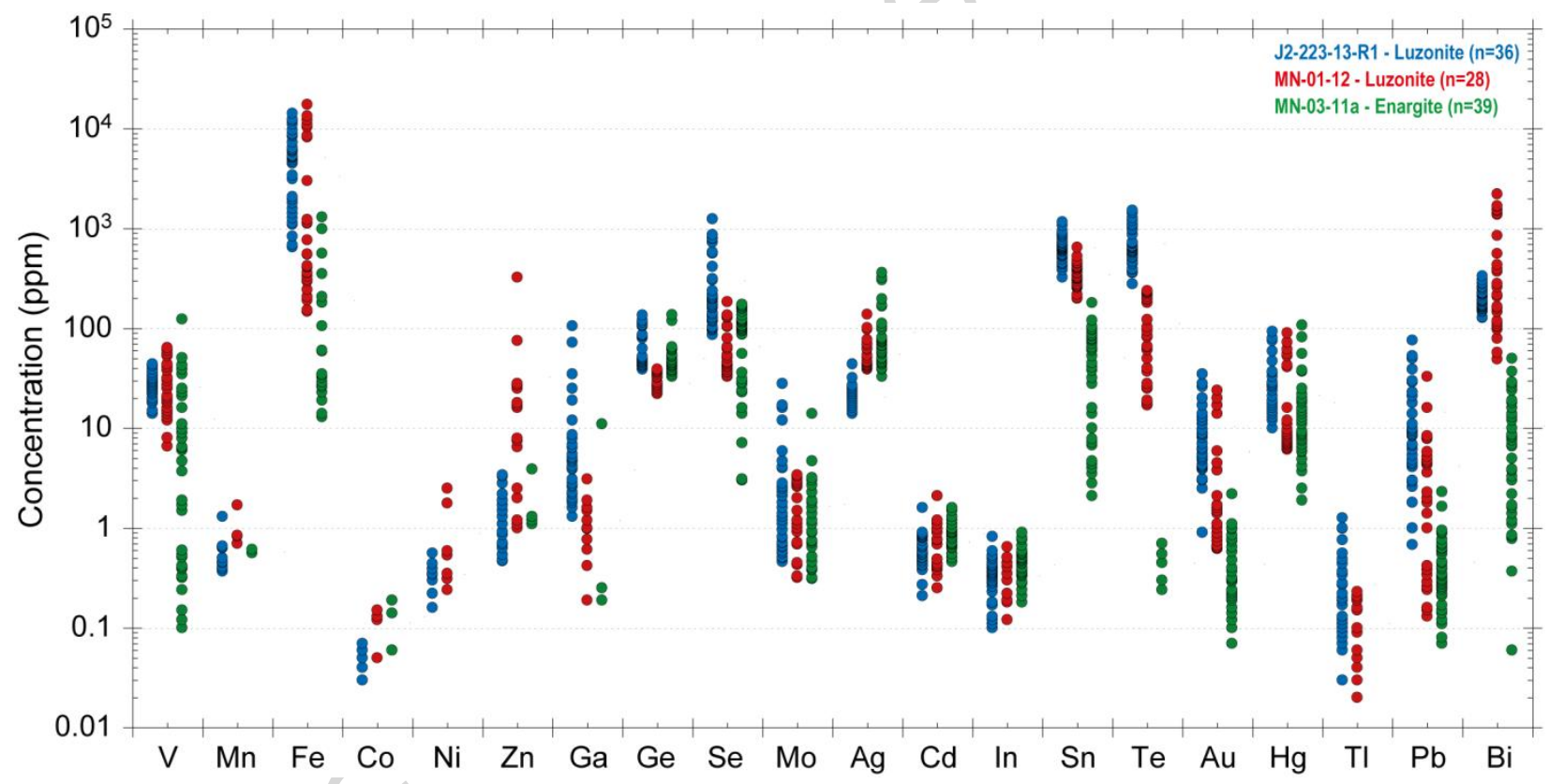

Fig. 8 

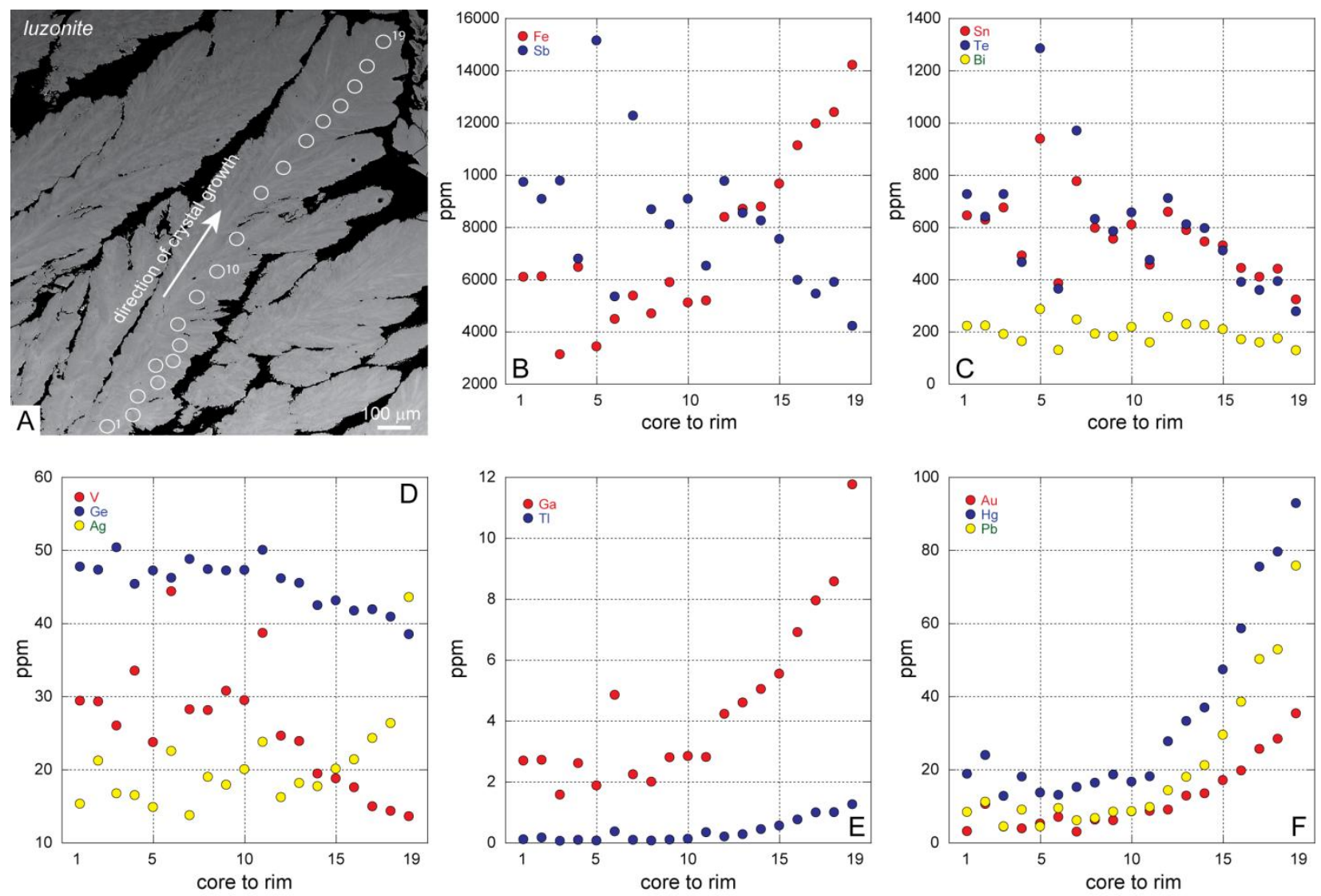

Fig. 9 


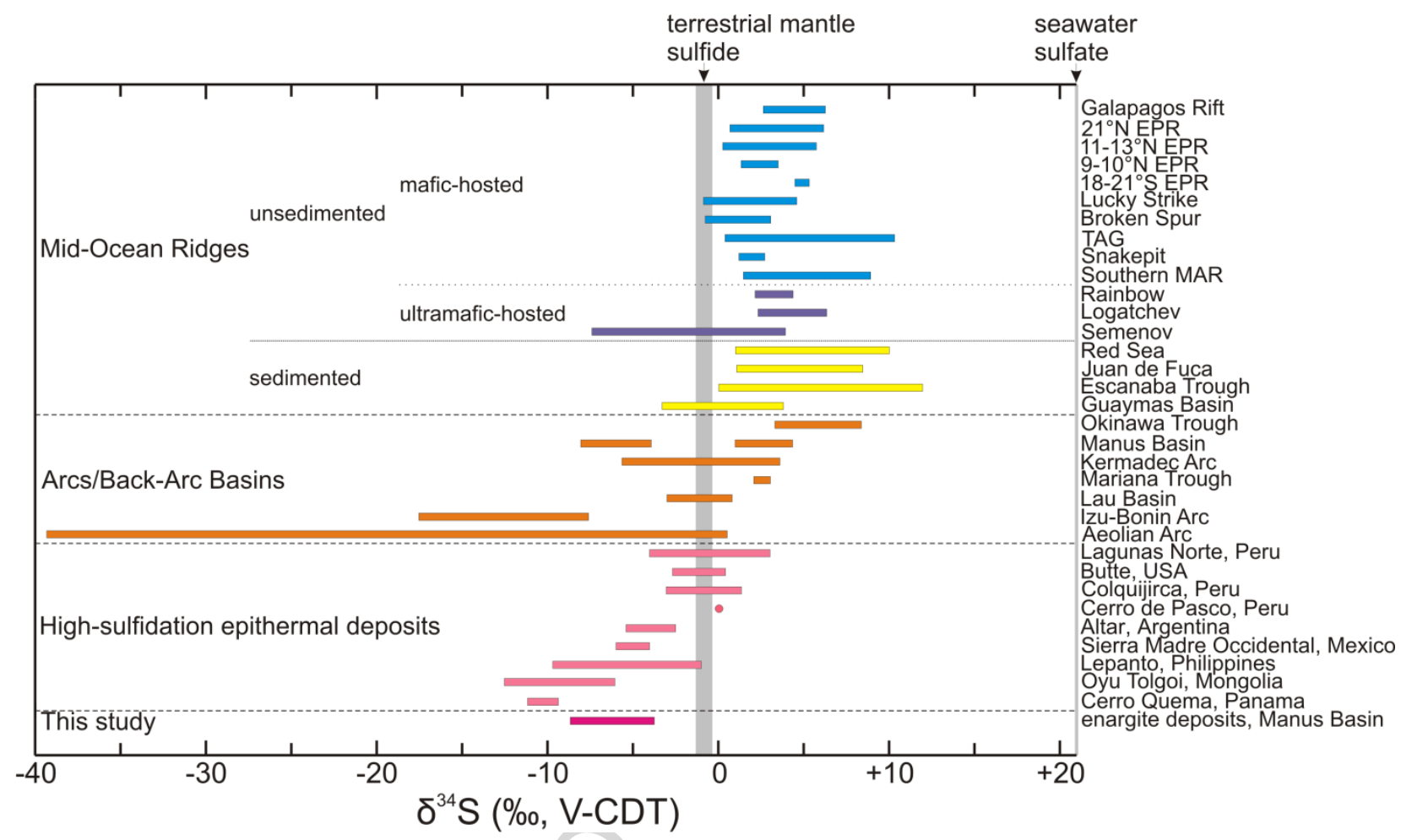

Fig. 10 


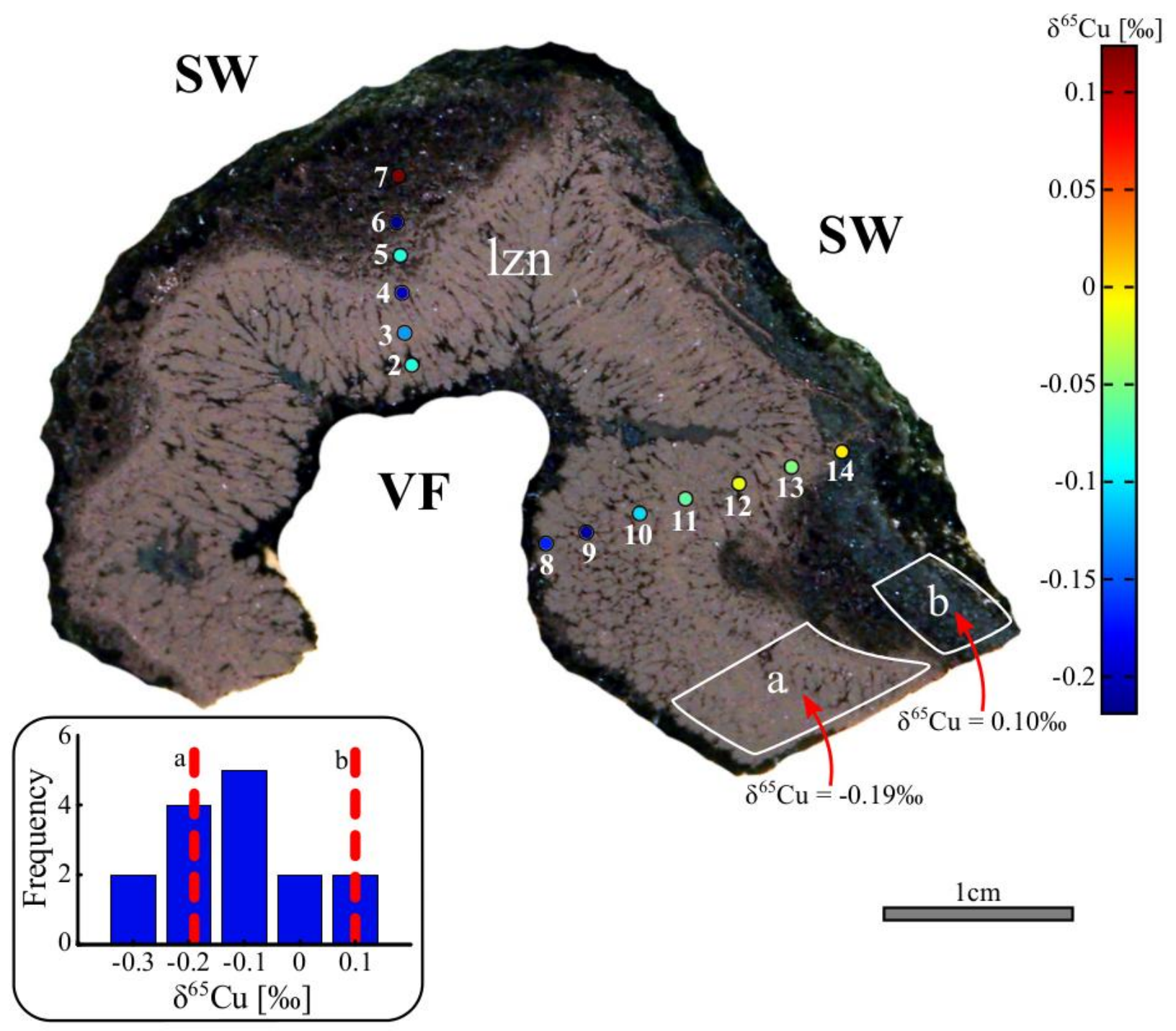

Fig. 11 


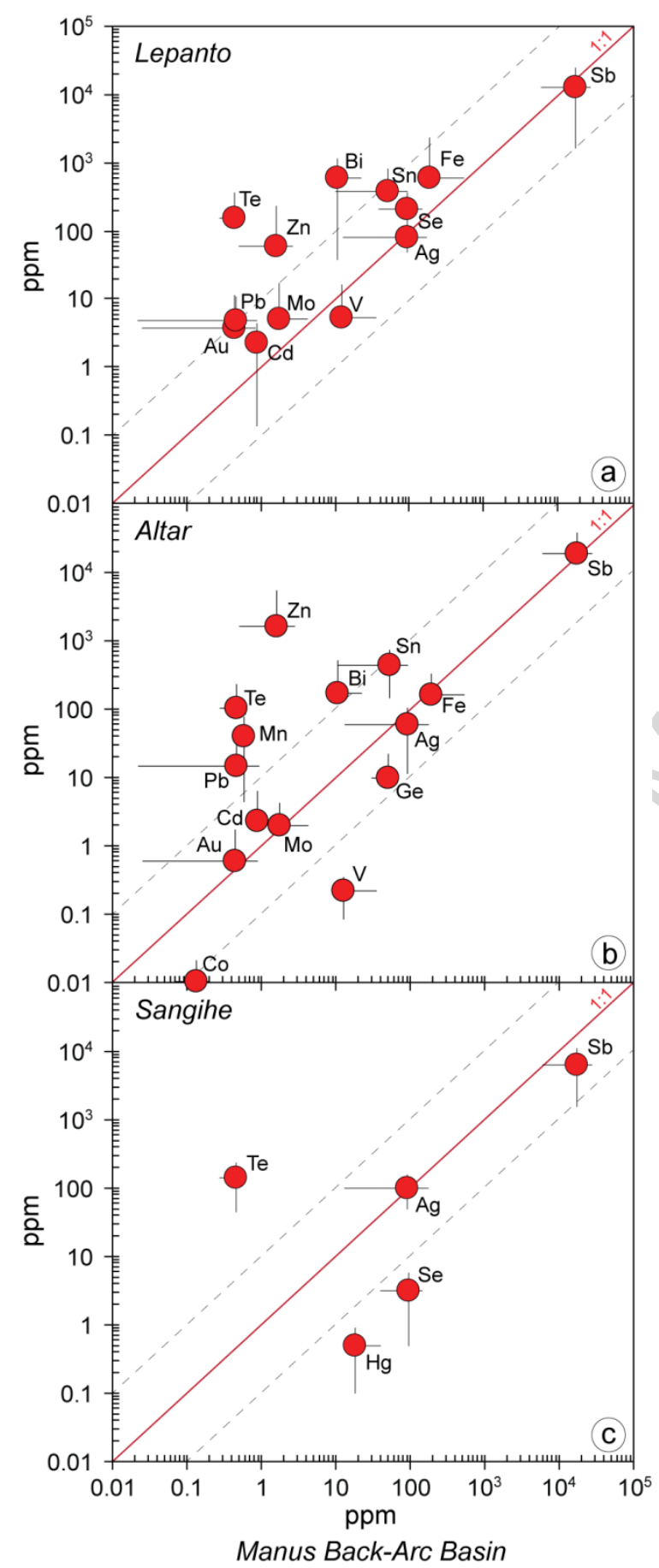

Fig. 12 

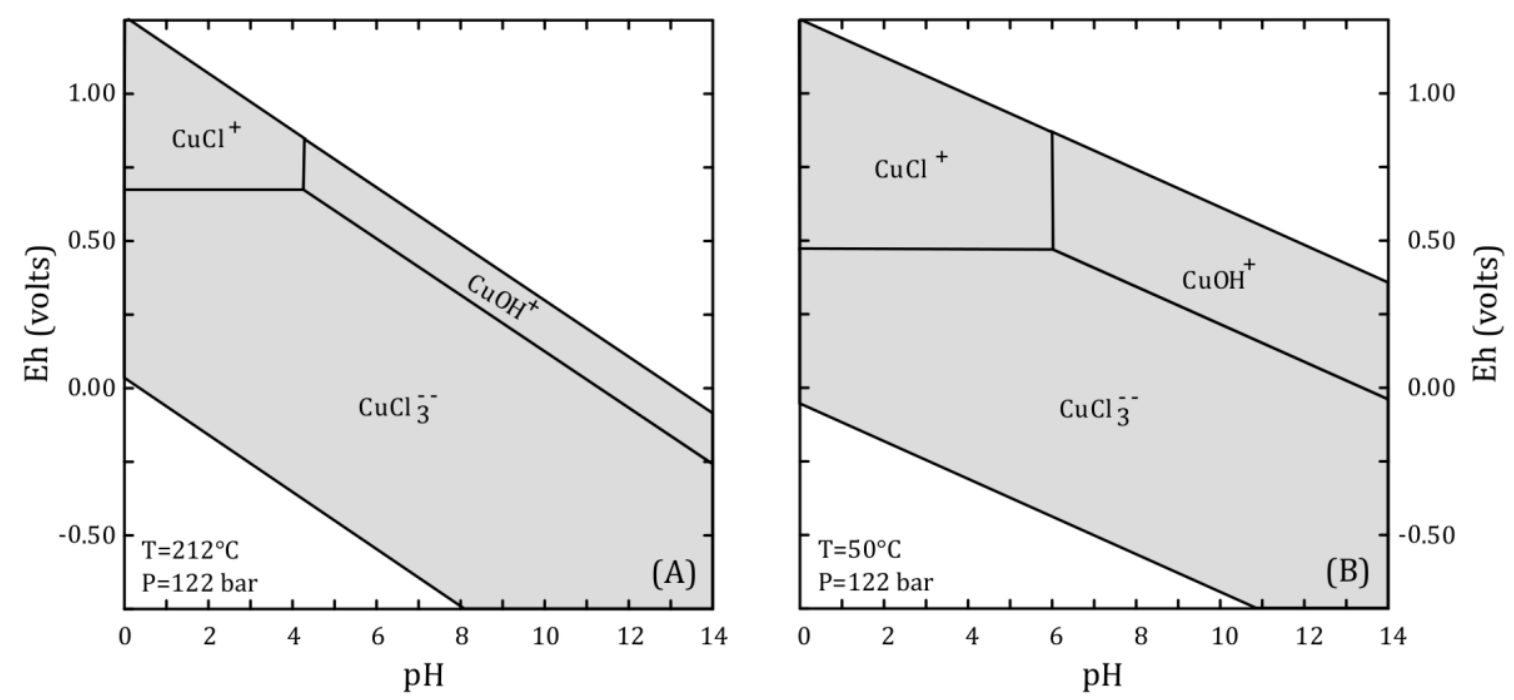

Fig. 13 
Table 1

Investigated enargite-luzonite samples.

\begin{tabular}{|c|c|c|c|c|c|c|c|}
\hline Sample \# & Locality & $\begin{array}{l}\text { Latitude } \\
\text { (S) }\end{array}$ & $\begin{array}{l}\text { Longitude } \\
\text { (E) }\end{array}$ & $\begin{array}{l}\text { Depth } \\
\text { (m) }\end{array}$ & Sampling device & Hand sample description & Mineralogy (XRD) \\
\hline MN 01-12 & $\begin{array}{l}\text { North Su hydrothermal } \\
\text { field, East Manus Basin }\end{array}$ & $03^{\circ} 48.00^{\prime}$ & $152^{\circ} 06.00^{\prime}$ & 1227 & DSV Nautile & $\begin{array}{l}\text { Elongated black (at freshly broken } \\
\text { surface) sulfide slab oxidized at the } \\
\text { surface. }\end{array}$ & $\begin{array}{l}\text { luzonite, enargite, } S^{0} \text {, } \\
\text { marcasite, covellite }\end{array}$ \\
\hline MN 03-11a & $\begin{array}{l}\text { Kaia Natai hydrothermal } \\
\text { field, East Manus Basin }\end{array}$ & $03^{\circ} 49.43^{\prime}$ & $152^{\circ} 11.45^{\prime}$ & 1150 & DSV Nautile & Sulfi & enargite, luzonite \\
\hline $\begin{array}{l}\text { J2-223-13- } \\
\text { R1 }\end{array}$ & $\begin{array}{l}\text { North Su hydrothermal } \\
\text { field, East Manus Basin }\end{array}$ & $03^{\circ} 48.02^{\prime}$ & $152^{\circ} 06.02^{\prime}$ & 1225 & ROV Jason & Active sulfide flange. & $\begin{array}{l}\text { luzonite, enargite, covellite, } \\
\text { tetrahedrite-tennantite, } \\
\text { pyrite, barite, } \mathrm{S}^{0}\end{array}$ \\
\hline
\end{tabular}

Table 2

Unit-cell parameters for studied enargite and luzonite.

\begin{tabular}{|c|c|c|c|c|c|}
\hline Sample \# & Mineral & $\begin{array}{l}a \\
(\AA)\end{array}$ & $\begin{array}{l}b \\
(\AA)\end{array}$ & $\begin{array}{l}c \\
(\AA)\end{array}$ & $\begin{array}{l}V \\
\left(\AA^{3}\right)\end{array}$ \\
\hline MN 01-12 & enargite & $6.434(2)$ & $7.411(3)$ & $6.153(2)$ & $293.4(4)$ \\
\hline MN 01-12 & luzonite & $5.312(1)$ & $5.312(1)$ & $10.530(3)$ & 297.1(2) \\
\hline MN 03-11a & enargite & $6.440(2)$ & $7.406(2)$ & $6.157(2)$ & 293.7(3) \\
\hline MN 03-11a & luzonite & $5.318(2)$ & $5.318(2)$ & $10.541(5)$ & 298.1(5) \\
\hline J2-223-13-R1 & enargite & $6.437(1)$ & $7.408(1)$ & $6.155(1)$ & $293.5(1)$ \\
\hline J2-223-13-R1 & luzonite & $5.314(1)$ & $5.314(1)$ & $10.534(2)$ & $297.5(1)$ \\
\hline
\end{tabular}

Table 3

Chemical composition (average of selected EMP data) and structural formulae of enargite and luzonite from seafloor hydrothermal fields.

$$
\text { Structural formulae }
$$

Location/Sampmineral $\mathrm{Cu} \quad \mathrm{As} \quad \mathrm{S} \quad \mathrm{Sb} \quad \mathrm{Hg} \quad \mathrm{Fe} \quad \mathrm{Zn} \quad \mathrm{Ag} \quad \mathrm{Se} \quad \mathrm{Pb} \quad \mathrm{Mn} \quad \mathrm{Cd}$ Total Cu As S Sb $\mathrm{Hg}$ Fe Zn Ag Se Pb Mn Cd Tota le \# (wt.\%(wt.\%(wt.\%(wt.\%(wt.\%(wt.\%(wt.\%(wt.\%(wt.\%(wt.\%(wt.\%(wt.\%(wt.\%

\begin{tabular}{|c|c|c|c|c|c|c|c|c|c|c|}
\hline \multirow{2}{*}{\multicolumn{11}{|c|}{$\begin{array}{l}\text { Manus Back- } \\
\text { Arc Basin }\end{array}$}} \\
\hline & & & & & & & & & & \\
\hline MN 01-12 & luzonit & 48.2018 .3032 .43 & 0.70 & 0.24 & $<0.07<0.16$ & n.a. ${ }^{2}$ & n.a. & n.a. & n.a. & n.a. $99.913 .00 .94 .00 .00 .00 .00 .0 \mathrm{n}$ \\
\hline crystal $(10)^{1}$ & & & & & & & & & & $\begin{array}{lllllll}0 & 7 & 0 & 2 & 0 & 0 & 0\end{array}$ \\
\hline $\begin{array}{l}\text { MN 01-12 } \\
\text { crystal }(3)^{1}\end{array}$ & $\begin{array}{r}\text { enargit } \\
\mathrm{e}\end{array}$ & 48.1018 .0032 .50 & 0.80 & 0.30 & $0.08<0.16$ & n.a. & n.a. & n.a. & n.a. & $\begin{array}{cccccccccc}\text { n.a. } 99.78 & 3.0 & 0.9 & 4.0 & 0.0 & 0.0 & 0.0 & 0.0 & \text { n.a.n.a.n.a.n.a.n.a. } 8.00-\text { " - } \\
0 & 6 & 1 & 2 & 0 & 0 & 0\end{array}$ \\
\hline $\begin{array}{l}\text { MN 01-12 } \\
\text { colloform (4) }\end{array}$ & $\begin{array}{r}\text { luzonit } \\
\mathrm{e}\end{array}$ & 47.0217 .9432 .16 & 0.70 & $<0.10$ & $0.46<0.16$ & n.a. & n.a. & n.a. & n.a. & $\begin{array}{cccccccccc}\text { n.a. } 98.27 & 2.9 & 0.9 & 4.0 & 0.0 & 0.0 & 0.0 & 0.0 \text { n.a.n.a.n.a.n.a.n.a. } 8.00-\text { “ } \\
7 & 6 & 2 & 2 & 0 & 3 & 0\end{array}$ \\
\hline $\begin{array}{l}\text { MN 03-11a } \\
(8)^{1}\end{array}$ & $\begin{array}{r}\text { enargit } \\
\mathrm{e}\end{array}$ & 48.6716 .6132 .44 & 2.94 & 0.29 & $<0.07<0.16$ & n.a. & n.a. & n.a. & n.a. & $\begin{array}{cccccccccc}\text { n.a. } 100.9 & 3.0 & 0.8 & 4.0 & 0.1 & 0.0 & 0.0 & 0.0 & \text { n.a.n.a.n.a.n.a.n.a. } 8.00- \\
7 & 3 & 8 & 0 & 0 & 1 & 0 & 0\end{array}$ \\
\hline $\begin{array}{l}\text { J2-223-13-R1 } \\
(7)^{1}\end{array}$ & $\begin{array}{r}\text { luzonit } \\
\mathrm{e}\end{array}$ & 49.6017 .7833 .13 & 0.78 & 0.16 & $0.17<0.16$ & n.a. & n.a. & n.a. & n.a. & $\begin{array}{cccccccccc}\text { n.a. } 101.6 & 3.0 & 0.9 & 4.0 & 0.0 & 0.0 & 0.0 & 0.0 \text { n.a.n.a. n.a.n.a.n.a. } 8.00-\text { " - } \\
4 & 3 & 2 & 1 & 2 & 0 & 1 & 0\end{array}$ \\
\hline
\end{tabular}

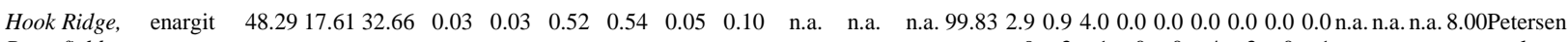
Bransfield e $\quad$ Stait

Strait (10) 1

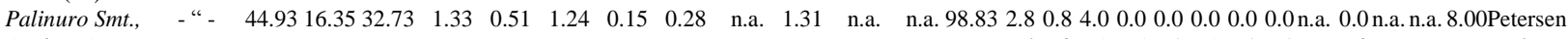

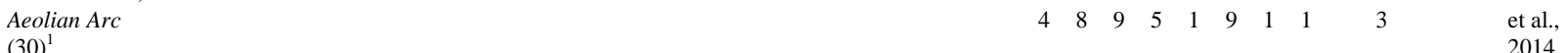

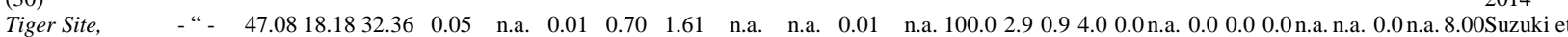

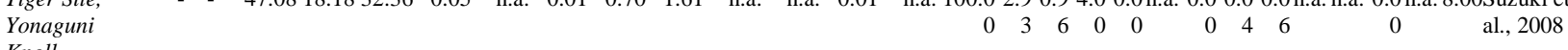

Knoll,

Okinawa

Trough (12)

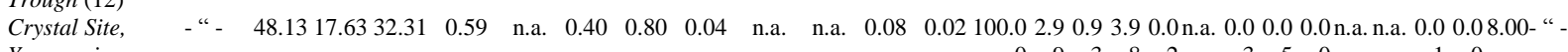

Yonaguni

Knoll,

Okinawa

Trough (13)

Triades, Milos - " - $41.0914 .0529 .85 \quad 5.34$ n.a. $0.25 \quad 1.60 \quad 7.13 \quad$ n.a. n.a. n.a. n.a. 99.312 .7 0.7 3.9 0.1 n.a. 0.0 0.1 0.2 n.a.n.a.n.a.n.a.8.00Alfieris

Island, Aegean
Arc 


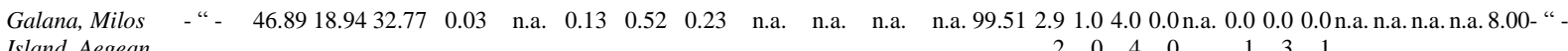

Island, Aegean $\quad \begin{array}{ccccccc} & 0 & 4 & 0 & 1 & 3 & 1\end{array}$

$\operatorname{Arc}$

${ }^{1}$ Number of point analyses.

${ }^{2}$ n.a. $=$ not analyzed.

Table 4

Bulk chemical composition (XRF and ICP-MS), $\delta^{34} \mathrm{~S}$ and $\delta^{65} \mathrm{Cu}(\mathrm{MC}-\mathrm{ICP}-\mathrm{MS}$ ) of investigated enargite-luzonite samples.

\begin{tabular}{|c|c|c|c|c|c|c|}
\hline $\begin{array}{l}\text { Sample } \\
\text { Method } \\
\text { Element }\end{array}$ & MN 01-12 & MN 03-11a & $\mathrm{J} 2-223-13-\mathrm{R} 1 \mathrm{a}$ & $\mathrm{J} 2-223-13-\mathrm{R}$ & $\begin{array}{l}\text { Volcanic rocks, } \\
\text { East Manus Basin }\end{array}$ & $\begin{array}{l}\text { MORB, } \\
\text { global range }^{2}\end{array}$ \\
\hline \multicolumn{7}{|l|}{$X R F$} \\
\hline $\mathrm{SiO}_{2}$, wt. $\%$ & 4.70 & 0.4 & $<0.5$ & $<0.5$ & $46.4-71.5$ & $50.2-51.0$ \\
\hline $\mathrm{Al}_{2} \mathrm{O}_{3}$ & $<0.3$ & $<0.3$ & $<1$ & $<1$ & $10.4-17.4$ & $14.8-16.1$ \\
\hline $\mathrm{TiO}_{2}$ & 0.03 & 0.05 & $<0.2$ & 0.05 & $0.35-2.41$ & $0.82-1.72$ \\
\hline $\mathrm{MgO}$ & $<0.3$ & $<0.3$ & $<0.3$ & $<0.3$ & $0.38-17.2$ & $7.23-8.53$ \\
\hline $\mathrm{K}_{2} \mathrm{O}$ & $<0.02$ & $<0.02$ & $<0.02$ & $<0.02$ & $0.01-2.28$ & $0.05-0.24$ \\
\hline $\mathrm{P}_{2} \mathrm{O}_{5}$ & $<0.02$ & 0.04 & 0.02 & 0.02 & $0.03-0.55$ & $0.06-0.22$ \\
\hline $\mathrm{S}_{\text {total }} 3$ & 37.0 & 29.2 & 32.1 & 46.5 & $<0.01-0.30$ & 0.11 \\
\hline $\mathrm{Ba}^{3}$ & 4.93 & 9.32 & 3.63 & 17.7 & $<0.0002-0.0305$ & $0.0012-0.0022$ \\
\hline & \multicolumn{4}{|c|}{$I C P-M S$} & $<0.1-0.2$ & 0.03 \\
\hline $\mathrm{S}_{\mathrm{total}}, \mathrm{wt} . \%$ & 23.0 & 18.9 & 20.8 & 30.0 & & \\
\hline $\mathrm{Ba}$ & 0.005 & 0.002 & 0.005 & 0.010 & $0.0147-0.0400$ & \\
\hline $\mathrm{Ca}$ & 0.01 & 0.07 & 0.06 & 0.10 & $1.34-9.70$ & $7.39-9.29$ \\
\hline As & 11.1 & 17.8 & 18.5 & 3.60 & 0.00013-0.00045 & 0.000011 \\
\hline $\mathrm{Cu}$ & 27.5 & 39.2 & 41.5 & 12.6 & $0.0008-0.0507$ & $0.0082-0.0137$ \\
\hline $\mathrm{Fe}$ & 4.43 & 1.20 & 0.94 & 11.6 & $2.69-13.6$ & $6.80-8.15$ \\
\hline $\mathrm{Sb}$ & 0.32 & 1.96 & 0.97 & 0.05 & $0.000003-0.000014$ & 0.000001 \\
\hline $\mathrm{Au}, \mathrm{ppm}$ & 16.7 & 1.89 & 2.22 & 27.0 & $<0.001-0.015$ & $0.0005-0.001$ \\
\hline $\mathrm{Bi}$ & 262 & 38.3 & 155 & 15.4 & $<0.5$ & 0.010 \\
\hline $\mathrm{Cd}$ & 2.11 & 0.10 & 0.04 & 0.35 & $<0.2-0.8$ & 0.14 \\
\hline $\mathrm{Co}$ & 0.27 & 0.54 & 0.26 & 0.42 & $5-59$ & $37.8-54.0$ \\
\hline $\mathrm{Cr}$ & 0.09 & 0.71 & $<0.18$ & 0.89 & $1-370$ & $161-253$ \\
\hline In & 0.70 & 0.25 & 1.85 & 0.40 & $0.04-0.08$ & 0.075 \\
\hline $\mathrm{Mn}$ & 2.46 & 11.1 & $<1.06$ & 3.40 & $852-2865$ & $1239-1394$ \\
\hline Mo & 3.60 & 18.8 & 4.04 & 20.8 & & $0.31-0.47$ \\
\hline $\mathrm{Ni}$ & 0.16 & 0.54 & 0.53 & 3.17 & $<1-246$ & $81-123$ \\
\hline $\mathrm{Pb}$ & 1221 & 4.3 & 54.0 & 220 & $<1-24$ & $0.2-0.4$ \\
\hline $\mathrm{Se}$ & 35.2 & 51.6 & 59.4 & 24.9 & $0.119-0.355$ & 0.21 \\
\hline $\mathrm{Sn}$ & 133 & 62.4 & 505 & 33.7 & $0.30-1.20$ & 1 \\
\hline $\mathrm{Te}$ & 46.5 & 0.82 & 602 & 28.0 & & 0.0049 \\
\hline $\mathrm{Tl}$ & 11.4 & $<0.91$ & $<0.91$ & 8.56 & $0.04-0.26$ & $0.0014-0.013$ \\
\hline $\mathrm{U}$ & 0.05 & 1.42 & 0.05 & 0.05 & $0.34-2$ & 0.06 \\
\hline $\mathrm{V}$ & 31.1 & 25.0 & 39.3 & 71.2 & $6-454$ & $220-265$ \\
\hline $\mathrm{Zn}$ & 42.7 & 47.8 & 69.1 & 65.1 & $50-506$ & 80 \\
\hline \multicolumn{7}{|l|}{$M C-I C P-M S$} \\
\hline$\delta^{34} \mathrm{~S} \pm 2 \sigma, \%$ & $-4.10 \pm 0.25$ & $-8.58 \pm 0.25$ & $-4.85 \pm 0.25$ & $-3.72 \pm 0.25$ & $0.3-1.9^{5}$ & $-0.91 \pm 0.50^{6}$ \\
\hline$\delta^{65} \mathrm{Cu} \pm 2 \sigma, \%$ & $0.35 \pm 0.03$ & $0.02 \pm 0.03$ & $-0.19 \pm 0.02$ & $0.10 \pm 0.02$ & - & $0^{7}$ \\
\hline
\end{tabular}

${ }^{1}$ Compositional range of basalts, basaltic andesites, andesites and dacites: Moss et al. (2001), Sinton et al. (2003), Monecke et al. (2007), Jenner et al. (2010), Park et al. (2010).

${ }^{2}$ Klein (2003), Arevalo and McDonough (2010).

${ }^{3} \mathrm{~S}_{\text {total }}$ and Ba concentrations measured by XRF and ICP-MS methods differ due to incomplete digestion of barite for ICP-MS measurements. 
${ }^{4}$ n.d. $=$ not determined.

${ }^{5}$ Data for Mariana Trough basalts, basaltic andesites and andesites: Alt et al. (1993).

${ }^{6}$ Labidi et al. (2012).

${ }^{7}$ Ben Othman et al. (2006).

Table 5

Average bulk chemical compositions (selected metals and metalloids) of investigated enargite-luzonite and other seafloor hydrothermal sulfide deposits.

\begin{tabular}{|c|c|c|c|c|c|c|c|c|c|}
\hline \multirow{2}{*}{$\begin{array}{c}\text { Setting } \\
\text { Deposits } \\
\text { Element }\end{array}$} & \multirow{2}{*}{$\begin{array}{l}\text { BAB } \\
\text { enargite- } \\
\text { luzonite }\end{array}$} & \multirow[b]{2}{*}{$\begin{array}{l}\text { East } \\
\text { Manus } 1\end{array}$} & \multirow[b]{2}{*}{$\begin{array}{l}\text { North } \\
\text { Fiji }^{2}\end{array}$} & \multirow[b]{2}{*}{$\mathrm{Lau}^{3}$} & \multirow[b]{2}{*}{ Okinawa $^{4}$} & \multirow[b]{2}{*}{ Mariana $^{5}$} & \multicolumn{2}{|c|}{ MOR, unsedimented } & \multirow[b]{2}{*}{$\begin{array}{l}\text { East Pacific } \\
\text { Rise, mafic- } \\
\text { hosted }^{7}\end{array}$} \\
\hline & & & & & & & $\begin{array}{l}\text { Mid-Atlantic } \\
\text { Ridge, mafic- } \\
\text { hosted }^{6}\end{array}$ & $\begin{array}{l}\text { Mid-Atlantic } \\
\text { Ridge, } \\
\text { ultramafic- } \\
\text { hosted }^{6}\end{array}$ & \\
\hline $\mathrm{Cu}$, wt. $\%$ & 30.2 & 7.25 & 7.45 & 4.6 & 1.77 & 1.15 & 6.67 & 15.9 & 9.50 \\
\hline $\mathrm{Zn}$ & 0.01 & 13.6 & 6.64 & 16.1 & 22.0 & 9.96 & 4.65 & 10.8 & 6.33 \\
\hline $\mathrm{Pb}$ & 0.04 & 1.93 & 0.06 & 0.33 & 14.3 & 7.40 & 0.03 & 0.27 & 0.04 \\
\hline As & 12.7 & 0.61 & 0.02 & 0.22 & 2.75 & 0.01 & 0.02 & 0.02 & 0.02 \\
\hline $\mathrm{Sb}$ & 0.83 & 0.05 & 0.003 & 0.01 & - & 0.02 & 0.004 & 0.003 & 0.001 \\
\hline Se, ppm & 43 & 22 & 168 & 8 & - & 10 & 103 & 445 & - \\
\hline $\mathrm{Bi}$ & 117 & 11 & - & - & & - & 3 & 13 & - \\
\hline $\mathrm{Te}$ & 169 & 12 & - & - & - & - & 1 & - & - \\
\hline Мo & 12 & 93 & 269 & 32 & - & 5 & 69 & 65 & 132 \\
\hline $\mathrm{Tl}$ & 10 & - & - & - & - & - & 15 & - & - \\
\hline $\mathrm{Cd}$ & 1 & 508 & 260 & 482 & 950 & 465 & 169 & 230 & 259 \\
\hline $\mathrm{Mn}$ & 6 & - & 761 & 542 & 1567 & 175 & 466 & 768 & 212 \\
\hline $\mathrm{Ni}$ & 1 & - & $<20$ & 6 & 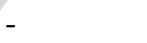 & - & 33 & 231 & - \\
\hline Co & 1 & 28 & 238 & 3 & - & 2 & 235 & 1192 & 741 \\
\hline $\mathrm{Sn}$ & 184 & - & $<10$ & 4 & - & - & 12 & 378 & 266 \\
\hline $\mathrm{Ag}$ & 128 & 313 & 151 & 256 & 2100 & 184 & 60 & 80 & 51 \\
\hline $\mathrm{Au}$ & 11.9 & 8.9 & & 1.4 & 4.6 & 0.8 & 1.6 & 11.2 & 0.5 \\
\hline In & 1 & - & & - & - & - & 5 & 10 & - \\
\hline $\mathrm{U}$ & 1 & - & - & - & - & - & 6 & 16 & - \\
\hline
\end{tabular}

${ }^{1}$ Moss and Scott (2001).

${ }^{2}$ Bendel (1993), Bendel et al. (1993).

${ }^{3}$ Fouquet et al. (1993a).

${ }^{4}$ Halbach et al. (1989).

${ }^{5}$ Hannington et al. (1990).

${ }^{6}$ Fouquet et al. (2010).

${ }^{7}$ Krasnov et al. (1995). 
Table 6

$\delta^{65} \mathrm{Cu}(\mathrm{MC}-\mathrm{ICP}-\mathrm{MS})$ of the active enargite-luzonite flange (J2-223-13-R1).

\begin{tabular}{lrl}
\hline Spot $\#^{1}$ & \multicolumn{1}{l}{$\begin{array}{l}\delta^{65} \mathrm{Cu} \\
(\%)\end{array}$} & $\begin{array}{l}2 \sigma \\
(\%)\end{array}$ \\
\hline 2 & -0.07 & 0.11 \\
3 & -0.11 & 0.11 \\
4 & -0.18 & 0.06 \\
5 & -0.07 & 0.04 \\
6 & -0.20 & 0.02 \\
7 & 0.13 & 0.09 \\
8 & -0.15 & 0.00 \\
9 & -0.19 & 0.10 \\
10 & -0.09 & 0.01 \\
11 & -0.05 & 0.03 \\
12 & 0.00 & 0.02 \\
13 & -0.04 & 0.03 \\
14 & 0.01 & 0.09 \\
\hline
\end{tabular}

${ }^{1}$ See spot locations at Figure 11.

\section{Appendix 1}

LA-ICP-MS instrument and data acquisition parameters.

Excimer $193 \mathrm{~nm}$ ArF laser Compex $110 \mathrm{I}$

Output energy

Homogeneous energy density on sample

Repetition rate

Ablation mode

Ablation crater size

Ablation cell

\section{Enargite, Luzonite, Pyrite/Marcasite}

$30 \mathrm{~mJ}$

$\sim 5 \mathrm{~J} / \mathrm{cm}^{2}$

$5 \mathrm{~Hz}$

single hole

50-60 $\mu \mathrm{m}$

in-house built glass chamber with anti-reflection

coated silica glass window

$1550 \mathrm{~W}$

dual

$3 \mathrm{~ms}$

$0.801 / \mathrm{min} \mathrm{Ar}$

$0.85 \mathrm{l} / \mathrm{min} \mathrm{Ar}$

15.5 1/min Ar

$1.1 \mathrm{l} / \mathrm{min} \mathrm{He}$

$5 \mathrm{ml} / \mathrm{min} \mathrm{H}_{2}$

1

140

1

$10 \mathrm{~ms}$ for all elements

1 per measurement 
Oxide production rate

Isotopes analyzed tuned to $<0.5 \% \mathrm{ThO}$

${ }^{32} \mathrm{~S},{ }^{51} \mathrm{~V},{ }^{55} \mathrm{Mn},{ }^{57} \mathrm{Fe},{ }^{59} \mathrm{Co},{ }^{60} \mathrm{Ni},{ }^{65} \mathrm{Cu},{ }^{66} \mathrm{Zn},{ }^{69} \mathrm{Ga}$,

${ }^{74} \mathrm{Ge},{ }^{75} \mathrm{As},{ }^{77} \mathrm{Se},{ }^{95} \mathrm{Mo},{ }^{107} \mathrm{Ag},{ }^{111} \mathrm{Cd},{ }^{113} \mathrm{In},{ }^{118} \mathrm{Sn}$,

${ }^{121} \mathrm{Sb},{ }^{125} \mathrm{Te},{ }^{182} \mathrm{~W},{ }^{197} \mathrm{Au},{ }^{202} \mathrm{Hg},{ }^{205} \mathrm{Tl},{ }^{208} \mathrm{~Pb},{ }^{209} \mathrm{Bi}$

Appendix 2

Electron microprobe analyses (wt\%) of enargite and luzonite from the Manus Back-Arc Basin.

\begin{tabular}{|c|c|c|c|c|c|c|c|c|c|c|}
\hline Sample \# & Mineral & $\mathrm{S}$ & $\mathrm{Fe}$ & $\mathrm{Cu}$ & As & $\mathrm{Se}$ & $\mathrm{Sn}$ & $\mathrm{Sb}$ & $\mathrm{Te}$ & Total \\
\hline \multirow[t]{30}{*}{ J2-223-13-R1 } & \multirow[t]{30}{*}{ luzonite } & 32.22 & 0.65 & 47.10 & 16.91 & n.d. & 0.11 & 1.17 & 0.06 & 98.22 \\
\hline & & 32.05 & 0.80 & 47.76 & 16.68 & 0.11 & 0.13 & 1.55 & 0.09 & 99.16 \\
\hline & & 32.01 & 0.93 & 47.43 & 16.07 & n.d. & 0.15 & 1.82 & 0.16 & 98.57 \\
\hline & & 32.24 & 0.95 & 47.50 & 16.51 & n.d. & 0.11 & 1.34 & 0.08 & 98.73 \\
\hline & & 32.15 & 0.87 & 47.45 & 17.01 & n.d. & 0.11 & 0.86 & 0.05 & 98.50 \\
\hline & & 32.21 & 0.89 & 47.57 & 16.40 & n.d. & 0.12 & 1.55 & 0.12 & 98.87 \\
\hline & & 31.80 & 0.71 & 47.48 & 16.80 & n.d. & 0.14 & 1.49 & 0.13 & 98.54 \\
\hline & & 32.27 & 0.50 & 47.77 & 16.57 & n.d. & 0.13 & 1.62 & 0.13 & 98.98 \\
\hline & & 32.22 & 0.65 & 47.64 & 16.96 & n.d. & 0.11 & 0.75 & 0.03 & 98.36 \\
\hline & & 32.11 & 0.76 & 48.02 & 16.50 & 0.10 & 0.13 & 1.60 & 0.13 & 99.35 \\
\hline & & 32.11 & 0.90 & 47.19 & 16.00 & 0.10 & 0.15 & 2.02 & 0.18 & 98.64 \\
\hline & & 31.78 & 1.16 & 47.70 & 15.86 & n.d. & 0.15 & 1.81 & 0.15 & 98.62 \\
\hline & & 31.88 & 1.10 & 47.50 & 16.37 & n.d. & 0.12 & 1.36 & 0.10 & 98.43 \\
\hline & & 32.22 & 0.98 & 47.97 & 16.62 & n.d. & 0.12 & 1.02 & 0.08 & 99.01 \\
\hline & & 32.05 & 0.92 & 47.25 & 16.56 & 0.10 & 0.10 & 1.36 & 0.13 & 98.48 \\
\hline & & 32.06 & 0.79 & 48.00 & 17.25 & n.d. & 0.07 & 0.59 & & 98.76 \\
\hline & & 32.10 & 0.87 & 47.44 & 16.83 & n.d. & 0.10 & 0.88 & 0.04 & 98.25 \\
\hline & & 32.22 & 0.42 & 47.43 & 16.69 & n.d. & 0.13 & 1.50 & 0.15 & 98.55 \\
\hline & & 31.91 & 0.82 & 47.52 & 17.11 & n.d. & 0.10 & 0.81 & 0.07 & 98.33 \\
\hline & & 31.96 & 0.82 & 47.35 & 16.62 & n.d. & 0.10 & 1.13 & 0.07 & 98.04 \\
\hline & & 32.20 & 0.58 & 47.21 & 16.99 & n.d. & 0.10 & 0.90 & 0.04 & 98.03 \\
\hline & & 32.21 & 0.56 & 47.50 & 16.67 & n.d. & 0.13 & 1.55 & 0.13 & 98.74 \\
\hline & & 32.30 & 0.55 & 47.45 & 16.70 & n.d. & 0.11 & 1.32 & 0.10 & 98.53 \\
\hline & & 33.10 & 0.12 & 49.63 & 17.71 & n.a. & n.a. & 0.95 & n.a. & 101.52 \\
\hline & & 33.33 & 0.14 & 49.63 & 18.12 & n.a. & n.a. & 0.80 & n.a. & 102.02 \\
\hline & & 32.91 & n.d. & 49.98 & 17.35 & n.a. & n.a. & 1.11 & n.a. & 101.35 \\
\hline & & 33.12 & 0.21 & 49.39 & 17.96 & n.a. & n.a. & 0.55 & n.a. & 101.23 \\
\hline & & 33.10 & 0.14 & 49.19 & 17.89 & n.a. & n.a. & 0.81 & n.a. & 101.13 \\
\hline & & 33.49 & 0.26 & 49.86 & 17.82 & n.a. & n.a. & 0.61 & n.a. & 102.03 \\
\hline & & 32.90 & 0.30 & 49.51 & 17.59 & n.a. & n.a. & 0.64 & n.a. & 100.94 \\
\hline Geometric & \multirow{4}{*}{ mean } & 32.34 & 0.50 & 48.01 & 16.89 & 0.10 & 0.12 & 1.11 & 0.09 & 99.26 \\
\hline STD & & 0.47 & 0.32 & 0.92 & 0.59 & 0.00 & 0.02 & 0.41 & 0.04 & 1.28 \\
\hline$L O D$ & & 0.04 & 0.03 & 0.04 & 0.10 & 0.03 & 0.03 & 0.03 & 0.03 & \\
\hline$n$ & & 29 & 29 & 29 & 29 & 29 & 29 & 29 & 29 & 29 \\
\hline \multirow[t]{12}{*}{ MN 01-12 } & \multirow[t]{12}{*}{ luzonite } & 32.68 & 0.60 & 46.91 & 17.43 & n.d. & 0.06 & 0.80 & n.d. & 98.49 \\
\hline & & 32.78 & 1.16 & 47.22 & 17.48 & n.d. & 0.06 & 0.22 & n.d. & 98.91 \\
\hline & & 32.62 & 1.80 & 47.43 & 16.55 & n.d. & 0.06 & 0.29 & n.d. & 98.74 \\
\hline & & 32.30 & 0.97 & 47.28 & 16.98 & n.d. & 0.07 & 0.65 & 0.03 & 98.27 \\
\hline & & 32.47 & 0.68 & 47.47 & 16.70 & 0.12 & 0.06 & 0.89 & 0.03 & 98.42 \\
\hline & & 32.50 & n.d. & 47.47 & 17.98 & n.d. & 0.08 & 0.87 & 0.03 & 98.94 \\
\hline & & 32.24 & 0.08 & 47.67 & 17.90 & n.d. & 0.05 & 0.78 & n.d. & 98.72 \\
\hline & & 32.42 & 2.74 & 46.91 & 16.89 & 0.10 & 0.03 & 0.24 & n.d. & 99.33 \\
\hline & & 32.73 & n.d. & 46.91 & 18.20 & n.d. & 0.06 & 0.59 & 0.04 & 98.53 \\
\hline & & 32.21 & n.d. & 46.57 & 18.45 & 0.10 & 0.06 & 0.63 & n.d. & 98.02 \\
\hline & & 32.57 & n.d. & 46.97 & 18.22 & n.d. & 0.06 & 0.65 & n.d. & 98.47 \\
\hline & & 32.28 & n.d. & 46.82 & 17.53 & 0.10 & 0.11 & 1.16 & 0.03 & 98.04 \\
\hline
\end{tabular}




\begin{tabular}{|c|c|c|c|c|c|c|c|c|c|c|}
\hline & & 32.37 & n.d. & 46.90 & 18.11 & n.d. & 0.06 & 0.61 & 0.05 & 98.11 \\
\hline & & 32.45 & n.d. & 46.87 & 18.24 & n.d. & 0.05 & 0.57 & 0.05 & 98.24 \\
\hline & & 32.37 & n.d. & 47.18 & 18.16 & n.d. & 0.07 & 0.57 & 0.04 & 98.39 \\
\hline & & 32.36 & n.d. & 47.10 & 17.93 & n.d. & 0.09 & 0.84 & n.d. & 98.31 \\
\hline & & 32.25 & 0.04 & 47.53 & 17.74 & n.d. & 0.09 & 0.89 & 0.05 & 98.59 \\
\hline & & 32.15 & 0.06 & 47.42 & 17.96 & n.d. & 0.09 & 0.92 & 0.04 & 98.64 \\
\hline & & 32.32 & n.d. & 47.21 & 18.08 & n.d. & 0.07 & 1.01 & 0.04 & 98.74 \\
\hline & & 32.16 & 0.05 & 47.17 & 17.54 & n.d. & 0.07 & 1.15 & 0.04 & 98.18 \\
\hline & & 32.15 & n.d. & 47.74 & 18.13 & n.d. & 0.07 & 0.87 & n.d. & 98.96 \\
\hline & & 32.49 & n.d. & 47.28 & 18.15 & n.d. & 0.07 & 0.77 & n.d. & 98.75 \\
\hline & & 32.11 & n.d. & 47.97 & 17.78 & n.d. & 0.10 & 1.25 & 0.06 & 99.26 \\
\hline & & 32.00 & n.d. & 47.47 & 17.58 & n.d. & 0.11 & 1.28 & 0.05 & 98.49 \\
\hline & & 32.11 & n.d. & 48.27 & 18.07 & n.d. & 0.07 & 0.98 & n.d. & 99.49 \\
\hline & & 32.17 & n.d. & 47.75 & 17.81 & n.d. & 0.09 & 1.20 & n.d. & 99.03 \\
\hline & & 32.09 & n.d. & 48.34 & 17.83 & 0.12 & 0.05 & 1.00 & 0.04 & 99.46 \\
\hline & & 32.35 & n.d. & 47.95 & 17.56 & 0.12 & 0.07 & 1.02 & 0.05 & 99.11 \\
\hline & & 32.04 & n.d. & 48.37 & 17.90 & n.d. & 0.05 & 0.97 & n.d. & 99.33 \\
\hline & & 32.38 & 0.06 & 47.83 & 17.62 & n.d. & 0.09 & 1.22 & 0.05 & 99.26 \\
\hline & & 32.05 & n.d. & 48.55 & 17.91 & n.d. & 0.07 & 1.05 & 0.03 & 99.65 \\
\hline & & 32.00 & n.d. & 47.85 & 17.86 & n.d. & 0.06 & 0.96 & n.d. & 98.73 \\
\hline & & 32.04 & n.d. & 48.35 & 18.00 & n.d. & 0.05 & 0.92 & 0.04 & 99.40 \\
\hline & & 32.77 & n.d. & 49.11 & 18.51 & n.a. & n.a. & 0.73 & n.a. & 101.12 \\
\hline & & 33.12 & 0.03 & 49.21 & 18.40 & n.a. & n.a. & 0.55 & n.a. & 101.30 \\
\hline & & 32.28 & 0.04 & 49.15 & 18.38 & n.a. & n.a. & 0.84 & n.a. & 100.69 \\
\hline & & 32.43 & n.d. & 49.39 & 18.52 & n.a. & n.a. & 0.64 & n.a. & 100.99 \\
\hline & & 33.18 & n.d. & 48.96 & 18.23 & n.a. & n.a. & 0.51 & n.a. & 100.90 \\
\hline & & 32.75 & 0.10 & 49.26 & 18.21 & n.a. & n.a. & 0.67 & n.a. & 101.00 \\
\hline & & 32.52 & 0.02 & 48.90 & 18.23 & n.a. & n.a. & 0.67 & n.a. & 100.36 \\
\hline & & 32.16 & 0.11 & 47.36 & 17.85 & n.a. & n.a. & 0.72 & n.a. & 98.21 \\
\hline & & 32.10 & 0.05 & 47.17 & 18.17 & n.a. & n.a. & 0.86 & n.a. & 98.35 \\
\hline & & 32.26 & 0.03 & 46.97 & 18.32 & n.a. & n.a. & 0.67 & n.a. & 98.25 \\
\hline & & 31.64 & 0.08 & 47.14 & 18.32 & n.a. & n.a. & 1.11 & n.a. & 98.30 \\
\hline & & 32.23 & 0.03 & 47.10 & 18.13 & n.a. & n.a. & 0.68 & n.a. & 98.17 \\
\hline & & 32.09 & 0.05 & 46.85 & 18.66 & n.a. & n.a. & 0.50 & n.a. & 98.15 \\
\hline & & 32.17 & 0.13 & 47.04 & 18.24 & n.a. & n.a. & 0.70 & n.a. & 98.28 \\
\hline & & 32.04 & 0.12 & 47.00 & 18.40 & n.a. & n.a. & 0.61 & n.a. & 98.16 \\
\hline & & 32.44 & 0.48 & 47.09 & 17.97 & n.a. & n.a. & 0.63 & n.a. & 98.61 \\
\hline & & 31.99 & 1.10 & 46.96 & 17.13 & n.a. & n.a. & 0.84 & n.a. & 98.02 \\
\hline Geometric & mean & 32.33 & 0.34 & 47.62 & 17.91 & 0.11 & 0.07 & 0.75 & 0.04 & 98.95 \\
\hline$S T D$ & & 0.29 & 0.63 & 0.77 & 0.46 & 0.01 & 0.02 & 0.25 & 0.01 & 0.91 \\
\hline$L O D$ & & 0.04 & 0.03 & 0.04 & 0.10 & 0.03 & 0.03 & 0.03 & 0.03 & \\
\hline$n$ & & 49 & 49 & 49 & 49 & 49 & 49 & 49 & 49 & 49 \\
\hline MN 03-11a & enargite & 32.50 & n.d. & 48.24 & 17.13 & n.d. & 0.06 & 1.88 & 0.05 & 99.87 \\
\hline & & 32.16 & n.d. & 47.38 & 15.62 & n.d. & 0.06 & 4.10 & n.d. & 99.32 \\
\hline & & 32.19 & n.d. & 47.40 & 16.07 & n.d. & 0.06 & 3.24 & n.d. & 98.95 \\
\hline & & 32.00 & n.d. & 47.23 & 15.57 & n.d. & 0.05 & 3.76 & n.d. & 98.60 \\
\hline & & 32.18 & n.d. & 47.88 & 17.32 & n.d. & 0.04 & 1.33 & n.d. & 98.74 \\
\hline & & 31.96 & n.d. & 47.43 & 15.99 & n.d. & 0.06 & 3.39 & n.d. & 98.83 \\
\hline & & 32.49 & n.d. & 47.44 & 16.87 & n.d. & 0.05 & 2.11 & 0.04 & 99.00 \\
\hline & & 32.53 & n.d. & 47.89 & 17.51 & n.d. & 0.05 & 1.41 & n.d. & 99.39 \\
\hline & & 32.66 & n.d. & 47.69 & 17.68 & n.d. & 0.03 & 1.09 & 0.05 & 99.21 \\
\hline & & 32.29 & n.d. & 47.22 & 16.39 & n.d. & 0.06 & 2.94 & 0.03 & 98.92 \\
\hline & & 31.72 & n.d. & 47.55 & 15.86 & 0.13 & 0.06 & 3.66 & n.d. & 98.97 \\
\hline & & 31.69 & n.d. & 48.55 & 14.98 & 0.10 & 0.06 & 3.58 & n.d. & 98.95 \\
\hline & & 32.59 & n.d. & 49.19 & 18.29 & n.d. & n.d. & 0.36 & 0.04 & 100.47 \\
\hline & & 32.59 & n.d. & 48.72 & 18.44 & n.d. & n.d. & 0.13 & n.d. & 99.88 \\
\hline
\end{tabular}




\begin{tabular}{|c|c|c|c|c|c|c|c|c|c|}
\hline & 31.99 & n.d. & 49.15 & 16.43 & n.d. & 0.05 & 3.05 & n.d. & 100.67 \\
\hline & 31.96 & n.d. & 47.88 & 16.48 & n.d. & 0.07 & 2.96 & n.d. & 99.35 \\
\hline & 32.57 & n.d. & 48.16 & 18.14 & 0.10 & 0.05 & 0.48 & n.d. & 99.49 \\
\hline & 32.32 & n.d. & 48.06 & 17.88 & 0.12 & 0.03 & 0.84 & n.d. & 99.24 \\
\hline & 32.52 & n.d. & 48.53 & 18.14 & n.d. & 0.05 & 0.49 & n.d. & 99.72 \\
\hline & 32.51 & n.d. & 48.69 & 18.08 & n.d. & n.d. & 0.46 & n.d. & 99.74 \\
\hline & 32.81 & n.d. & 48.31 & 18.33 & 0.10 & n.d. & 0.41 & n.d. & 99.97 \\
\hline & 32.80 & n.d. & 48.35 & 18.31 & n.d. & 0.05 & 0.24 & 0.03 & 99.78 \\
\hline & 32.76 & n.d. & 48.62 & 18.29 & n.d. & 0.05 & 0.37 & n.d. & 100.08 \\
\hline & 32.60 & n.d. & 48.83 & 18.59 & n.d. & n.d. & 0.22 & n.d. & 100.23 \\
\hline & 32.45 & n.d. & 48.00 & 17.18 & n.d. & 0.05 & 1.78 & 0.03 & 99.50 \\
\hline & 31.94 & n.d. & 47.86 & 16.04 & n.d. & 0.07 & 3.40 & n.d. & 99.32 \\
\hline & 32.46 & n.d. & 47.66 & 16.83 & n.d. & 0.03 & 2.33 & n.d. & 99.31 \\
\hline & 32.47 & n.d. & 48.01 & 17.67 & 0.13 & 0.04 & 1.13 & n.d. & 99.45 \\
\hline & 32.46 & n.d. & 48.03 & 17.58 & n.d. & 0.07 & 1.57 & n.d. & 99.72 \\
\hline & 32.16 & n.d. & 48.15 & 16.22 & 0.10 & 0.07 & 3.40 & 0.03 & 100.12 \\
\hline & 32.17 & n.d. & 47.61 & 16.20 & n.d. & 0.06 & 3.33 & n.d. & 99.37 \\
\hline & 32.42 & n.d. & 47.65 & 17.20 & n.d. & 0.04 & 1.88 & 0.03 & 99.21 \\
\hline & 32.70 & n.d. & 47.33 & 18.23 & n.d. & n.d. & 0.39 & n.d. & 98.65 \\
\hline & 32.64 & n.d. & 47.83 & 18.49 & n.d. & 0.03 & 0.07 & n.d. & 99.07 \\
\hline & 31.60 & n.d. & 47.09 & 14.86 & n.d. & 0.09 & 5.12 & n.d. & 98.76 \\
\hline & 31.49 & n.d. & 47.19 & 15.05 & n.d. & 0.08 & 4.99 & 0.04 & 98.84 \\
\hline & 31.62 & n.d. & 47.21 & 15.19 & n.d. & 0.07 & 5.14 & n.d. & 99.24 \\
\hline & 32.65 & n.d. & 49.09 & 17.73 & n.a. & n.a. & 1.40 & n.a. & 100.88 \\
\hline & 32.33 & 0.04 & 48.81 & 17.06 & n.a. & n.a. & 2.47 & n.a. & 100.71 \\
\hline & 32.17 & n.d. & 48.03 & 15.44 & n.a. & n.a. & 4.52 & n.a. & 100.17 \\
\hline & 32.01 & n.d. & 48.40 & 17.36 & n.a. & n.a. & 1.67 & n.a. & 99.45 \\
\hline & 32.02 & 0.04 & 48.07 & 14.79 & n.a. & n.a. & 5.32 & n.a. & 100.24 \\
\hline & 32.77 & n.d. & 49.16 & 16.66 & n.a. & n.a. & 2.40 & n.a. & 101.00 \\
\hline & 32.76 & n.d. & 48.61 & 16.05 & n.a. & n.a. & 4.11 & n.a. & 101.56 \\
\hline & 32.79 & n.d. & 49.21 & 17.78 & n.a. & n.a. & 1.60 & n.a. & 101.39 \\
\hline Geometric mean & 32.32 & 0.02 & 48.07 & 16.90 & 0.11 & 0.05 & 1.49 & 0.04 & 99.63 \\
\hline$S T D$ & 0.36 & 0.01 & 0.61 & 1.14 & 0.01 & 0.02 & 1.57 & 0.01 & 0.73 \\
\hline$L O D$ & 0.04 & 0.03 & 0.04 & 0.10 & 0.03 & 0.03 & 0.03 & 0.03 & \\
\hline$n$ & 44 & 44 & 44 & 44 & 44 & 44 & 44 & 44 & 44 \\
\hline
\end{tabular}

LOD = limit of detection in wt $\%$; n.d. = not detected $(<\mathrm{LOD}) ;$ n.a. = not analyzed

$\mathrm{Mn}, \mathrm{Zn}$ and $\mathrm{Ag}$ are systematically below the electron microprobe detection limit: $0.12,0.05$, and $0.03 \mathrm{wt} \%$, respectively. 


\section{Appendix 3}

LA-ICP-MS analyses of trace elements in enargite, luzonite and pyrite/marcasite from the Manus Back-Arc Basin.

\begin{tabular}{|c|c|c|c|c|c|c|c|c|c|c|c|c|c|c|c|c|c|c|c|c|c|c|c|}
\hline \multirow[t]{2}{*}{$\#$} & \multicolumn{2}{|c|}{$\begin{array}{l}\text { Sample V } \\
\#\end{array}$} & $\mathrm{Mn}$ & $\mathrm{Fe}$ & Co & $\mathrm{Ni}$ & $\mathrm{Zn}$ & $\mathrm{Ga}$ & $\mathrm{Ge}$ & $\mathrm{Se}$ & Mo & $\mathrm{Ag}$ & $\mathrm{Cd}$ & In & $\mathrm{Sn}$ & $\mathrm{Sb}$ & $\mathrm{Te}$ & W & $\mathrm{Au}$ & $\mathrm{Hg}$ & $\mathrm{Tl}$ & $\mathrm{Pb}$ & $\mathrm{Bi}$ \\
\hline & & $\begin{array}{l}\mu \mathrm{g} / \\
\mathrm{g}\end{array}$ & $\mu \mathrm{g} / \mathrm{g}$ & $\mu \mathrm{g} / \mathrm{g}$ & $\mu \mathrm{g} / \mathrm{g}$ & $\mu \mathrm{g} / \mathrm{g}$ & $\mu \mathrm{g} / \mathrm{g}$ & $\begin{array}{l}\mu \mathrm{g} / \\
\mathrm{g}\end{array}$ & $\begin{array}{l}\mu \mathrm{g} / \\
\mathrm{g}\end{array}$ & $\mu \mathrm{g} / \mathrm{g}$ & $\begin{array}{l}\mu \mathrm{g} / \\
\mathrm{g}\end{array}$ & $\begin{array}{l}\mu \mathrm{g} / \\
\mathrm{g}\end{array}$ & $\mu \mathrm{g} / \mathrm{g}$ & $\mu \mathrm{g} / \mathrm{g}$ & $\mathrm{g}$ & $\mu \mathrm{g} / \mathrm{g}$ & $\mu \mathrm{g} / \mathrm{g}$ & $\mu \mathrm{g} / \mathrm{g}$ & $\begin{array}{l}\mu \mathrm{g} / \\
\mathrm{g}\end{array}$ & $\begin{array}{l}\mu \mathrm{g} / \\
\mathrm{g}\end{array}$ & $\mu \mathrm{g} / \mathrm{g}$ & $\begin{array}{l}\mu \mathrm{g} / \\
\mathrm{g}\end{array}$ & $\begin{array}{l}\mu \mathrm{g} / \\
\mathrm{g}\end{array}$ \\
\hline $1 *$ & $\begin{array}{l}\text { J2-223- } \\
\text { 13-R1 }\end{array}$ & 29 & 1.3 & 6094 & $\begin{array}{r}<0.0 \\
8\end{array}$ & $\begin{array}{r}<0.3 \\
5\end{array}$ & $<1.1$ & 2.7 & 48 & 143 & 1.1 & 15 & 1.6 & 0.82 & 644 & 9725 & 727 & $\begin{array}{r}<0.3 \\
1\end{array}$ & 3.1 & 19 & 0.11 & 8.4 & 222 \\
\hline $2 *$ & $\begin{array}{l}\text { luzonit } \\
\mathrm{e}\end{array}$ & 29 & $\begin{array}{r}<0.5 \\
7\end{array}$ & 6111 & 0.07 & $\begin{array}{r}<0.3 \\
1\end{array}$ & $\begin{array}{r}<0.8 \\
2\end{array}$ & 2.7 & 47 & 143 & 1.1 & 21 & 0.80 & 0.42 & 628 & 9083 & 640 & $\begin{array}{r}<0.2 \\
6\end{array}$ & 11 & 24 & 0.17 & 11 & 223 \\
\hline $3 *$ & & 26 & $\begin{array}{r}<0.6 \\
0\end{array}$ & 3130 & 0.06 & 0.34 & $\begin{array}{r}<0.8 \\
4\end{array}$ & 1.6 & 50 & 194 & 0.96 & 17 & 0.90 & 0.49 & 675 & 9777 & 726 & $\begin{array}{r}<0.2 \\
5\end{array}$ & 4.3 & 13 & 0.06 & 4.5 & 191 \\
\hline $4 *$ & & 34 & $\begin{array}{r}<0.5 \\
3\end{array}$ & 6475 & $\begin{array}{r}<0.0 \\
5\end{array}$ & $\begin{array}{r}<0.3 \\
0\end{array}$ & $\begin{array}{r}<0.7 \\
6\end{array}$ & 2.6 & 45 & 117 & 0.66 & 17 & 0.75 & 0.53 & 491 & 6795 & 466 & $\begin{array}{r}<0.2 \\
6\end{array}$ & 3.9 & 18 & 0.09 & 9.0 & 164 \\
\hline $5^{*}$ & & 24 & $\begin{array}{r}<0.5 \\
8\end{array}$ & 3431 & $\begin{array}{r}<0.0 \\
6\end{array}$ & 0.35 & 0.86 & 1.9 & 47 & 238 & 1.6 & 15 & 0.81 & 0.33 & 938 & $\begin{array}{r}1514 \\
8\end{array}$ & $\begin{array}{r}128 \\
4\end{array}$ & $\begin{array}{r}<0.2 \\
5\end{array}$ & 5.2 & 14 & 0.07 & 4.4 & 286 \\
\hline $6^{*}$ & & 44 & $\begin{array}{r}<0.7 \\
1\end{array}$ & 4478 & $\begin{array}{r}<0.0 \\
7\end{array}$ & $\begin{array}{r}<0.4 \\
1\end{array}$ & 1.9 & 4.8 & 46 & 97 & 0.51 & 23 & $\begin{array}{r}<0.3 \\
6\end{array}$ & 0.36 & 385 & 5348 & 364 & $\begin{array}{r}<0.3 \\
8\end{array}$ & 7.0 & 13 & 0.37 & 9.4 & 129 \\
\hline $7 *$ & & 28 & $\begin{array}{r}<0.5 \\
9\end{array}$ & 5371 & $\begin{array}{r}<0.0 \\
7\end{array}$ & $\begin{array}{r}<0.3 \\
0\end{array}$ & $\begin{array}{r}<0.8 \\
4\end{array}$ & 2.2 & 49 & & 1.2 & 14 & 0.87 & 0.38 & 776 & $\begin{array}{r}1226 \\
9\end{array}$ & 970 & $\begin{array}{r}<0.2 \\
4\end{array}$ & 3.0 & 15 & 0.09 & 6.1 & 246 \\
\hline $8^{*}$ & & 28 & $\begin{array}{r}<0.5 \\
3\end{array}$ & 4700 & $\begin{array}{r}<0.0 \\
4\end{array}$ & $\begin{array}{r}<0.2 \\
6\end{array}$ & $\begin{array}{r}<0.7 \\
3\end{array}$ & 2.0 & 47 & & 0.72 & 19 & 0.81 & 0.26 & 597 & 8679 & 631 & $\begin{array}{r}<0.2 \\
6\end{array}$ & 6.3 & 16 & 0.07 & 6.7 & 191 \\
\hline $9 *$ & & 31 & $\begin{array}{r}<0.6 \\
3\end{array}$ & 5894 & 0.07 & $\begin{array}{r}<0.3 \\
4\end{array}$ & $\begin{array}{r}<0.8 \\
7\end{array}$ & 2.8 & & 163 & 0.65 & 18 & 0.48 & 0.28 & 555 & 8108 & 584 & $\begin{array}{r}<0.2 \\
9\end{array}$ & 6.1 & 19 & 0.10 & 8.5 & 181 \\
\hline $\begin{array}{l}10 \\
*\end{array}$ & & 29 & $\begin{array}{r}<0.3 \\
9\end{array}$ & 5118 & 0.06 & 0.56 & 0.71 & & 47 & 172 & 0.82 & 20 & 0.66 & 0.37 & 610 & 9076 & 656 & $\begin{array}{r}<0.1 \\
8\end{array}$ & 8.6 & 17 & 0.13 & 8.6 & 218 \\
\hline $\begin{array}{l}11 \\
*\end{array}$ & & 39 & 0.45 & 5190 & 0.04 & $\begin{array}{r}<0.2 \\
2\end{array}$ & 0.92 & 2.8 & 50 & 138 & 0.59 & 24 & 0.50 & 0.18 & 457 & 6520 & 466 & $\begin{array}{r}<0.1 \\
7\end{array}$ & 8.7 & 18 & 0.34 & 9.7 & 159 \\
\hline $\begin{array}{l}12 \\
*\end{array}$ & & 25 & 0.64 & 8389 & 0.05 & 0.30 & 0.47 & 4.2 & 46 & 182 & 0.72 & 16 & 0.43 & 0.29 & 658 & 9766 & 710 & $\begin{array}{r}<0.1 \\
7\end{array}$ & 9.0 & 28 & 0.20 & 14 & 256 \\
\hline $\begin{array}{l}13 \\
*\end{array}$ & & 24 & 0.37 & 8705 & 0.04 & $\begin{array}{r}<0.2 \\
0\end{array}$ & $\begin{array}{r}<0.5 \\
0\end{array}$ & 4.6 & 46 & 161 & 0.81 & 18 & 0.42 & 0.17 & 588 & 8543 & 610 & $\begin{array}{r}<0.1 \\
5\end{array}$ & 13 & 33 & 0.28 & 18 & 228 \\
\hline $\begin{array}{l}14 \\
*\end{array}$ & & 19 & 0.46 & 8791 & $\begin{array}{r}<0.0 \\
3\end{array}$ & $\begin{array}{r}<0.1 \\
8\end{array}$ & 0.48 & 5.0 & 42 & 120 & 0.50 & 18 & 0.43 & 0.17 & 544 & 8255 & 597 & $\begin{array}{r}<0.1 \\
6\end{array}$ & 13 & 37 & 0.44 & 21 & 225 \\
\hline $\begin{array}{l}15 \\
*\end{array}$ & & 19 & 0.41 & 9664 & $\begin{array}{r}<0.0 \\
3\end{array}$ & 0.22 & 0.54 & 5.5 & 43 & 100 & 0.71 & 20 & 0.64 & 0.13 & 530 & 7541 & 511 & $\begin{array}{r}<0.1 \\
5\end{array}$ & 17 & 47 & 0.56 & 30 & 209 \\
\hline $\begin{array}{l}16 \\
*\end{array}$ & & 18 & 0.39 & $\begin{array}{r}1113 \\
5\end{array}$ & $\begin{array}{r}<0.0 \\
3\end{array}$ & $\begin{array}{r}<0.1 \\
6\end{array}$ & 0.63 & 6.9 & 42 & 100 & 0.46 & 21 & 0.27 & 0.11 & 444 & 5980 & 390 & $\begin{array}{r}<0.1 \\
6\end{array}$ & 20 & 59 & 0.76 & 39 & 170 \\
\hline $\begin{array}{l}17 \\
*\end{array}$ & & 15 & 0.66 & $\begin{array}{r}1196 \\
4\end{array}$ & $\begin{array}{r}<0.0 \\
4\end{array}$ & $\begin{array}{r}<0.1 \\
8\end{array}$ & $\begin{array}{r}<0.4 \\
7\end{array}$ & 7.9 & 42 & 96 & 0.46 & 24 & 0.27 & $\begin{array}{r}<0.0 \\
8\end{array}$ & 410 & 5453 & 359 & $\begin{array}{r}<0.1 \\
7\end{array}$ & 26 & 75 & 0.99 & 50 & 159 \\
\hline $\begin{array}{l}18 \\
*\end{array}$ & & 14 & 0.50 & $\begin{array}{r}1240 \\
4\end{array}$ & 0.03 & 0.16 & $\begin{array}{r}<0.4 \\
5\end{array}$ & 8.6 & 41 & 102 & 0.56 & 26 & $\begin{array}{r}<0.1 \\
9\end{array}$ & 0.12 & 440 & 5905 & 393 & $\begin{array}{r}<0.1 \\
7\end{array}$ & 28 & 80 & 1.00 & 53 & 174 \\
\hline 19 & & 14 & 0.63 & 1421 & $<0.0$ & $<0.1$ & 0.69 & 12 & 39 & 86 & 0.50 & 44 & 0.21 & 0.10 & 323 & 4219 & 277 & $<0.1$ & 35 & 93 & 1.26 & 76 & 128 \\
\hline
\end{tabular}




\begin{tabular}{|c|c|c|c|c|c|c|c|c|c|c|c|c|c|c|c|c|c|c|c|c|c|c|}
\hline * & & & 5 & 3 & 5 & & & & & & & & & & & & 5 & & & & & \\
\hline 20 & 27 & $\begin{array}{r}<0.7 \\
6\end{array}$ & 1264 & $\begin{array}{r}<0.0 \\
6\end{array}$ & $\begin{array}{r}<0.2 \\
9\end{array}$ & 2.2 & 1.3 & 48 & 103 & 2.5 & 20 & $\begin{array}{r}<0.4 \\
3\end{array}$ & 0.51 & 682 & 8853 & 640 & $\begin{array}{r}<0.4 \\
3\end{array}$ & 8.0 & 12 & 0.12 & 4.8 & 157 \\
\hline 21 & 36 & $\begin{array}{r}<0.7 \\
2\end{array}$ & 5262 & $\begin{array}{r}<0.0 \\
8\end{array}$ & $\begin{array}{r}<0.3 \\
1\end{array}$ & 2.8 & 19 & 51 & 126 & 12 & 24 & 0.38 & 0.18 & 619 & 7943 & 578 & $\begin{array}{r}<0.4 \\
1\end{array}$ & 14 & 21 & 0.27 & 21 & 151 \\
\hline 22 & 34 & $\begin{array}{r}<0.6 \\
6\end{array}$ & 6221 & $\begin{array}{r}<0.0 \\
7\end{array}$ & $\begin{array}{r}<0.2 \\
7\end{array}$ & 1.1 & 35 & 63 & 210 & 17 & 32 & 0.51 & 0.37 & 648 & 8310 & 649 & $\begin{array}{r}<0.3 \\
7\end{array}$ & 20 & 29 & 0.20 & 23 & 166 \\
\hline 23 & 22 & $\begin{array}{r}<0.7 \\
5\end{array}$ & 1963 & $\begin{array}{r}<0.0 \\
7\end{array}$ & 0.39 & 3.4 & 2.3 & 44 & 129 & 4.7 & 22 & 0.48 & 0.35 & $\begin{array}{r}107 \\
0\end{array}$ & $\begin{array}{r}1548 \\
7\end{array}$ & $\begin{array}{r}152 \\
3\end{array}$ & $\begin{array}{r}<0.4 \\
2\end{array}$ & 12 & 16 & 0.49 & 6.9 & 262 \\
\hline 24 & 22 & $\begin{array}{r}<0.7 \\
3\end{array}$ & 1800 & $\begin{array}{r}<0.0 \\
8\end{array}$ & $\begin{array}{r}<0.3 \\
1\end{array}$ & $<1.0$ & 1.6 & 49 & 313 & 2.8 & 16 & 0.54 & $\begin{array}{r}<0.1 \\
9\end{array}$ & 900 & $\begin{array}{r}1375 \\
0\end{array}$ & $\begin{array}{r}119 \\
7\end{array}$ & $\begin{array}{r}<0.4 \\
1\end{array}$ & 4.2 & 10 & 0.03 & 3.0 & 197 \\
\hline 25 & 20 & $\begin{array}{r}<0.9 \\
1\end{array}$ & 2090 & $\begin{array}{r}<0.1 \\
0\end{array}$ & $\begin{array}{r}<0.4 \\
3\end{array}$ & $<1.3$ & 2.7 & 52 & 203 & 4.0 & 18 & $\begin{array}{r}<0.4 \\
3\end{array}$ & $\begin{array}{r}<0.2 \\
9\end{array}$ & $\begin{array}{r}117 \\
0\end{array}$ & $\begin{array}{r}1658 \\
2\end{array}$ & $\begin{array}{r}142 \\
8\end{array}$ & $\begin{array}{r}<0.5 \\
2\end{array}$ & 9.0 & 17 & 0.07 & 4.1 & 306 \\
\hline 26 & 20 & $\begin{array}{r}<0.8 \\
8\end{array}$ & 1587 & $\begin{array}{r}<0.1 \\
0\end{array}$ & $\begin{array}{r}<0.4 \\
2\end{array}$ & $<1.3$ & 4.0 & 86 & 866 & 5.9 & 18 & $\begin{array}{r}<0.4 \\
3\end{array}$ & $\begin{array}{r}<0.2 \\
8\end{array}$ & 850 & $\begin{array}{r}1316 \\
0\end{array}$ & $\begin{array}{r}106 \\
3\end{array}$ & $\begin{array}{r}<0.5 \\
1\end{array}$ & 5.0 & 14 & 0.03 & 3.0 & 279 \\
\hline 27 & 23 & $\begin{array}{r}<0.8 \\
0\end{array}$ & 1132 & $\begin{array}{r}<0.0 \\
8\end{array}$ & 0.44 & $<1.0$ & 1.8 & 52 & 217 & & 18 & 0.59 & 0.23 & 737 & 9496 & 669 & $\begin{array}{r}<0.4 \\
1\end{array}$ & 5.5 & 10 & $\begin{array}{r}<0.0 \\
3\end{array}$ & 2.6 & 168 \\
\hline 28 & 32 & $\begin{array}{r}<0.8 \\
4\end{array}$ & 4875 & $\begin{array}{r}<0.0 \\
8\end{array}$ & $\begin{array}{r}<0.3 \\
4\end{array}$ & 2.2 & 72 & 80 & 305 & 16 & 25 & 0.46 & 0.45 & 707 & 9445 & 714 & $\begin{array}{r}<0.4 \\
3\end{array}$ & 14 & 27 & 0.19 & 18 & 189 \\
\hline 29 & 22 & $\begin{array}{r}<0.7 \\
9\end{array}$ & 650 & $\begin{array}{r}<0.0 \\
7\end{array}$ & $\begin{array}{r}<0.3 \\
4\end{array}$ & $<1.1$ & 3.1 & 109 & 791 & 2.5 & 20 & 0.75 & 0.34 & 652 & 9704 & 724 & $\begin{array}{r}<0.3 \\
9\end{array}$ & 4.1 & 13 & 0.09 & 2.9 & 187 \\
\hline 30 & 31 & $\begin{array}{r}<0.8 \\
0\end{array}$ & 7305 & $\begin{array}{r}<0.0 \\
8\end{array}$ & $\begin{array}{r}<0.3 \\
6\end{array}$ & 1.7 & 106 & & 416 & 28 & 27 & 0.55 & 0.32 & 819 & $\begin{array}{r}1167 \\
8\end{array}$ & 982 & $\begin{array}{r}<0.4 \\
1\end{array}$ & 20 & 36 & 0.22 & 29 & 228 \\
\hline 31 & 26 & $\begin{array}{r}<0.8 \\
5\end{array}$ & 689 & 0.07 & $\begin{array}{r}<0.4 \\
4\end{array}$ & 3.3 & 6.3 & & 581 & 2.3 & 17 & 0.57 & 0.39 & 531 & 7668 & 554 & $\begin{array}{r}<0.4 \\
5\end{array}$ & 4.0 & 13 & 0.03 & 2.6 & 148 \\
\hline 32 & 25 & $\begin{array}{r}<0.8 \\
9\end{array}$ & 654 & $\begin{array}{r}<0.0 \\
7\end{array}$ & $\begin{array}{r}<0.4 \\
7\end{array}$ & $<1.2$ & 8.6 & 120 & 800 & 1.8 & 16 & 0.86 & 0.59 & 635 & 8378 & 594 & $\begin{array}{r}<0.4 \\
8\end{array}$ & 2.5 & 12 & $\begin{array}{r}<0.0 \\
2\end{array}$ & 1.0 & 171 \\
\hline 33 & 30 & $\begin{array}{r}<0.7 \\
9\end{array}$ & 1414 & $\begin{array}{r}<0.0 \\
8\end{array}$ & $\begin{array}{r}<0.3 \\
5\end{array}$ & 1.1 & & 85 & 562 & 1.3 & 19 & 0.84 & 0.43 & 526 & 7285 & 521 & $\begin{array}{r}<0.4 \\
0\end{array}$ & 9.7 & 13 & 0.08 & 5.4 & 167 \\
\hline 34 & 42 & $\begin{array}{r}<0.8 \\
5\end{array}$ & 6051 & $\begin{array}{r}<0.0 \\
9\end{array}$ & $\begin{array}{r}<0.3 \\
9\end{array}$ & 1.3 & 25 & 135 & 726 & 1.4 & 24 & 0.82 & 0.34 & 440 & 6635 & 443 & $\begin{array}{r}<0.4 \\
4\end{array}$ & 11 & 26 & 0.13 & 10 & 164 \\
\hline 35 & 14 & $\begin{array}{r}<0.9 \\
2\end{array}$ & 1101 & $\begin{array}{r}<0.0 \\
9\end{array}$ & $\begin{array}{r}<0.3 \\
9\end{array}$ & $<1.2$ & 6.4 & 115 & $\begin{array}{r}124 \\
6\end{array}$ & 2.6 & 14 & 0.68 & 0.41 & 882 & $\begin{array}{r}1432 \\
3\end{array}$ & $\begin{array}{r}110 \\
6\end{array}$ & $\begin{array}{r}<0.5 \\
0\end{array}$ & 0.9 & 16 & 0.03 & $\begin{array}{r}0.6 \\
8\end{array}$ & 334 \\
\hline 36 & 24 & $\begin{array}{r}<0.9 \\
2 \\
\end{array}$ & 837 & $\begin{array}{r}<0.0 \\
9 \\
\end{array}$ & $\begin{array}{r}<0.4 \\
0 \\
\end{array}$ & 1.5 & 5.1 & 105 & 581 & 4.1 & 17 & 0.59 & 0.30 & 714 & $\begin{array}{r}1041 \\
0 \\
\end{array}$ & 869 & $\begin{array}{r}<0.5 \\
1 \\
\end{array}$ & 4.8 & 12 & $\begin{array}{r}<0.0 \\
4 \\
\end{array}$ & 1.8 & 210 \\
\hline
\end{tabular}

\section{Appendix 3 (cont.)}

\begin{tabular}{|c|c|c|c|c|c|c|c|c|c|c|c|c|c|c|c|c|c|c|c|c|c|c|c|}
\hline \multirow[t]{2}{*}{$\#$} & Sample & & $\mathrm{Mn}$ & $\mathrm{Fe}$ & Co & $\mathrm{Ni}$ & $\mathrm{Zn}$ & $\mathrm{Ga}$ & $\mathrm{Ge}$ & $\mathrm{Se}$ & Мo & $\mathrm{Ag}$ & $\mathrm{Cd}$ & In & $\mathrm{Sn}$ & $\mathrm{Sb}$ & $\mathrm{Te}$ & W & $\mathrm{Au}$ & $\mathrm{Hg}$ & $\mathrm{Tl}$ & $\mathrm{Pb}$ & $\mathrm{Bi}$ \\
\hline & & $\begin{array}{l}\mu \mathrm{g} / \\
\mathrm{g}\end{array}$ & $\mu \mathrm{g} / \mathrm{g}$ & $\mu \mathrm{g} / \mathrm{g}$ & $\mu \mathrm{g} / \mathrm{g}$ & $\mu \mathrm{g} / \mathrm{g}$ & $\mu \mathrm{g} / \mathrm{g}$ & $\mu \mathrm{g} / \mathrm{g}$ & $\begin{array}{l}\mu \mathrm{g} / \\
\mathrm{g}\end{array}$ & $\begin{array}{l}\mu \mathrm{g} / \\
\mathrm{g}\end{array}$ & $\mu \mathrm{g} / \mathrm{g}$ & $\mu \mathrm{g} / \mathrm{g}$ & $\mu \mathrm{g} / \mathrm{g}$ & $\mu \mathrm{g} / \mathrm{g}$ & $\begin{array}{l}\mu \mathrm{g} / \\
\mathrm{g}\end{array}$ & $\mu \mathrm{g} / \mathrm{g}$ & $\begin{array}{l}\mu \mathrm{g} / \\
\mathrm{g}\end{array}$ & $\mu \mathrm{g} / \mathrm{g}$ & $\begin{array}{l}\mu \mathrm{g} / \\
\mathrm{g}\end{array}$ & $\begin{array}{l}\mu \mathrm{g} / \\
\mathrm{g}\end{array}$ & $\mu \mathrm{g} / \mathrm{g}$ & $\begin{array}{l}\mu \mathrm{g} / \\
\mathrm{g}\end{array}$ & $\begin{array}{l}\mu \mathrm{g} / \\
\mathrm{g}\end{array}$ \\
\hline & $\mathrm{MN}$ & & & & $<0.0$ & $<0.1$ & & & & & & & & & & & & $<0.3$ & & & & & 167 \\
\hline 1 & $01-12$ & 38 & 0.84 & 8502 & 5 & 9 & 2.0 & 0.77 & 32 & 106 & 0.33 & 68 & 0.98 & 0.41 & 310 & 6794 & 37 & 5 & 17 & 43 & 0.10 & 4.8 & 8 \\
\hline 2 & luzonit & 32 & $<0.5$ & 3019 & 0.05 & $<0.2$ & 18 & 1.0 & 29 & 80 & 0.69 & 62 & 1.2 & 0.41 & 321 & 7848 & 50 & $<0.3$ & 5.9 & 16 & 0.19 & 4.5 & 851 \\
\hline
\end{tabular}




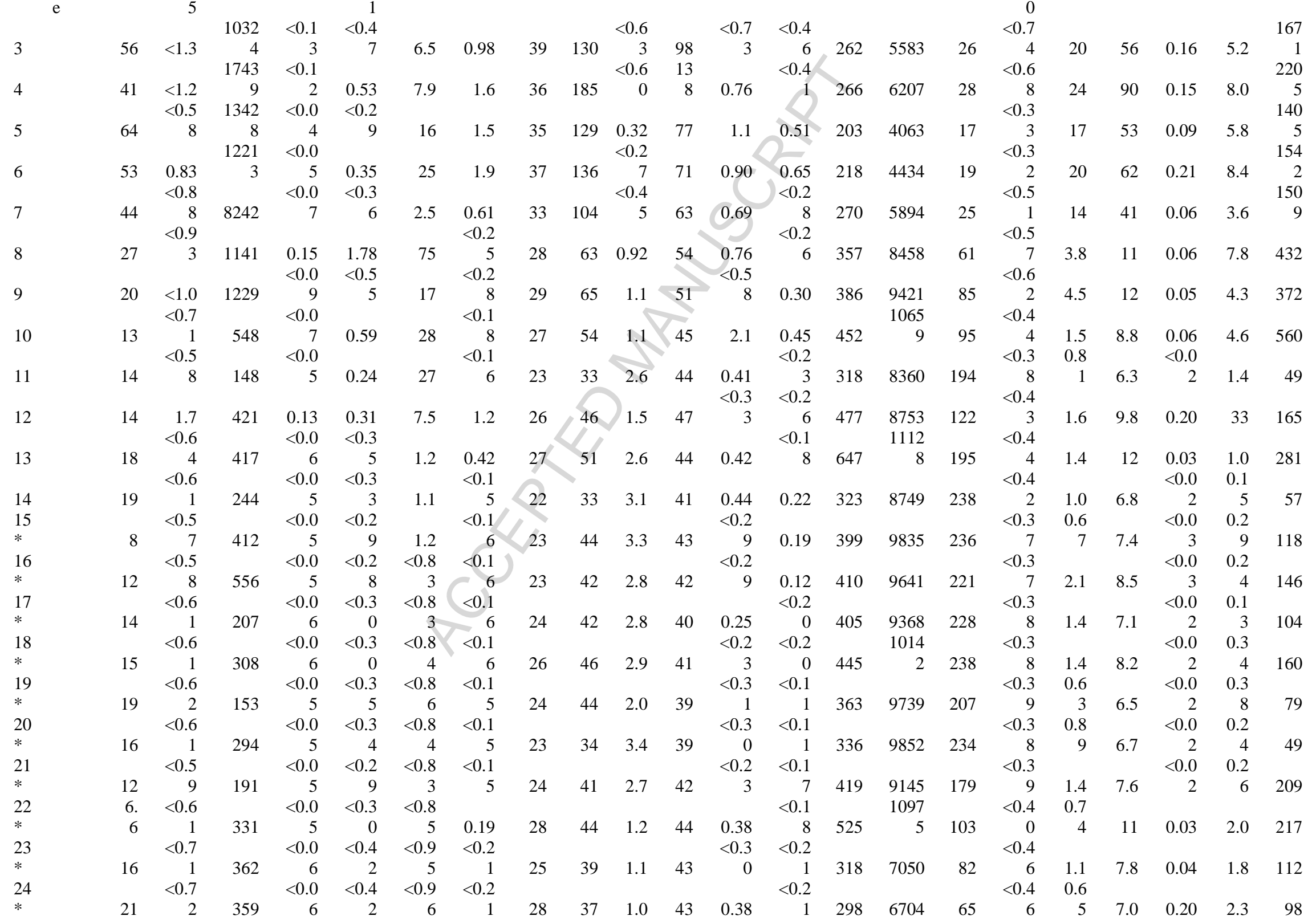




\begin{tabular}{|c|c|c|c|c|c|c|c|c|c|c|c|c|c|c|c|c|c|c|c|c|c|c|}
\hline 25 & & $<0.6$ & & $<0.0$ & $<0.3$ & $<0.7$ & $<0.1$ & & & & & & & & & & $<0.3$ & 0.6 & & $<0.0$ & 0.1 & \\
\hline$*$ & 21 & 0 & 410 & 5 & 2 & 8 & 6 & 24 & 36 & 1.1 & 44 & 0.49 & 0.18 & 270 & 6583 & 66 & 7 & 2 & 6.1 & 2 & 6 & 105 \\
\hline 26 & & $<0.6$ & & $<0.0$ & $<0.3$ & $<0.8$ & $<0.1$ & & & & & & & & & & $<0.3$ & & & & 0.2 & \\
\hline$*$ & 25 & 1 & 767 & 6 & 3 & 0 & 6 & 27 & 41 & 0.72 & 46 & 0.33 & 0.19 & 279 & 6039 & 40 & 8 & 1.6 & 7.6 & 0.02 & 9 & 259 \\
\hline 27 & & $<0.5$ & & $<0.0$ & $<0.2$ & & $<0.1$ & & & & & $<0.2$ & $<0.1$ & 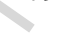 & & & $<0.3$ & & & $<0.0$ & 0.4 & \\
\hline$*$ & 30 & 9 & 1125 & 6 & 6 & 1.0 & 6 & 28 & 45 & 0.43 & 47 & 4 & & 256 & 5572 & 28 & 6 & 1.7 & 9.3 & 2 & 2 & 394 \\
\hline 28 & & & 1096 & & & & & & & & 10 & & & & & & & & & & & 138 \\
\hline$*$ & 60 & 0.70 & 7 & 0.12 & 2.49 & 323 & 3.1 & 38 & 106 & 0.45 & 1 & 0.77 & 0.35 & 199 & 4038 & 18 & 0.44 & 17 & 73 & 0.23 & 16 & 0 \\
\hline
\end{tabular}

Appendix 3 (cont.)

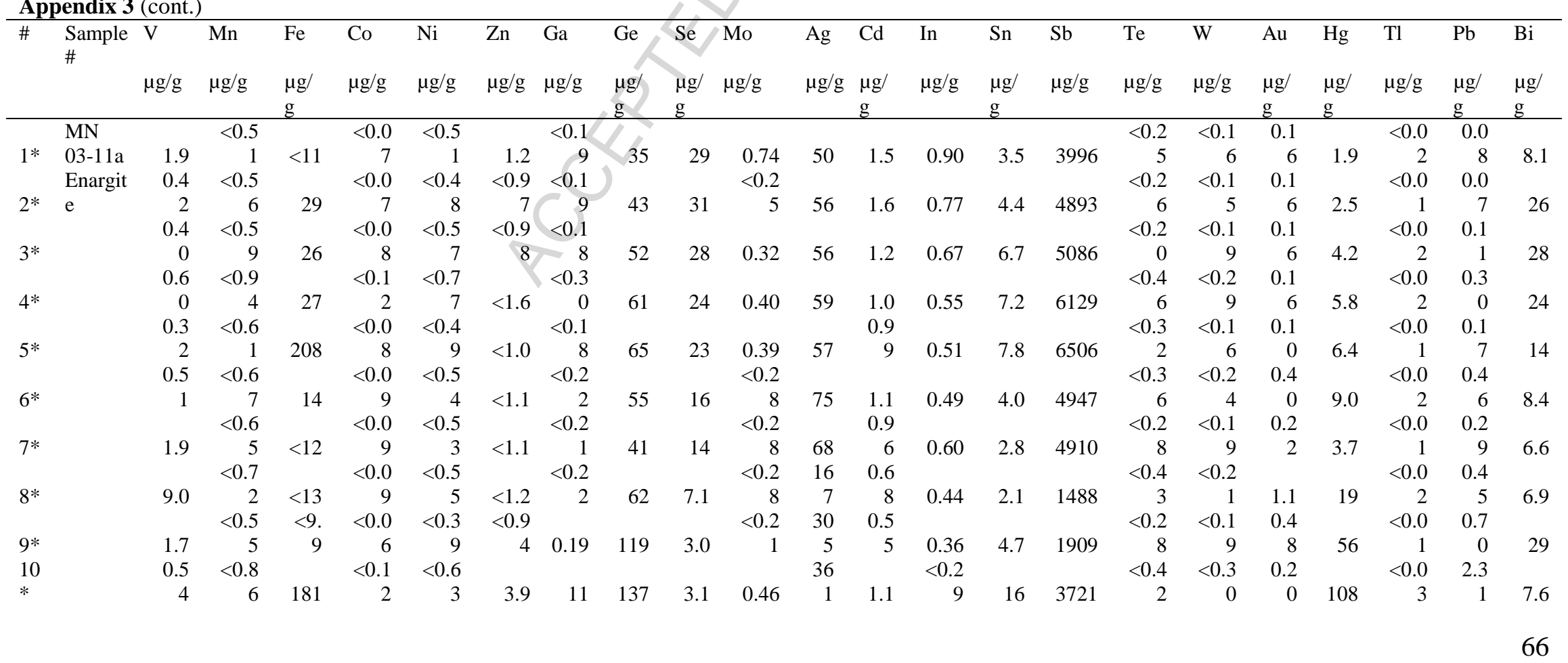




\begin{tabular}{|c|c|c|c|c|c|c|c|c|c|c|c|c|c|c|c|c|c|c|c|c|c|c|}
\hline & & $<0.8$ & & $<0.0$ & $<0.5$ & & & & & & & 0.9 & & & 1660 & & $<0.2$ & 0.1 & & $<0.0$ & 0.7 & \\
\hline \multirow{2}{*}{11} & 7.9 & 2 & $<14$ & 9 & 8 & $<1.4$ & 0.25 & 41 & 99 & 2.3 & 45 & 0 & 0.48 & 65 & 7 & 0.70 & 7 & 4 & 12 & 3 & 7 & 1.2 \\
\hline & 0.5 & $<0.5$ & $<9$ & $<0.0$ & $<0.3$ & $<0.8$ & $<0.1$ & & & & & 0.8 & & & 1783 & $<0.2$ & $<0.1$ & 0.0 & & $<0.0$ & 0.6 & 0.3 \\
\hline \multirow[t]{2}{*}{12} & 4 & 2 & 3 & 6 & 6 & 6 & 5 & 38 & 148 & 0.38 & 98 & 2 & 0.54 & 41 & 6 & 0 & 8 & 7 & 8.7 & 1 & 3 & 7 \\
\hline & & $<0.5$ & $<9$ & $<0.0$ & $<0.3$ & $<0.8$ & $<0.1$ & & & & 32 & & & & 2821 & $<0.2$ & $<0.1$ & 0.2 & & $<0.0$ & 0.4 & \\
\hline \multirow[t]{2}{*}{13} & 1.5 & 3 & 4 & 6 & 6 & 8 & 5 & 33 & 118 & 1.4 & 3 & 1.1 & 0.56 & 63 & 0 & 0 & 7 & 0 & 38 & 1 & 1 & 1.4 \\
\hline & & $<0.5$ & & $<0.0$ & $<0.3$ & $<0.8$ & $<0.1$ & & & & & 0.9 & & & 4110 & $<0.2$ & $<0.1$ & 0.2 & & $<0.0$ & 0.5 & 10. \\
\hline \multirow[t]{2}{*}{14} & 123 & 3 & 106 & 5 & 7 & 9 & 6 & 38 & 123 & 4.7 & 74 & 2 & 0.40 & 179 & 9 & 5 & 6 & 9 & 16 & 1 & 5 & 0 \\
\hline & & $<0.5$ & & $<0.0$ & $<0.3$ & $<0.9$ & $<0.1$ & & & & & 0.8 & . & & 1288 & $<0.2$ & $<0.1$ & 0.3 & & $<0.0$ & 0.6 & \\
\hline \multirow[t]{2}{*}{15} & 16 & 8 & 60 & 6 & 7 & 5 & 7 & 41 & 106 & 1.2 & 73 & 2 & 0.34 & 45 & 8 & 7 & 8 & 0 & 5.9 & 1 & 2 & 3.8 \\
\hline & & $<0.6$ & 130 & & $<0.4$ & $<0.9$ & $<0.1$ & & & & & 0.5 & & & 3127 & $<0.2$ & $<0.2$ & 0.6 & & $<0.0$ & 0.9 & \\
\hline \multirow[t]{2}{*}{16} & 51 & 0 & 3 & 0.19 & 5 & 7 & 6 & 49 & 136 & 3.0 & $r_{1}$ & 5 & 0.40 & 120 & 2 & 3 & 0 & 5 & 16 & 2 & 5 & 37 \\
\hline & & $<0.5$ & & $<0.0$ & $<0.3$ & $<0.9$ & $<0.1$ & & & & & 0.5 & & & 2120 & $<0.3$ & $<0.2$ & 0.3 & & $<0.0$ & 0.5 & \\
\hline \multirow[t]{2}{*}{17} & 21 & 9 & 562 & 8 & 9 & 5 & 6 & 37 & 101 & 1.9 & 74 & 5 & 0.44 & 60 & 7 & 1 & 0 & 1 & 7.5 & 1 & 9 & 3.0 \\
\hline & & $<0.5$ & & $<0.0$ & $<0.3$ & & $<0.1$ & & & & & 0.4 & & & 2242 & $<0.2$ & $<0.1$ & 0.8 & & $<0.0$ & 0.6 & \\
\hline \multirow[t]{2}{*}{18} & 43 & 8 & 352 & 6 & 8 & 1.2 & 7 & 41 & 108 & 1.8 & 81 & 6 & 0.47 & 75 & 5 & 1 & 8 & 5 & 19 & 1 & 8 & 13 \\
\hline & & $<0.6$ & & & $<0.4$ & & $<0.1$ & & & & & 0.9 & & & 1196 & $<0.2$ & $<0.2$ & 0.3 & & $<0.0$ & 1.6 & \\
\hline \multirow[t]{2}{*}{19} & 23 & 3 & 991 & 0.14 & 0 & 1.1 & 7 & 45 & 103 & 2.7 & 78 & 2 & 0.45 & 41 & 0 & 4 & 2 & 2 & 6.9 & 2 & 4 & 8.1 \\
\hline & & $<0.5$ & & $<0.0$ & $<0.3$ & $<0.8$ & $<0.1$ & & & 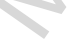 & & 0.6 & & & 3109 & $<0.2$ & $<0.1$ & 0.3 & & $<0.0$ & 0.2 & \\
\hline \multirow[t]{2}{*}{20} & 39 & 6 & 59 & 6 & 9 & 5 & 5 & 45 & 116 & 0.52 & 81 & 9 & 0.24 & 78 & 1 & 6 & 7 & 7 & 11 & 1 & 4 & 50 \\
\hline & & & & $<0.0$ & $<0.3$ & $<0.9$ & $<0.1$ & & & & 11 & & & & 1825 & $<0.2$ & $<0.2$ & & & $<0.0$ & 0.8 & \\
\hline \multirow[t]{2}{*}{21} & 3.7 & 0.61 & 13 & 6 & 6 & 6 & 9 & 48 & 108 & 0.93 & 2 & 1.3 & 0.80 & 75 & 6 & 4 & 5 & 1.1 & 82 & 1 & 9 & 2.2 \\
\hline & 0.3 & $<0.5$ & $<9$ & $<0.0$ & $<0.3$ & $<0.8$ & $<0.1$ & & 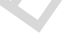 & & & & & & 2022 & & $<0.2$ & 0.5 & & $<0.0$ & 0.2 & \\
\hline \multirow[t]{2}{*}{22} & 3 & 4 & 2 & 6 & 5 & 4 & 7 & 48 & 121 & 1.1 & 63 & 1.1 & 0.50 & 79 & 9 & 0.55 & 4 & 8 & 20 & 2 & 5 & 1.2 \\
\hline & & & & $<0.0$ & $<0.3$ & & $<0.1$ & & & & & 0.9 & & & 3190 & $<0.2$ & $<0.2$ & 0.7 & & $<0.0$ & 0.3 & \\
\hline \multirow[t]{2}{*}{23} & 6.0 & 0.56 & 19 & 6 & 1 & 1.1 & 6 & & 161 & 1.1 & 51 & 1 & 0.58 & 99 & 1 & 1 & 0 & 4 & 14 & 1 & 4 & 12 \\
\hline & & $<0.5$ & & $<0.0$ & $<0.3$ & $<0.8$ & 0.1 & & & & & & & & 3372 & $<0.2$ & $<0.2$ & 0.3 & & & 0.2 & \\
\hline \multirow[t]{2}{*}{24} & 4.7 & 7 & 32 & 6 & 5 & 3 & 6 & 46 & 169 & 1.6 & 48 & 1.1 & 0.50 & 96 & 8 & 0 & 2 & 2 & 12 & 0.01 & 6 & 18 \\
\hline & & $<0.5$ & $<8$ & $<0.0$ & $<0.3$ & $<0.8$ & $<0.1$ & & & & & 0.7 & & & 2360 & & $<0.2$ & 0.1 & & $<0.0$ & 0.1 & 0.7 \\
\hline \multirow[t]{2}{*}{25} & 25 & 2 & 4 & 6 & 3 & 0 & 6 & 37 & 157 & 3.2 & 39 & 8 & 0.33 & 85 & 8 & 0.45 & 2 & 9 & 15 & 1 & 4 & 8 \\
\hline & 0.4 & $<0.5$ & $<8$ & $<0.0$ & $<0.3$ & $<0.8$ & $<0.1$ & & & & & 0.6 & & & 1609 & $<0.2$ & $<0.2$ & 0.2 & & $<0.0$ & 0.1 & \\
\hline 26 & 0 & 5 & 5 & 5 & 0 & 0 & 6 & 46 & 124 & 1.2 & 45 & 8 & 0.28 & 53 & 3 & 5 & 1 & 1 & 12 & 2 & 2 & 1.7 \\
\hline & 0.3 & $<0.6$ & $<9$ & $<0.0$ & $<0.3$ & $<0.8$ & $<0.1$ & & & $<0.2$ & & 0.9 & & & 1031 & $<0.1$ & $<0.2$ & 0.7 & & $<0.0$ & 0.2 & 0.8 \\
\hline 27 & 9 & 2 & 2 & 5 & 7 & 7 & 8 & 53 & 94 & 0 & 33 & 0 & 0.45 & 38 & 4 & 9 & 5 & 8 & 14 & 1 & 2 & 3 \\
\hline & & $<0.6$ & & & $<0.3$ & $<0.8$ & $<0.1$ & & & & & 0.8 & & & 2960 & $<0.2$ & $<0.2$ & 0.2 & & $<0.0$ & 0.2 & \\
\hline 28 & 6.5 & 0 & 34 & 0.06 & 3 & 5 & 7 & 45 & 161 & 1.4 & 51 & 7 & 0.36 & 84 & 9 & 6 & 5 & 4 & 15 & 1 & 1 & 16 \\
\hline & & $<0.5$ & & $<0.0$ & $<0.3$ & $<0.8$ & $<0.1$ & & & & & 0.6 & & & 3075 & $<0.2$ & $<0.2$ & 0.7 & & $<0.0$ & 0.3 & \\
\hline 29 & 6.3 & 9 & 29 & 6 & 5 & 2 & 7 & 46 & 167 & 0.65 & 51 & 5 & 0.24 & 85 & 5 & 3 & 4 & 4 & 13 & 1 & 1 & 19 \\
\hline & & $<0.5$ & & $<0.0$ & $<0.3$ & $<0.7$ & $<0.1$ & & & & & 0.7 & & & 2959 & $<0.2$ & $<0.2$ & 0.2 & & $<0.0$ & 0.2 & \\
\hline 30 & 3.7 & 2 & 35 & 5 & 3 & 4 & 5 & 45 & 166 & 0.75 & 44 & 2 & 0.29 & 70 & 6 & 0 & 0 & 4 & 8.4 & 1 & 7 & 26 \\
\hline & & $<0.5$ & $<8$ & $<0.0$ & $<0.3$ & $<0.8$ & $<0.1$ & & & & & 0.8 & & & 2465 & & $<0.2$ & 0.2 & & $<0.0$ & 0.1 & \\
\hline 31 & 35 & 8 & 7 & 5 & 5 & 1 & 7 & 41 & 173 & 1.6 & 48 & 2 & 0.37 & 78 & 5 & 0.24 & 3 & 2 & 18 & 2 & 4 & 1.1 \\
\hline & 0.6 & $<0.5$ & $<8$ & $<0.0$ & $<0.3$ & $<0.7$ & $<0.1$ & & & & & 0.7 & & & 1720 & & $<0.2$ & 0.2 & & $<0.0$ & 0.1 & \\
\hline 32 & 0 & 6 & 6 & 5 & 4 & 9 & 5 & 44 & 108 & 1.9 & 46 & 0 & 0.39 & 32 & 1 & 0.30 & 2 & 3 & 9.4 & 2 & 5 & 3.9 \\
\hline 33 & 0.1 & $<0.5$ & $<8$ & $<0.0$ & $<0.3$ & $<0.7$ & $<0.1$ & 52 & 56 & $<0.1$ & 10 & 0.6 & 0.21 & 14 & 8699 & $<0.1$ & $<0.2$ & 0.2 & 19 & $<0.0$ & 0.1 & 1.6 \\
\hline
\end{tabular}




\begin{tabular}{|c|c|c|c|c|c|c|c|c|c|c|c|c|c|c|c|c|c|c|c|c|c|c|}
\hline & 5 & 7 & 7 & 5 & 7 & 6 & 5 & & & 7 & 4 & 9 & & & & 8 & 2 & 0 & & 1 & 1 & \\
\hline & 0.2 & $<0.5$ & $<9$. & $<0.0$ & $<0.3$ & & $<0.1$ & & & $<0.2$ & 19 & 0.6 & & & & $<0.2$ & $<0.2$ & 0.2 & & $<0.0$ & 0.9 & \\
\hline \multirow[t]{2}{*}{34} & 4 & 9 & 3 & 6 & 3 & 1.3 & 6 & 64 & 36 & 0 & 8 & 3 & 0.29 & 10 & 5092 & 4 & 2 & 4 & 37 & 2 & 1 & 1.4 \\
\hline & & $<0.5$ & & $<0.0$ & $<0.3$ & $<0.8$ & $<0.1$ & & & & & 0.8 & & & 2535 & $<0.2$ & $<0.2$ & 0.9 & & $<0.0$ & 0.2 & \\
\hline \multirow[t]{2}{*}{35} & 9.9 & 8 & 23 & 5 & 1 & 0 & 6 & 53 & 113 & 0.90 & 67 & 7 & 0.24 & 104 & 9 & 2 & 2 & 8 & 22 & 1 & 1 & 5.0 \\
\hline & & $<0.5$ & & $<0.0$ & $<0.3$ & $<0.8$ & $<0.1$ & & & & & 0.6 & & & 2623 & $<0.1$ & $<0.2$ & & & $<0.0$ & 0.2 & \\
\hline \multirow[t]{2}{*}{36} & 25 & 8 & 34 & 5 & 0 & 2 & 6 & 45 & 123 & 0.71 & 68 & 9 & 0.18 & 89 & 0 & 8 & 4 & 2.2 & 25 & 2 & 8 & 8.7 \\
\hline & 0.1 & $<0.5$ & $<8$ & $<0.0$ & $<0.2$ & $<0.7$ & $<0.1$ & & & & & 0.5 & h & & & $<0.2$ & $<0.2$ & 0.1 & & $<0.0$ & 0.3 & 0.0 \\
\hline \multirow[t]{2}{*}{37} & 2 & 7 & 6 & 5 & 9 & 6 & 5 & 42 & 88 & 0.65 & 40 & 0 & 0.21 & 16 & 6102 & 8 & 2 & 4 & 4.9 & 1 & 3 & 6 \\
\hline & 0.1 & $<0.5$ & $<7$ & $<0.0$ & $<0.3$ & $<0.7$ & $<0.1$ & & & & & 0.9 & & & 1373 & $<0.2$ & $<0.2$ & 0.1 & & $<0.0$ & 0.3 & 0.8 \\
\hline \multirow[t]{2}{*}{38} & 0 & 1 & 7 & 4 & 1 & 2 & 3 & 45 & 96 & 0.31 & 39 & & 0.35 & 38 & 2 & 2 & 1 & 2 & 7.8 & 2 & 5 & 5 \\
\hline & & $<0.5$ & & $<0.0$ & $<0.3$ & $<0.7$ & $<0.1$ & & & & 17 & & & & 1346 & & $<0.2$ & & & $<0.0$ & 0.3 & \\
\hline 39 & 11 & 7 & 13 & 5 & 5 & 8 & 6 & 39 & 87 & 14 & 0 & 1.2 & 0.35 & 28 & 8 & 0.45 & 2 & 1.0 & 7.5 & 1 & 9 & 3.3 \\
\hline \multicolumn{23}{|c|}{ Appendix 3 (cont.) } \\
\hline \multirow[t]{4}{*}{ \# Sample \# } & $\mathrm{V}$ & $\mathrm{Mn}$ & $\mathrm{Fe}$ & Co & $\mathrm{Ni}$ & $\mathrm{Zn}$ & $\mathrm{Ga}$ & $\mathrm{Ge}$ & $\mathrm{Se}$ & Mo & $\mathrm{Ag}$ & $\mathrm{Cd}$ & In & $\mathrm{Sn}$ & $\mathrm{Sb}$ & $\mathrm{Te}$ & $\mathrm{W}$ & $\mathrm{Au}$ & $\mathrm{Hg}$ & $\mathrm{Tl}$ & $\mathrm{Pb}$ & $\mathrm{Bi}$ \\
\hline & $\mu \mathrm{g} /$ & $\mu \mathrm{g} / \mathrm{g}$ & $\mu \mathrm{g} / \mathrm{g}$ & $\mu \mathrm{g} / \mathrm{g}$ & $\mu \mathrm{g} /$ & $\mu \mathrm{g} /$ & $\mu \mathrm{g} /$ & $\mu \mathrm{g} / \mathrm{g}$ & $\mu \mathrm{g} /$ & $\mu \mathrm{g} / \mathrm{g}$ & $\mu \mathrm{g} / \mathrm{g}$ & $\mu \mathrm{g} / \mathrm{g}$ & $\mu \mathrm{g} / \mathrm{g}$ & $\mu \mathrm{g} /$ & $\mu \mathrm{g} /$ & $\mu \mathrm{g} / \mathrm{g}$ & $\mu \mathrm{g} / \mathrm{g}$ & $\mu \mathrm{g} /$ & $\mu \mathrm{g} /$ & $\mu \mathrm{g} /$ & $\mu \mathrm{g} / \mathrm{g}$ & $\mu \mathrm{g} /$ \\
\hline & $\mathrm{g}$ & & & & $\mathrm{g}$ & $\mathrm{g}$ & $\mathrm{g}$ & & $\mathrm{g}$ & & & & & $\mathrm{g}$ & g & & & o & $\sigma$ & $\mathrm{g}$ & & $\mathrm{g}$ \\
\hline & & 2 & $<0.0$ & $<0.0$ & & & & 125 & & $<0.0$ & 24 & & & & & & $<0.1$ & & & & 266 & \\
\hline \multirow{4}{*}{$\begin{array}{l}1 \mathrm{MN} \mathrm{01-12} \\
\text { pyrite/marcasit } \\
2 \mathrm{e}\end{array}$} & 0.57 & 1 & 2 & 9 & 9.0 & 7.9 & 5.1 & 5 & 180 & 9 & 2 & 0.20 & 0.07 & 1.2 & 16 & 0.13 & 3 & 13 & 105 & 62 & 7 & 14 \\
\hline & & 1 & $<0.1$ & $<0.5$ & & & & 128 & & $<0.5$ & & $<0.6$ & $<0.4$ & & & $<0.7$ & $<0.6$ & & & & & \\
\hline & 1.71 & 9 & 2 & 9 & 2.0 & 0.7 & 7.8 & 7 & 231 & 7 & 35 & 5 & 0 & 6.5 & 20 & 1 & 7 & 130 & 13 & 15 & 40 & 14 \\
\hline & & 2 & $<0.0$ & $<0.3$ & & & & & & & & $<0.3$ & $<0.2$ & & & $<0.4$ & $<0.4$ & & & & & \\
\hline \multirow[t]{2}{*}{3} & 0.43 & 1 & 8 & 6 & 2.3 & 2.7 & 5.7 & 357 & 11 & 6 & 65 & 9 & 4 & 0.79 & 13 & 3 & 4 & 13 & 15 & 8.6 & 395 & 5.5 \\
\hline & & 2 & $<0.0$ & $<0.1$ & & & & & & $<0.1$ & 14 & & & & & $<0.1$ & $<0.1$ & & & & 212 & \\
\hline \multirow[t]{2}{*}{4} & 0.55 & 1 & 2 & 4 & 8.8 & 14 & 5.2 & 943 & 186 & 1 & 6 & 0.19 & 0.12 & 0.60 & 5.9 & 6 & 4 & 5.5 & 74 & 45 & 9 & 5.0 \\
\hline & & 1 & $<0.0$ & & & & & & & $<0.5$ & & $<0.4$ & & & & $<0.5$ & $<0.5$ & & & & & \\
\hline \multirow[t]{2}{*}{5} & 0.94 & 9 & 9 & 0.42 & 3.3 & 0.4 & 5.2 & 57 & 212 & 1 & 33 & 3 & 0.47 & 1.6 & 1.8 & 8 & 8 & 174 & 8.4 & 13 & 62 & 9.3 \\
\hline & & 2 & $<0.0$ & $<0.3$ & & & & & & $<0.4$ & & $<0.3$ & $<0.2$ & & & $<0.4$ & $<0.4$ & & & & & \\
\hline \multirow[t]{2}{*}{6} & 0.52 & 0 & 7 & 1 & 4.0 & 6.6 & & 321 & 132 & 2 & 33 & 5 & 3 & 0.65 & 4.9 & 8 & 9 & 7.2 & 21 & 15 & 780 & 3.4 \\
\hline & & 2 & $<0.0$ & $<0.1$ & & & & 117 & & $<0.0$ & 12 & & & & & $<0.1$ & $<0.1$ & & & & 812 & \\
\hline \multirow[t]{2}{*}{7} & 0.63 & 1 & 2 & 0 & 12 & 11 & 8.3 & 5 & 285 & 9 & 7 & 1.20 & 0.68 & 0.57 & 7.4 & 4 & 3 & 4.4 & 135 & 131 & 1 & 7.4 \\
\hline & & 1 & $<0.0$ & $<0.0$ & & & & & & $<0.0$ & & & & & & & $<0.1$ & & & & 278 & \\
\hline \multirow[t]{2}{*}{8} & 0.72 & 9 & 2 & 9 & 1.6 & 0.71 & 6.0 & 475 & 209 & 8 & 89 & 0.18 & 0.14 & 0.73 & 16 & 0.18 & 2 & 3.6 & 134 & 17 & 6 & 3.0 \\
\hline & & 2 & $<0.0$ & $<0.0$ & & & & & & $<0.1$ & & & & & & $<0.1$ & $<0.1$ & & & & 228 & \\
\hline 9 & 0.69 & 0 & 2 & 9 & 1.2 & 0.59 & 3.2 & 481 & 109 & 2 & 37 & 0.17 & 0.07 & 0.53 & 6.5 & 5 & 5 & 1.4 & 41 & 17 & 8 & 0.91 \\
\hline 1 & & 1 & $<0.0$ & $<0.1$ & & & & & & $<0.1$ & & $<0.1$ & $<0.0$ & & & $<0.1$ & $<0.1$ & & & & 170 & \\
\hline 0 & 0.67 & 9 & 2 & 2 & 1.3 & 0.52 & 2.5 & 394 & 88 & 1 & 23 & 2 & 7 & 0.33 & 3.3 & 4 & 4 & 1.1 & 25 & 12 & 7 & 0.40 \\
\hline 1 & & 1 & $<0.0$ & $<0.0$ & & & & & & $<0.1$ & & $<0.1$ & $<0.0$ & & & $<0.1$ & $<0.1$ & & & & 124 & \\
\hline 1 & 0.55 & 9 & 2 & 8 & 0.80 & 0.22 & 4.3 & 236 & 148 & 0 & 67 & 2 & 7 & 0.41 & 6.5 & 5 & 3 & 6.2 & 52 & 9.6 & 5 & 1.6 \\
\hline
\end{tabular}

* - analyses along a core-to-rim profile. 